Florida International University FIU Digital Commons

$11-7-2012$

\title{
Sustainability Evaluation of Green Building Certification Systems
}

Martin Yuce

Florida International University, myuce001@fiu.edu

DOI: $10.25148 /$ etd.FI12120410

Follow this and additional works at: https://digitalcommons.fiu.edu/etd

\section{Recommended Citation}

Yuce, Martin, "Sustainability Evaluation of Green Building Certification Systems" (2012). FIU Electronic Theses and Dissertations. 769. https://digitalcommons.fiu.edu/etd/769

This work is brought to you for free and open access by the University Graduate School at FIU Digital Commons. It has been accepted for inclusion in FIU Electronic Theses and Dissertations by an authorized administrator of FIU Digital Commons. For more information, please contact dcc@fiu.edu. 


\title{
FLORIDA INTERNATIONAL UNIVERSITY
}

\author{
Miami, Florida
}

\section{SUSTAINABILITY EVALUATION OF GREEN BUILDING CERTIFICATION SYSTEMS}

\author{
A thesis submitted in partial fulfillment of \\ the requirements for the degree of \\ MASTER OF SCIENCE \\ in \\ CONSTRUCTION MANAGEMENT \\ by \\ Martin Yüce
}


To: Dean Amir Mirmiran

College of Engineering and Computing

This thesis, written by Martin Yüce, and entitled Sustainability Evaluation of Green Building Certification Systems, having been approved in respect to style and intellectual content, is referred to you for judgment.

We have read this thesis and recommend that it be approved.

Yimin Zhu

M. Emre Bayraktar

Wallied Orabi, Major Professor

Date of Defense: November 7, 2012

The thesis of Martin Yüce is approved.

$\begin{array}{r}\text { Dean Amir Mirmiran } \\ \text { College of Engineering and Computing } \\ \hline \begin{array}{r}\text { Dean Lakshmi N. Reddi } \\ \text { University Graduate School }\end{array}\end{array}$

Florida International University, 2012 
ABSTRACT OF THE THESIS

SUSTAINABILITY EVALUATION OF GREEN BUILDING CERTIFICATION

SYSTEMS

by

Martin Yüce

Florida International University, 2012

Miami, Florida

\section{Professor Wallied Orabi, Major Professor}

The attention on green building is driven by the desire to reduce a building's running cost over its entire life cycle. However, with the use of sustainable technologies and more environmentally friendly products in the building sector, the construction industry contributes significantly to sustainable actions of our society. Different certification systems have entered the market with the aim to measure a building's sustainability. However, each system uses its own set of criteria for the purpose of rating.

The primary goal of this study is to identify a comprehensive set of criteria for the measurement of building sustainability, and therefore to facilitate the comparison of existing rating methods. The collection and analysis of the criteria, identified through a comprehensive literature review, has led to the establishment of two additional categories besides the 3 pillars of sustainability. The comparative analyses presented in this thesis reveal strengths and weaknesses of the chosen green building certification systems LEED, BREEAM, and DGNB. 


\section{TABLE OF CONTENTS}

CHAPTER

PAGE

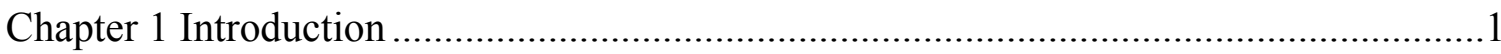

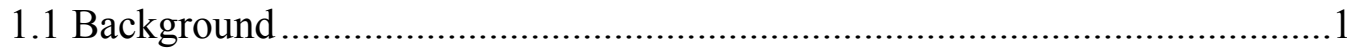

1.2 Problem Statement ................................................................................

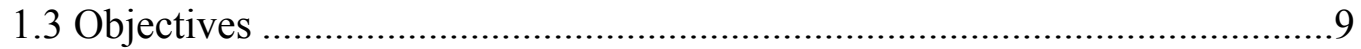

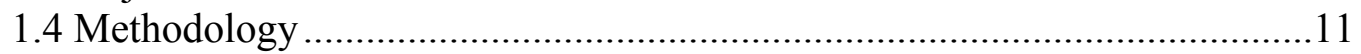

1.5 Thesis Organization ...............................................................................

Chapter 2 Literature Review ………………………….......................................15

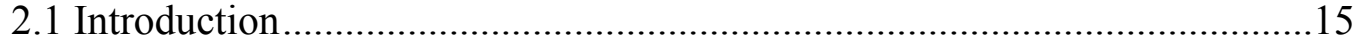

2.2 Political and Voluntary Organizations .......................................................

2.3 Industry and Academic Alliances ............................................................

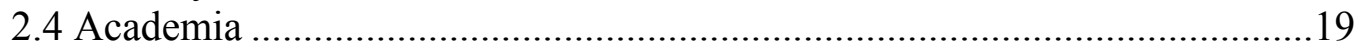

Chapter 3 Identifying Green Building Criteria ………..................................................21

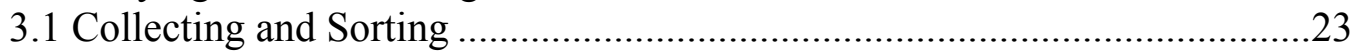

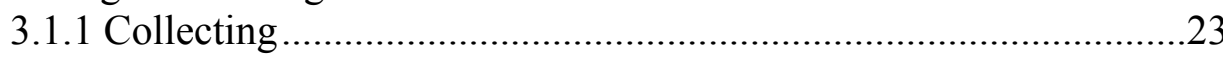

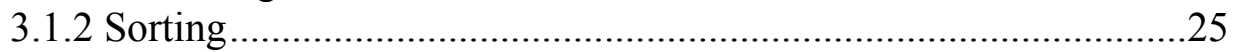

3.2 Overview of Covered Criteria by Analyzed Certification Systems................33

3.3 Organizing in Groups of Importance - Weighting .........................................37

Chapter 4 Analyzing Current Focus of Green Building Certification Systems ..................45

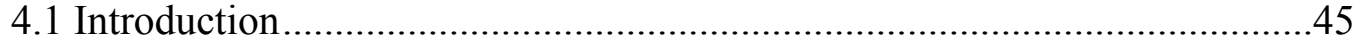

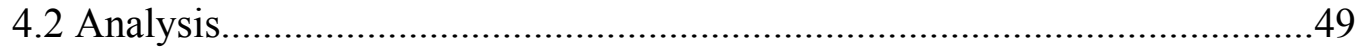

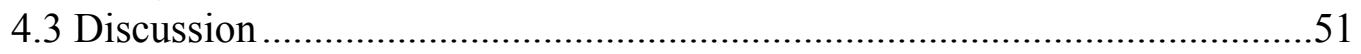

Chapter 5 Analyzing the Environmental Performance of Green Building Certification

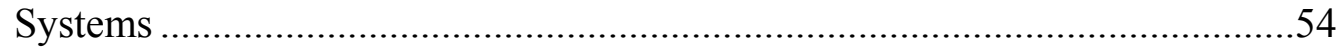

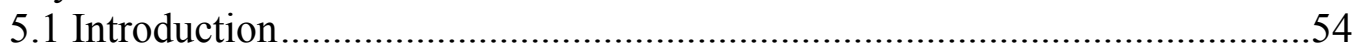

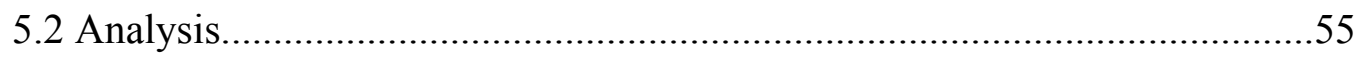

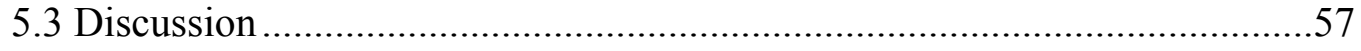

Chapter 6 Evaluating the Sustainable Performance of Green Building Certification

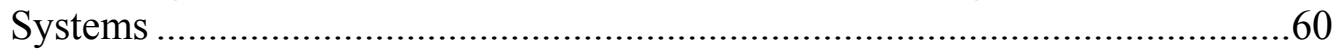

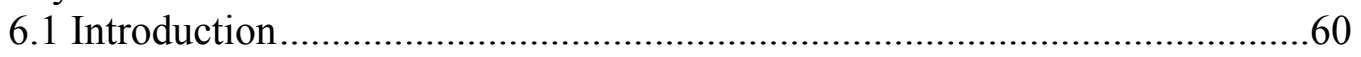

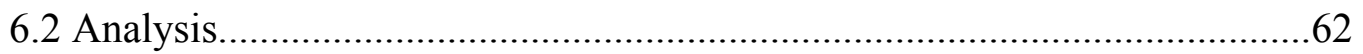

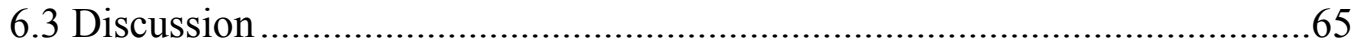

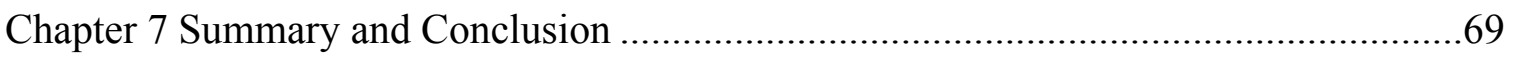

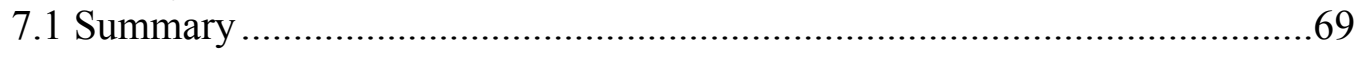

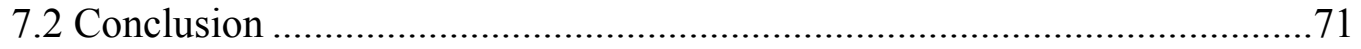




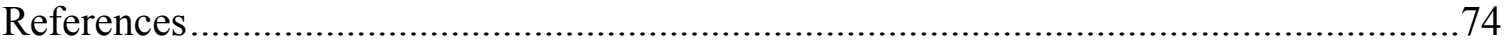

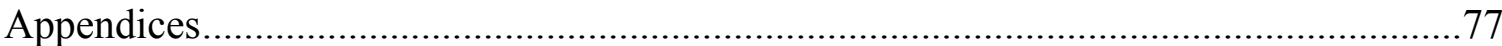




\section{LIST OF TABLES}

TABLE

PAGE

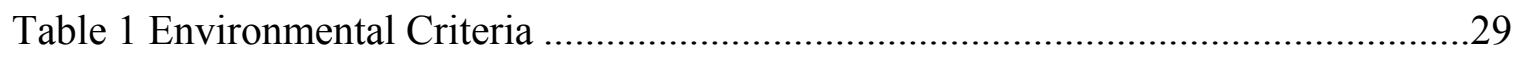

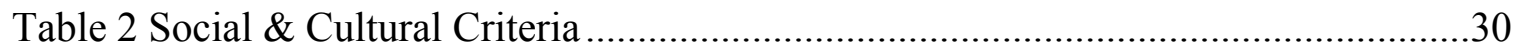

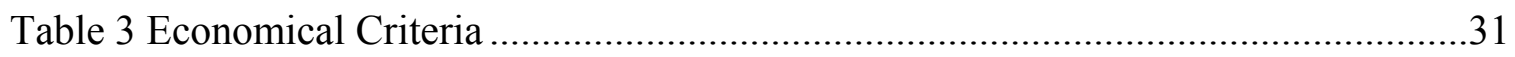

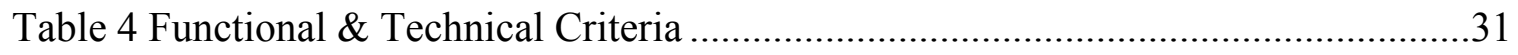

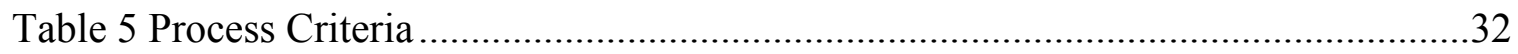

Table 6 Most Covered Issues Within Current Certification Systems ...............................38

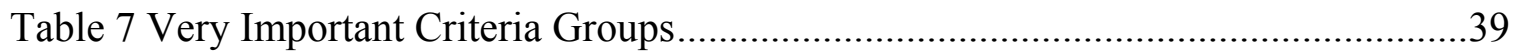

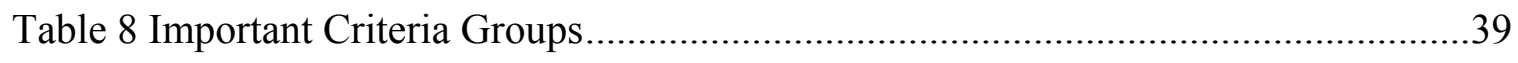

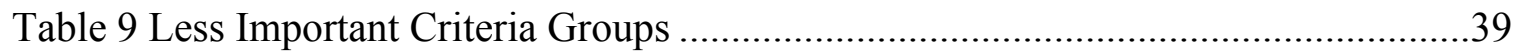

Table 10 Combination of Current Used Scoring Approaches for Establishing the Point

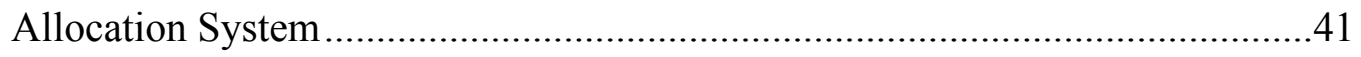

Table 11 Calculations Steps for Establishing the Point Allocation System ....................43

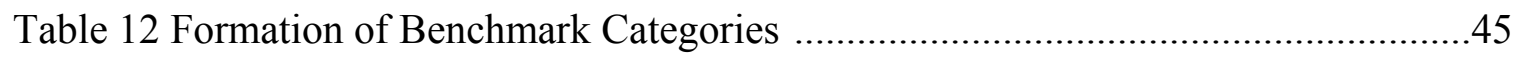

Table 13 Example of Calculating Percentage Contribution with LEED .........................47

Table 14 Example of Calculating Percentage Contribution with BREEAM...................47

Table 15 Example of Calculating Percentage Contribution with DGNB ........................48

Table 16 Sample Table for the Analysis by Current Used Categories with LEED ...........50

Table 17 Sample Table for the Analysis by Current Used Categories with BREEAM ....50

Table 18 Sample Table for the Analysis by Current Used Categories with DGNB .........50

Table 19 Summary Table for Analysis of LEED, BREEAM, and DGNB by Current

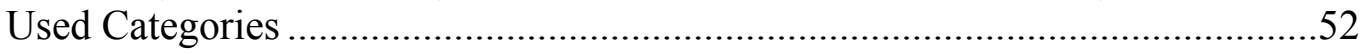


Table 20 Sample Table for the Analysis by Environmental Criteria with LEED

Table 21 Sample Table for the Analysis by Environmental Criteria with BREEAM .......56

Table 22 Sample Table for the Analysis by Environmental Criteria with DGNB ............56

Table 23 Summary Table for Analysis of LEED, BREEAM, and DGNB by Environmental Criteria.........................................................................58

Table 24 Sample Table for the Analysis by Weighted Criteria with LEED.....................63

Table 25 Sample Table for the Analysis by Weighted Criteria with BREEAM ..............63

Table 26 Sample Table for the Analysis by Weighted Criteria with LEED ....................64

Table 27 Summary Table for Analysis of LEED, BREEAM, and DGNB by Weighted Criteria .66 


\section{LIST OF FIGURES}

FIGURE

PAGE

Figure 1 Green Building and the Sustainability of Real Estate are Important Themes for the Building....

Figure 2 Influence of Aspects of Sustainability on Decisions about Acquiring Real Estate. 3

Figure 3 Relationships of the International Certification Systems to Each Other .5

Figure 4 How the International Certification Systems are Derived from Each Other.........6

Figure 5 Outline of Objectives.............................................................................. 10

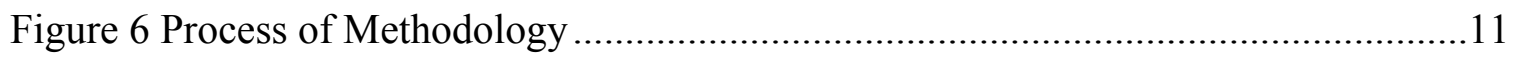

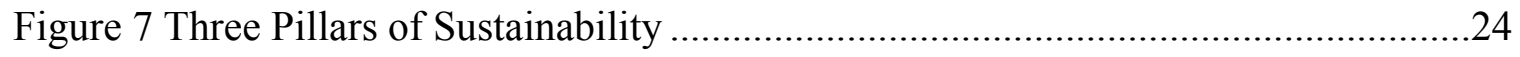

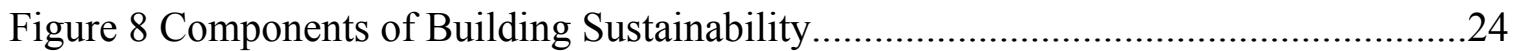

Figure 9 Certification Main Criteria Group Environment and its Subgroups ..................26

Figure 10 Certification Main Criteria Group Social \& Cultural and its Subgroups .........27

Figure 11 Certification Main Criteria Group Economic and its Subgroup......................27

Figure 12 Certification Main Criteria Group Functional \& Technical and its Subgroups 28

Figure 13 Certification Main Criteria Group Process and its Subgroup..........................28

Figure 14 Overview of Analyzed Green Building Certification Systems .......................33

Figure 15 Covered Environmental Criteria by Selected Green Building Certification

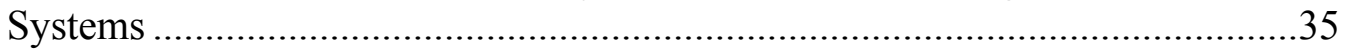

Figure 16 Covered Social \& Cultural Criteria by Selected Green Building Certification

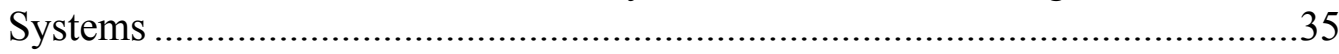

Figure 17 Covered Economical Criteria by Selected Green Building Certification Systems 36

Figure 18 Covered Functional \& Technical Criteria by Selected Green Building Certification Systems 
Figure 19 Covered Process Criteria by Selected Green Building Certification Systems ..36

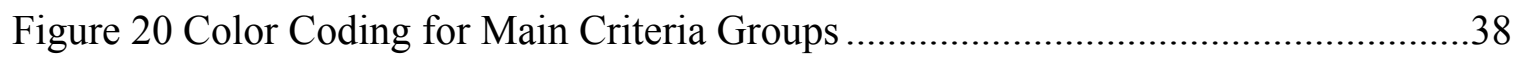

Figure 21 Comparison of LEED, BREEAM, and DGNB by Current Used Categories....52

Figure 22 Comparison of LEED, BREEAM, and DGNB by Current Used Categories....53

Figure 23 Comparison of LEED, BREEAM, and DGNB by Environmental Criteria ......59

Figure 24 Comparison of LEED, BREEAM, and DGNB by Groups of Importance........67

Figure 25 Comparison of LEED, BREEAM, and DGNB by Main Groups .....................68 
Chapter 1 Introduction

\subsection{Background}

Today it is becoming clear that sustainability also has a considerable impact on the building industry. Hence, building owners, as well as users, are increasingly conscious that aspects of sustainability should be considered in the erection of new buildings, the renovation of existing buildings, and in the operation of buildings. On the other hand, numerous new approaches to the erection and marketing of buildings reflect the call for an ever-increasing flexibility, with shorter payback periods and the separation of the roles of investor and user.

With the use of sustainable technologies in the building sector, and more environmentally friendly products, we can reduce not only $\mathrm{CO}_{2}$ emissions, but also a building's running cost over its entire life cycle. Today the consideration of a property's entire life cycle already plays an increasingly important role in planning. In addition to running costs, the emphasis here is on aspects such as adaptability for use by third parties, high suitability for conversion (possibility to refit the building for different kinds of use, or modularity of the building), flexible design of the spatial structure, such as the adaptability of the electrical, media, heating and water supply, and disposal systems.

Surveys conducted amongst project developers, investors, designers and users show that sustainability becomes an important criterion for decision-making with regard to the design and marketing of buildings. Ernst \& Young Real Estate GmbH (2008) examined the importance of green building for stakeholders of the construction and real estate industry for their business purposes and the influence of sustainability aspects for the 
purchase of a property (Figure 1 and 2). Figure 1 underlines the significance of sustainability for the majority of investors $(82 \%)$ and retail companies $(73 \%)$. Figure 2 indicates that three-quarters of the surveyed stakeholders already consider sustainability aspects in their decision-making process about acquiring real estate; all of the surveyed companies confirmed this influence for future business plans.

Is "green building" or the sustainability of real estate an important theme for your business?
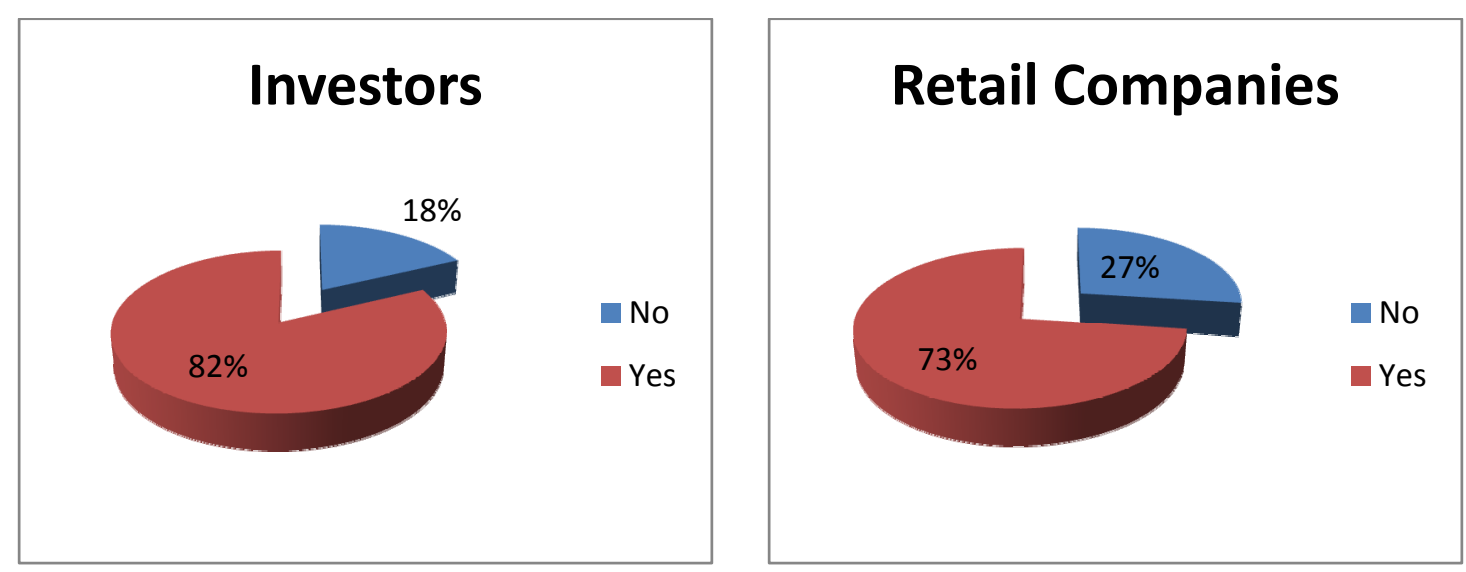

Figure 1 Green Building and the Sustainability of Real Estate are Important Themes for the Building Sector (Ernst \& Young Real Estate GmbH 2008).

Although a sustainable property does not always necessarily mean a higher selling price or rental income, a building that take into account environmental, economic, and social aspects and which can certify this with a sustainability certificate, such as Leadership in Energy and Environmental Design (LEED, USA), are easier to market. However, surveys have also indicated that in the future the market will be willing to pay higher prices for sustainable buildings with lower $\mathrm{CO}_{2}$ emissions proven by certificates. 
To what extent is the decision to buy a particular property influenced by aspects of sustainability?

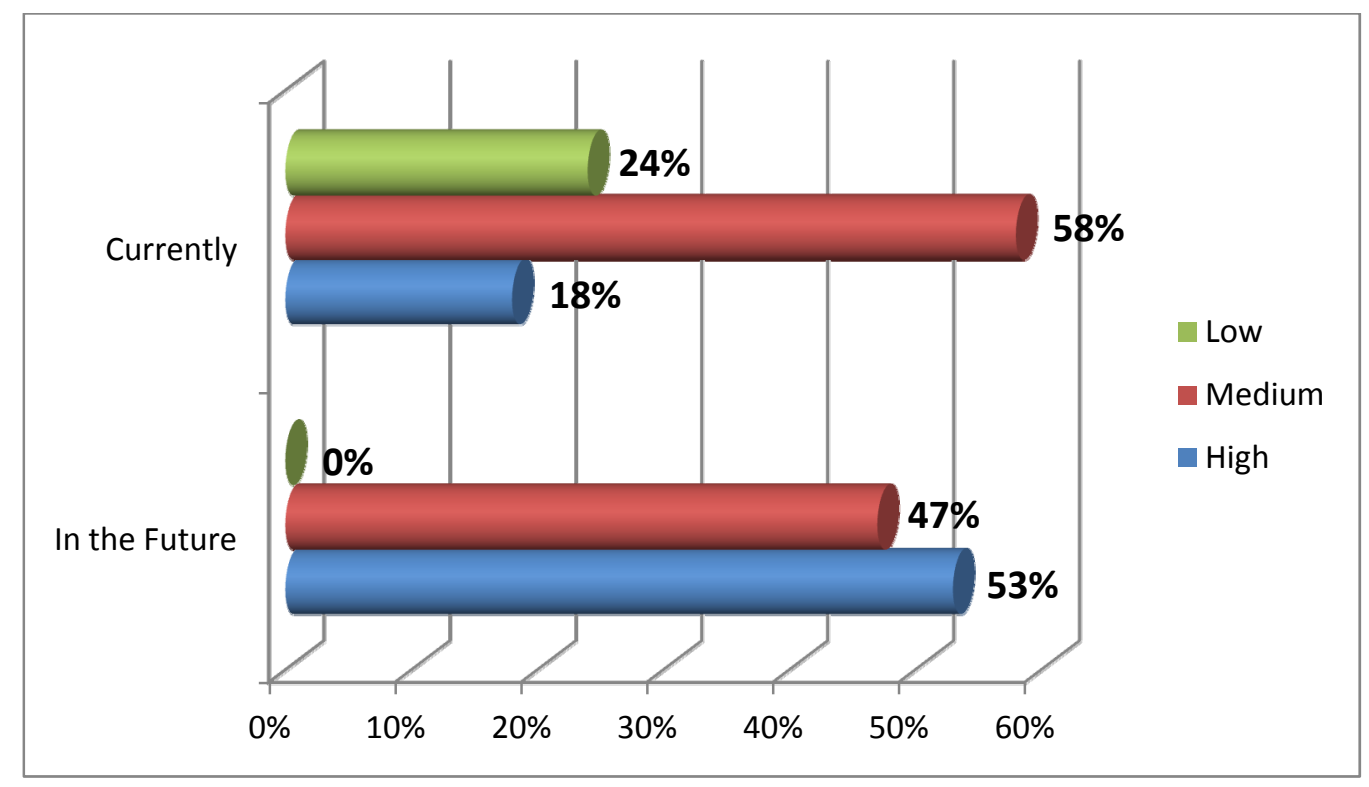

Figure 2 Influence of Aspects of Sustainability on Decisions about Acquiring Real Estate (Ernst \& Young Real Estate GmbH 2008).

The building industry in particular has a considerable impact on the sustainable actions of our society since immense amounts of energy are consumed. Furthermore, construction materials and buildings are extremely durable, and therefore, they have an influence on our environment and society for long periods of time. Building construction causes around $60 \%$ of all waste produced, and around $40 \%$ of worldwide greenhouse gas emissions result from the production and use of buildings (European Union 2002).

Since the end of the 1980s, Germany and Austria have introduced energy saving regulations and promoted the construction of low energy buildings and passive houses to implement environmental and energy-related aspects in the building sector, i.e. a scientifically oriented ecological approach. In other countries, such as France, Great 
Britain and the USA, environmental goals in the building industry were, in contrast, defined with the aid of catalogues of criteria, i.e. in quantitative terms, which after a practical testing phase were further updated and adapted to match current technological levels. In describing "environmental sins" (Ebert, Eßig, and Hauser 2011), reference is made to concentration levels of pollutants or other contaminants, of which there are specified levels that may not be exceeded. For this reason, green building certification systems defining the quality of buildings, especially in terms of their energy efficiency, have become obligatory. However, up until now there has been a lack of widely acceptable, tried and tested evaluation tools that provides a comprehensive assessment of a building's sustainability (Ebert, Eßig, and Hauser 2011). Different certification systems, such as the Leadership in Energy and Environmental Design LEED), the Building Research Establishment Environmental Assessment Method (BREEAM, Great Britain), the German Sustainable Building Council (DGNB, Germany), or the Comprehensive Assessment System for Built Environment Efficiency (CASBEE, Japan) etc. have been developed, for the most part, by building up on each other (see Figures 3 and 4) and compared to each other. Yet, nobody has established a guideline or a path for creating a universal certification approach (Cole 2002).

The aim of building certification systems is to provide transparency and clarity on environmental aspects of sustainability. However, new systems are constantly being introduced, such as VERDE (Spain) or Protocollo Itaca (Italy) with their own systems and methods of assessing sustainable building quality. Consequently, there is an urgent need for an up-to-date guide to the field of established sustainability labels with a comprehensive set of criteria. Standardization of the criteria at an international level is 
not yet within sight due to the prevailing regional differences. If this standardization was to be achieved, the result would not only be significant synergies and cost savings, but also a maximum degree of transparency and comparability of sustainability in buildings.

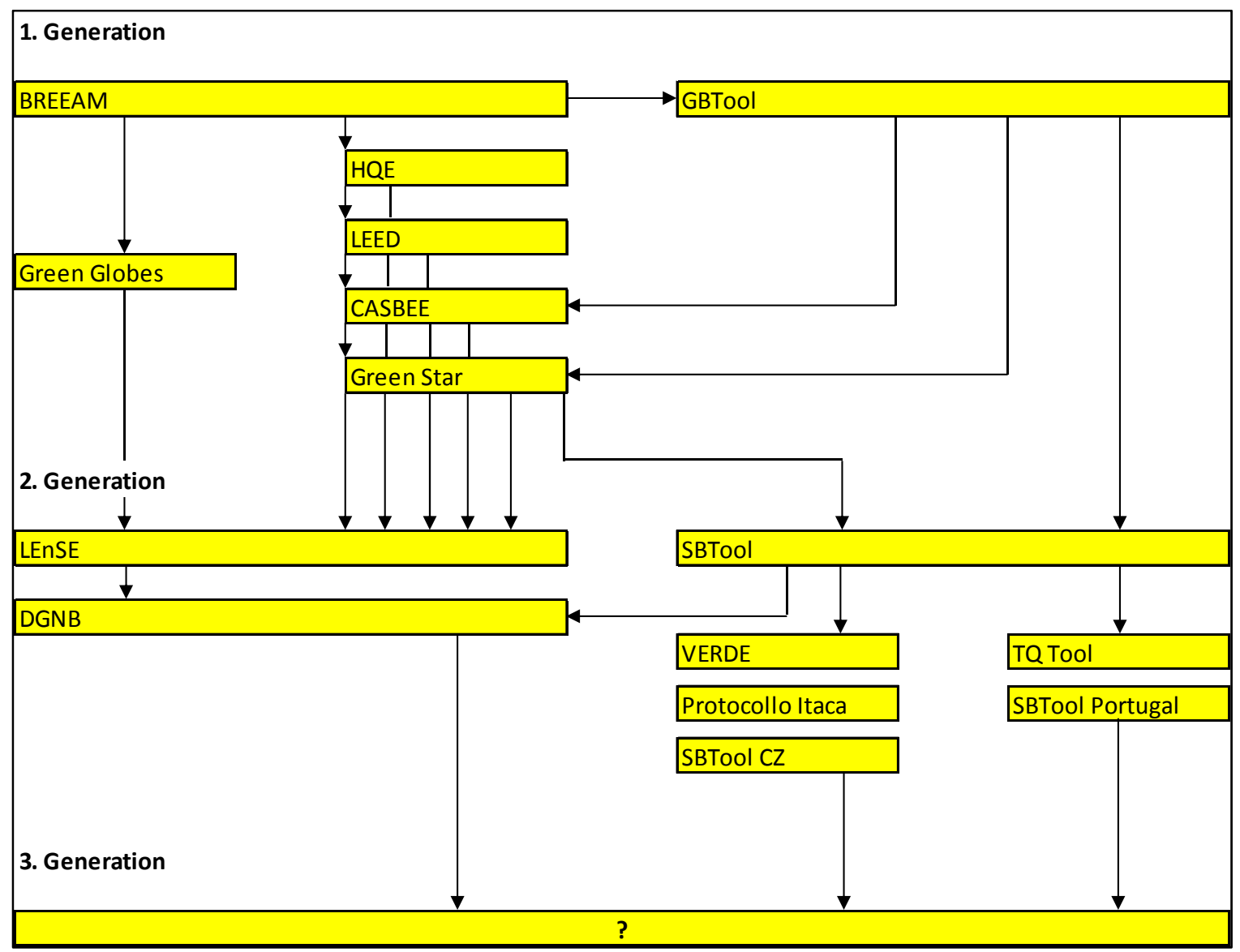

Figure 3 Relationships of the International Certification Systems to Each Other (Eißig 2010) 


\begin{tabular}{|c|c|c|}
\hline Assessment tool & Country & Based on \\
\hline $\begin{array}{l}\text { BREEAM (Building Research Establishment } \\
\text { Environment Assessment Method) }\end{array}$ & Great Britain & - (first assessment system) \\
\hline HQE (Haute Qualité Environnementale) & France & BREEAM \\
\hline $\begin{array}{l}\text { LEED (Leadership in Energy and Environmental } \\
\text { Design) }\end{array}$ & USA & BREEAM \\
\hline Green Globe & Canada & BREEAM \\
\hline $\begin{array}{l}\text { CASBEE (Comprehensive Assessment System } \\
\text { for Building Environment Efficiency) }\end{array}$ & Japan & BREEAM, LEED \\
\hline Green Star (Green Building Council of Australia) & Australia & LEED, BREEAM \\
\hline GBAS (Green Building Assessment System) & China & LEED, BREEAM, CASBEE \\
\hline $\begin{array}{l}\text { DGNB (Deutsches Gütesiegel Nachhaltiges } \\
\text { Bauen) }\end{array}$ & Germany & $\begin{array}{l}\text { LEED, BREEAM, CASBEE, } \\
\text { HQE, Green Star }\end{array}$ \\
\hline Protocollo Italia & Italy & SBTool \\
\hline TQ (Total Quality) & Austria & SBTool \\
\hline SBTool Portugal & Portugal & SBTool \\
\hline SBTool CZ & Czech Republic & SBTool \\
\hline VERDE & Spain & SBTool \\
\hline
\end{tabular}

Figure 4 How the International Certification Systems are Derived from Each Other (Eißig 2010) 


\subsection{Problem Statement}

Certification systems currently focus environmental aspects. At the same time, they must be designed to compare social an economic issues of buildings worldwide. The ability to meet these requirements is one of the main challenges the future faces.

Most of the seals of quality so far have been developed to emphasize on the needs of "Green" criteria, and therefore neglect other aspects of sustainability. The assessment models used as a basis differ greatly and illustrate sustainability in the building sector in very different ways. For example, LEED uses, depending on the project type, seven or eight categories for its assessment, such as "Sustainable Sites", "Water Efficiency" etc. (USGBC 2012), whereas BREEAM includes ten categories, by adding the category "Management" and others (BREEAM 2012). To date, systems have only assessed partial aspects of sustainability, such as energy efficiency, ecology or quality of location, or assessments have been restricted to only part of a building's life cycle, e.g. to the planning of its individual phases or to the assessment of completed buildings.

Although numerous initiatives to develop a uniform international method for assessing the sustainability of buildings have already been launched, no uniform seal of quality has yet been established, e.g., by the organization International Initiative for a Sustainable Built Environment (iiSBE) at the end of the 1990s (Cole 1999) or by the Sustainable Building Alliance (SB Alliance). Nowadays, even at national level, different assessment methods exist alongside each other (e.g., in the USA or Germany).

Several studies have already been undertaken at international and European levels, for example, the United Nations Environmental Program - Sustainable Buildings and Climate Initiative, to improve the content of the various assessment systems and to 
facilitate comparison. However, none of them was able to identify and investigate sufficiently the indicators which could be used in any region and every country, while at the same time allowing comparison of the results.

Therefore, this research study will try to support the green building community to find a comprehensive set of indicators for the measurement of a building's sustainability, and for the comparison of existing rating methods. 


\subsection{Objectives}

This research's primary objective is the evaluation of the sustainability performance of current green building certification systems. Any certification system has to cover certain areas of sustainability. This research attempts to evaluate how far beyond "Green" are the current building certification systems.

To be able to implement this analysis, the study has to establish benchmarks to measure the extent of sustainability assessment in selected certification systems. Hence, the main challenge is the identification of a comprehensive set of sustainable indicators.

In addition, contemporary green building certification systems do not sufficiently consider the building's overall life cycle while examination, but are more focused on the operational phase. However, it is essential to evaluate all impacts for each criterion occurring from the material extraction to the product reuse or disposal, known as cradleto-grave analysis. Therefore, future updates of current and new certification systems must consider all of the building's life cycle phases, to facilitate a sound investigation of the buildings' sustainability.

Further areas of improvements will be identified in the course of the analysis. The figure in the following page gives an outline about how the miscellaneous objectives are related to each other. 


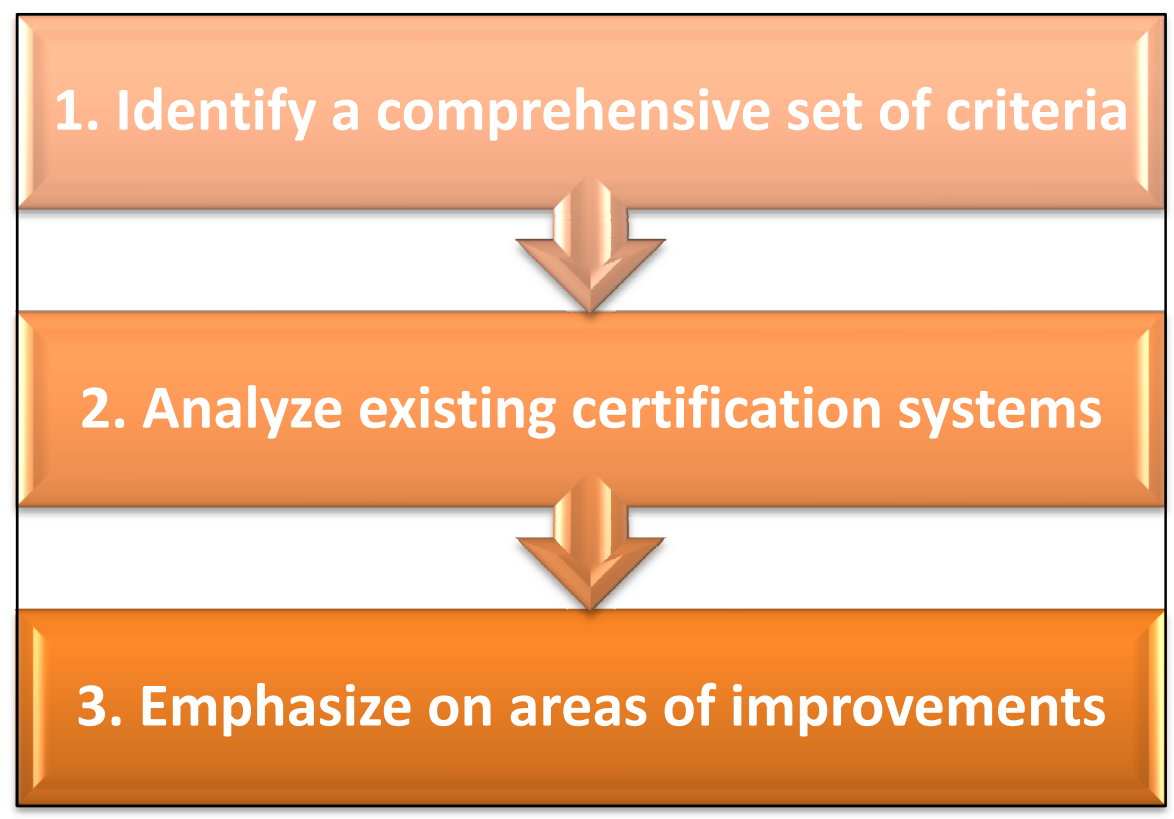

Figure 5 Outline of Objectives 


\subsection{Methodology}

In order to achieve the aforementioned objectives, this research will involve the following phases:

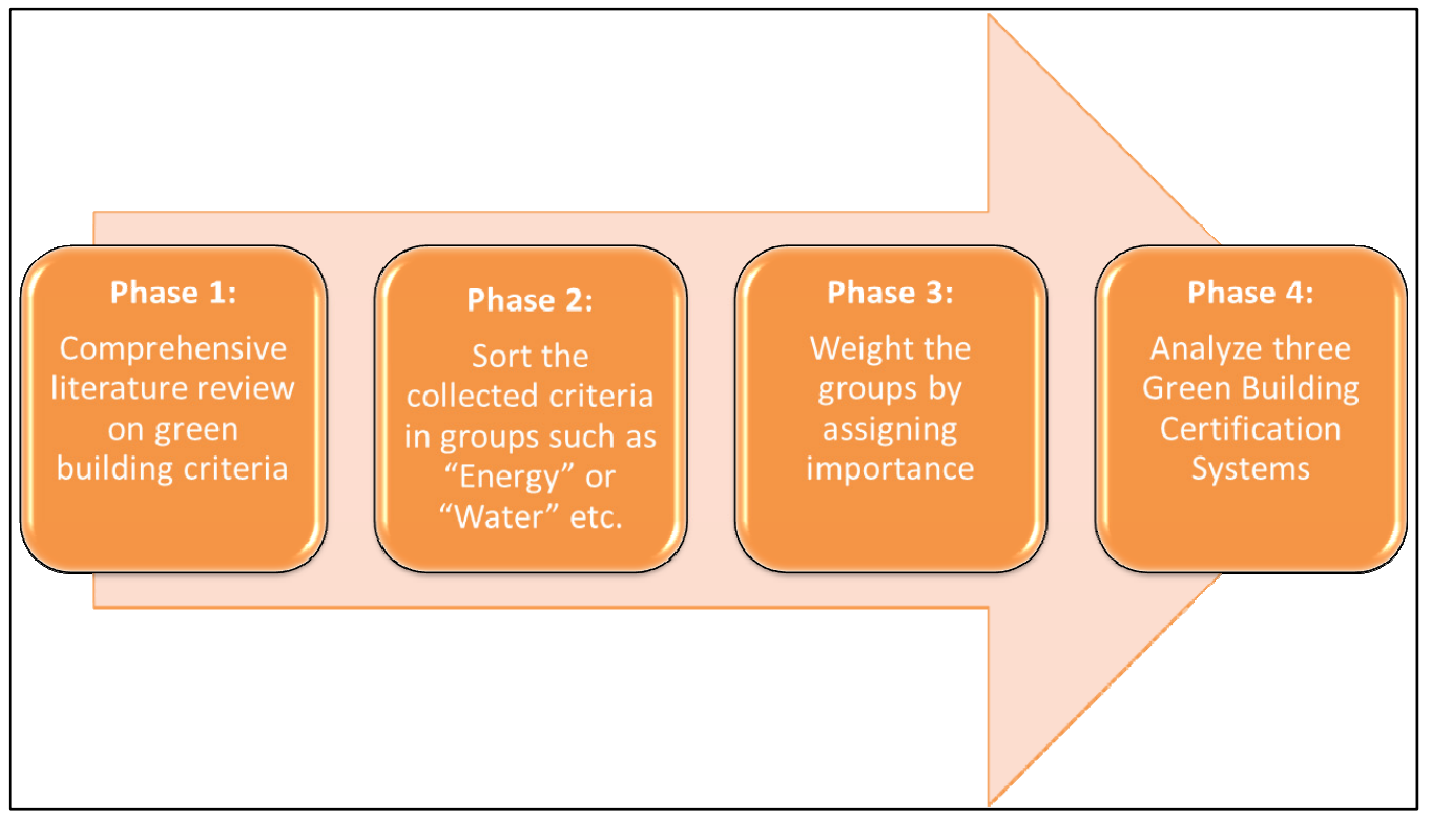

Figure 6 Process of Methodology

\section{Phase 1:}

A comprehensive literature review on green and sustainability building criteria will be conducted. That includes criteria already available in current certification systems and criteria that are proposed for present or new certification systems by different participants of the green building trade, either from the industry or from academia. 


\section{Phase 2:}

Afterwards, the collected criteria will be sorted under the main components of sustainability. The sorting will be primary based on the three pillars Economic, Environmental, and Social. The research will try to detect further elements which may influence building sustainability.

Phase 3:

Subsequently, the collected criteria will be weighted with regard to their importance. Therefore, the weighting process will be organized in categories of importance. That means groups will be established that indicate how important the respective criterion is since different criteria have dissimilar significance. Each group will have a numerical indication for its importance which will be applied for the sustainability evaluation of green building certification systems (see Phase 4).

\section{Phase 4:}

This section will include three types of analyses. The reason for this number is outlined as follows:

The first serves the purpose of identifying which categories are currently considered in the respective green building certification system. It will highlight how much emphasis is placed on the categories by each of the three certification systems. The categories applied for the evaluation are a combination of the sections presently used by the three 
certification systems. With that result, it can be demonstrated how challenging it is to compare green building systems with each other.

The second analysis constitutes the topic "Green." It solely describes the environmental friendliness, in this case of a building. The U.S. Green Building Council (2011) presents its LEED system as a "Green Building Program," whereby Building Research Establishment (2011) claims that its certification system BREEAM is an "Environmental Assessment Method." German Sustainable Building Council (2012) describes its DGNB as an "Assessment of the Sustainability of Buildings..." which leads to the last analysis, and will be discussed afterwards. With merely the collected but not weighted environmental ("green") criteria, each system will be evaluated to what extend it assesses a building with regard to environmental aspects of sustainability. It is an additional assessment besides the first analysis which merely focuses on the difference between the coverage of categories by each certification system.

The last analysis, as already indicated, includes all components of building sustainability. It deals with the main purpose of the study, the Sustainability Evaluation of Green Building Certification Systems. That implies that not only environmental issues will be considered but also economic, social, and additional aspects that will be presented later. Consequently, the complete set of collected criteria will be applied for this evaluation. In addition, the subject of weighting will be included. That means that each criterion will obtain a number value with regard to its importance. 


\subsection{Thesis Organization}

In order to organize the thesis in different chapters, phase 1 is included in chapter 2 and phase 2 and 3 are incorporated in chapter 3 Identifying Green Building Criteria; this chapter contains two sections. The first section deals with the collection of the green building criteria and the sorting of the criteria in categories, such as Energy or Water. In the second section, those main groups are organized in categories of importance.

The entire analysis of green building certification systems contains three separated evaluation levels. The first level, presented in chapter 4, utilizes the groups and criteria that the current green building certification systems consider in their present assessment. The analysis in chapter 5 applies only the environmental criteria that were collected but not weighted. In chapter 6 , the third evaluation is based on all collected and weighted criteria.

The last chapter, chapter 7, incorporates a summary and conclusion of the research and recommendations for future research and the further development of certification systems. 


\section{Chapter 2 Literature Review}

\subsection{Introduction}

Indicators, also known as criteria, perform various functions. They can support the decision-making process and increase the efficiency of actions by simplifying, clarifying and making aggregated information available. One of those functions is to measure the progress toward sustainable development.

Green building rating systems measure a building's sustainability by applying a set of criteria organized in different categories, such as "Energy" or "Water Efficiency". For each criterion a certain number of points is allocated. The total score defines the type of certification a building receives, e.g. in LEED "Certified", "Silver", "Gold" or "Platinum". Unfortunately, different certification systems judge building sustainability with different sets of certification criteria. Therefore, it is impossible to compare current green building certification systems by merely using their own criteria. In addition, obviously as marketing strategy, any provider poses its certification systems as sound and prudent, and emphasizes the drawbacks of the competitors.

Many related research studies about establishing the proper set of green building criteria have been undertaken in the last decade, with an outlook for additional necessary investigation. The literature review gives a summarized overview of the state-of-art and knowledge about which criteria a green building certification system has to consider in order to properly measure a building's sustainability. Different political and voluntary organizations, alliances of industry and academia, and individual and groups of scientists have conducted researches in this field. 


\subsection{Political and Voluntary Organizations}

The United Nations Department of Economic and Social Affairs' publication Indicator of Sustainable Development: Guideline and Methodologies (2007) gives a set of indicators on sustainable development, since indicators could play an important role in supporting countries that make informed decisions concerning sustainable development. The set contains 96 indicators, organized in a thematic/sub-thematic framework. The report emphasizes that not all indicators are relevant for any country, nor is data easily available or could be made available within reasonable time and costs.

The International Organization for Standardization (ISO) released the technical specification ISO/TS 21929-1 Sustainability in building construction - Sustainability indicators - Part 1: Framework for the development of indicators for buildings (2011) and established a core set of sustainability indicators. ISO's goal is to consider these indicators for the purpose of rating the sustainability performance of both new and existing buildings over the entire life cycle. ISO/TS 21929-1 defines a framework for sustainability indicators, which consider not only the environmental impact and economic, social and cultural improvement, but also the technical performance.

The European research project Label for Environmental, Social and Economic Buildings (LEnSE, 2008) developed a list of issues, which needs to be included in the certification process. The first step was to review and analyze existing certification systems. Thereupon, the group established a long list of criteria and grouped them in the sustainability categories Environmental, Social, and Economic. The final step included the development of 36 criteria, whereby the focus was on issues not developed in already existing certification systems. 
A further European project called OPEN HOUSE (2011) tried to establish a transparent and common building assessment method, particularly for the European market. In the research's first phase, any indicators of all existing green building certification systems were gathered. The next phase implied the grouping of the collected indicators. Those groups were divided in the familiar 3 pillars of sustainability and two additional groups, called technical characteristics and process quality.

Sustainability Performance Assessment and Benchmarking of Buildings (2011), initiated by the European Commission, defined several work packages. Two of those analyzed the sustainability issues and recommended a list of indicators. By doing that, the research group pointed out that functional, technical and process categories have to be considered. Functional and technical quality is explained by the fact that any building has to be first and foremost fit for purpose. If it is not, it is fundamentally unsustainable. Process qualities have a significant influence. Additionally, the consortium referred to ISO 21931-1 that recognizes the importance of accounting for processes related to the building and its construction. 


\subsection{Industry and Academic Alliances}

The Sustainable Building Alliance (2009), calling itself an international non-profit organization, tries to promote shared indicators for rating buildings with the objective to accelerate the adoption of sustainable building practices. One of the main goals for its research program is to find a core set of indicators, and thus to facilitate inter-building and inter-country comparisons, and to support the development of future green building certification systems. By doing that, the organization selected a large number of indicators of existing approaches and standards under development.

The International Initiative for a Sustainable Built Environment (2012), another international non-profit organization, also aims to actively facilitate and promote the adoption of policies, methods, and tools to accelerate the movement towards a global sustainable built environment. The organization devised its SBTool assessment framework and claims that it allows an international comparison of buildings from different countries. The tool integrates a group of indicators, called Service Quality. This category considers indicators unused so far in current certification systems.

Various members from the industry and the academic field created an alliance named Perfection (2011). Perfection's passion for the indoor environment originates from the fact that it forms the link between the building and its users. Hence, the focus was merely on the definition of performance indicators for the indoor environment as part of the development of a concise assessment scheme for the indoor environment. The alliance partner determined 4 groups that cover the different aspects of a building's indoor environment, such as Positive Stimulation. 


\subsection{Academia}

Feifer (2011) made a very important statement about what to consider as an indicator of today. He stated that sustainability does not only cover measures for green buildings, such as consumption of non-renewable fuels, emissions of greenhouse gas or indoor air quality. In addition, a sustainable building has to address long-term issues, among others, longevity, adaptability and flexibility of the object, or safety and security. Another crucial aspect in his paper is the fact that different stakeholders and at the same time people from various countries have different views and levels of understanding about sustainability. The building industry has to develop a common knowledge and agree to the relative importance for each indicator.

Dirlich (2011) proposed in his paper the inclusion of the following areas in any certification system: environment, economic, socio-cultural, functional, technical, and procedural. The author only provided further specification for the ecological area, namely which indicators should be considered. He did not provide more information for the remaining areas.

Nguyen and Altan (2012) created a table of sustainability indicators, in particular for tall buildings. They justified the characteristic of this kind of indicators by the fact that tall buildings have very distinctive technical and architectural features in comparison to other types of buildings. However, when examining the list of indicators, it does not show any unsuitability for low and medium-rise buildings. The table contains categories, such as Project Management or Resource Consumption, which are already known or considered under a similar title. Nevertheless, the table has single criteria that are not included in 
current certification systems, but have an important role when certifying a building's sustainability.

Alwaer and Clements-Crome (2011) support the concept, as Dirlich (2011) did, to consider technical indicators besides environmental, social, and economic criteria. Measuring a building's technical performance reflects the authors' concept that buildings do not only have to be sustainable but also intelligent. The authors list numerous indicators for all 4 groups.

Liu (2011) criticized the current certification systems' lack of attention on the impacts in the building process throughout the building's life cycle. The scientists behind this research formed the Building Process Assessment Model (BPAM), including a function of sustainability performance at various life cycles of a project. Poston (2010) emphasized the same flaw. In addition, Poston criticized the current focus on energy and environment, and thus a range of sustainability priorities are insufficiently covered. Moreover, the dominating interests of the industry behind the green building certification systems lead to mainstream theories of sustainability.

Nannen (2011) agreed with Dirlich (2011) about the main criteria groups involved in the certification process. The researcher also added technical and process quality to environment, economic and social aspects. He listed various criteria for these two additional groups, such as the quality of project preparation or optimization of use and management. 


\section{Chapter 3 Identifying Green Building Criteria}

The following two sections, 3.1.1 Collecting and 3.1.2 Sorting, deal with phase 1 and phase 2 of the methodology. The subsequent discussion indicates the purpose of these two subjects.

As stated in section 1.2, the evaluation of Green Building Certification Systems is challenging due to the fact that every single system uses its own set of criteria. Therefore, to make the evaluation of certification systems possible, a thorough set of sustainability criteria has to be collected in order to measure the comprehensiveness of a certification system. A comprehensive literature review was conducted to gather green building criteria that should be considered in any Green Building Certification System. The collection procedure included criteria that are already available in current certification systems and criteria that are proposed for present or new certification systems by different participants of the green building trade, either from the industry or from academia. Sources for the gathering process included textbooks, such as "Green Building Certification Systems" (Ebert et al., 2011), web pages and articles of different providers for certification systems, articles from journals and trade organizations, e.g. ASCE, web pages and articles of political and non-profit organizations, among others Sustainability and Performance Assessment and Benchmarking of Buildings (SuPerBuildings), standards from the International Organization for Standardization, research papers, and presentations of conferences, such as the World Sustainable Building Conference 2011.

The first step of the collection procedure involved merely the listing of each criterion under the respective source. However, every source had its own method of grouping the 
different criteria. Feifer (2011) applied, for example, the groups "Environmental dimension," "Economic dimension," and "Social dimension." On the other hand, the organization International Initiative for a Sustainable Built Environment (iiSBE) split the criteria in the "Pre-design phase" and "Design, Construction and Operation Phase." Therefore, a precise arrangement had to be implemented for the purpose of having a clear overview of the numerousness of criteria. As a result, a long list arose that was categorized into five main criteria groups, which are presented and further explained in the following.

Phase 2 of the methodology, termed Sorting, involves a meaningful arrangement of the numerous criteria that were collected but not organized in the course of the literature review. In this case, Sorting has the purpose of grouping and categorizing criteria that target issues with the same or similar subject matter. Since sustainability deals with the areas Environment, Economic, and Social, and the majority of sources from the literature, among others Alwaer (2010), also use this terminology for the individual groups of criteria, this study will establish the same category types.

Section 3.1.1 Collecting and 3.1.2 Sorting present the results of the two processes with several figures and tables. 


\subsection{Collecting and Sorting}

\subsubsection{Collecting}

The reviewed literature provided numerous criteria to consider for green building certification systems. As already discussed in the previous chapter, different areas with regard to sustainability were covered. As one might expect, the main focus lay on the groups Environment, Social and Economic. However, many significant criteria in terms of technical and process quality could be also provided by the literature (see Chapter 2). The close relationship of those additional criteria to sustainability is remarkable. They cover important topics, such as adaptability of a building for changing demands in the future or safety aspects, which have a great influence on a building's sustainability. This addition to the 3 pillars of sustainability gives a more detailed and meaningful statement when it comes to rating a building's sustainability.

Also noticeable is that green building certification systems of the $1^{\text {st }}$ generation, such as LEED or BREAAM, focus on the 3 pillars of sustainability. Although they partially integrate the technical and process related criteria in their rating procedure, they are less considered in comparison with green building certification system of the $2^{\text {nd }}$ generation (e.g. DGNB) that enhances their importance.

Figure 7 and 8 demonstrate the difference between Sustainability and Building Sustainability. The latter involves the 3 pillars and also considers two additional groups, called Functional \& Technical and Process. The next section introduces the criteria in a clearly arranged structure. Therefore, the presentation of those at this point can be dispended with. 


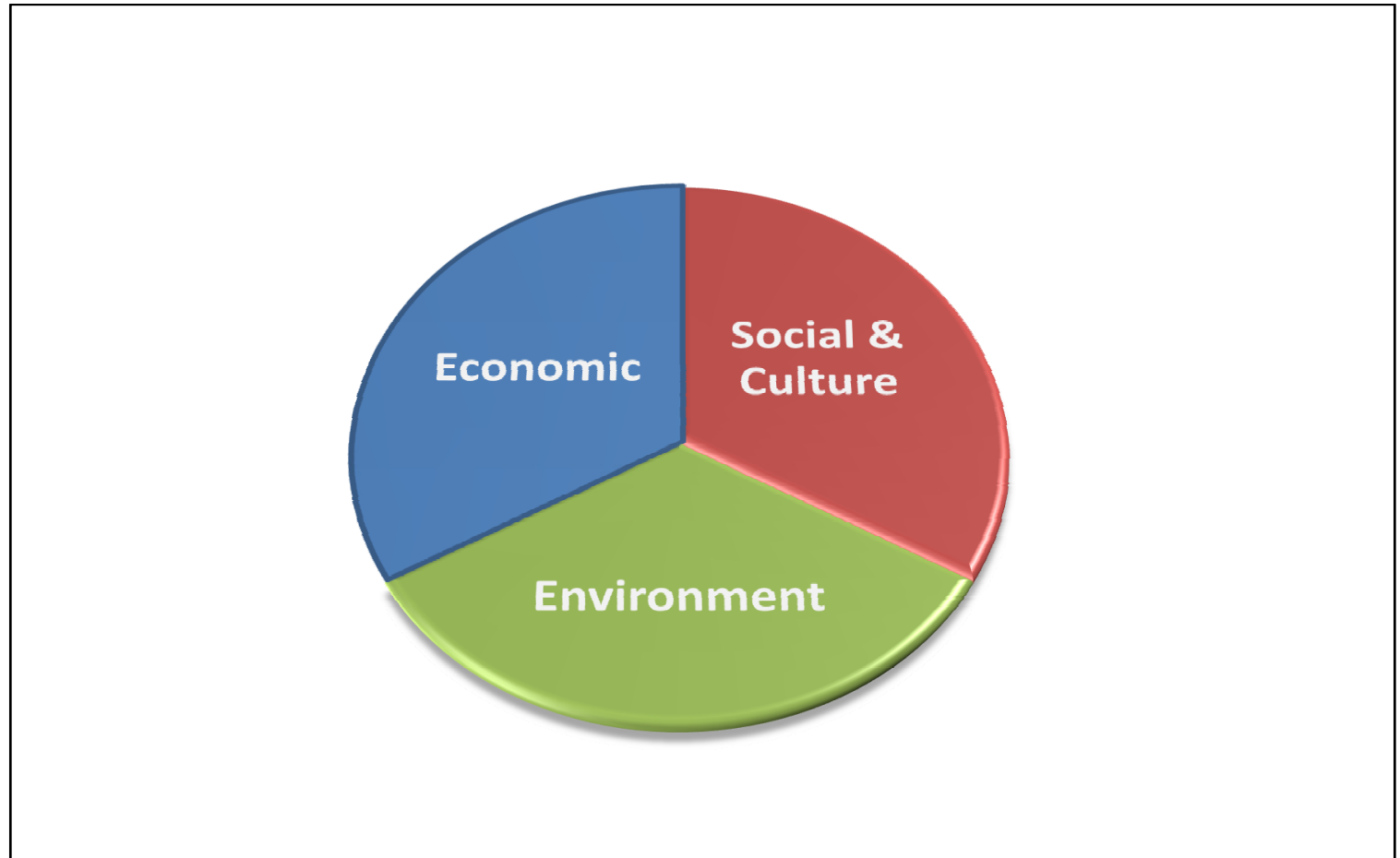

Figure 7 Three Pillars of Sustainability

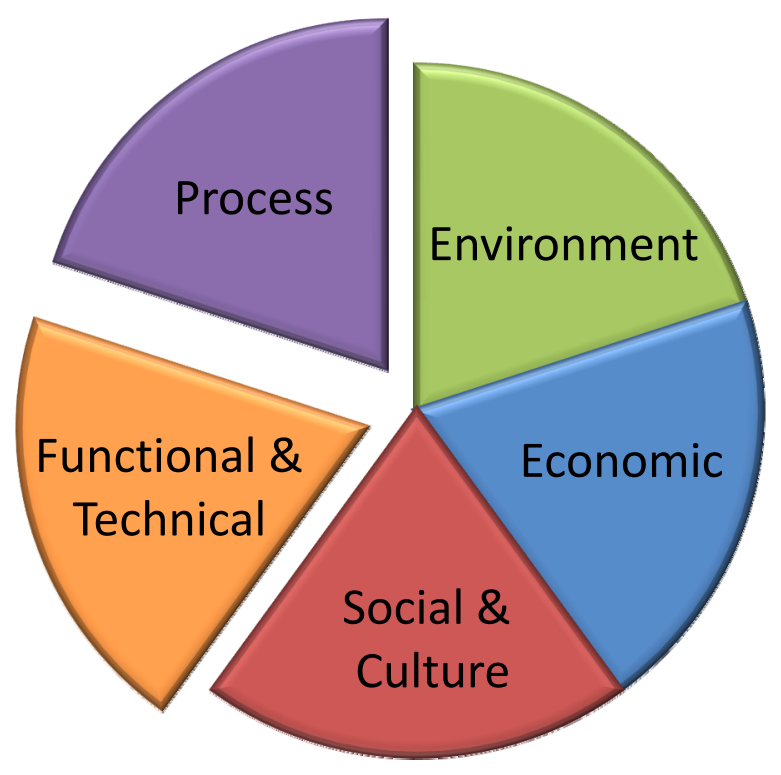

Figure 8 Components of Building Sustainability 


\subsubsection{Sorting}

As already mentioned in the course of the thesis, the criteria can be categorized into the following groups related to and essential for building sustainability: Environment, Social, Economic, Technical, and Process. The group Social also includes cultural issues. Therefore, this group covers two areas, called Social \& Culture, which are related to each other. The same applies to technical and functional aspects, which form the group Functional \& Technical.

Many criteria were related to the same issue, even though their titles were dissimilar. To avoid double counting it was important to merge similar criteria and to determine one common description. The following figures (9-13) present the five groups and their appropriate subgroups. As a result, tables 1-5 indicate all criteria categorized in the respective subgroups.

The first main criteria group considers subjects that influence the environment (Figure 9). It involves eight different subgroups, ranging from Emissions to Resource Depletion. Figure 10 presents the main criteria group Social \& Culture. This group is therefore important since it considers criteria related to, among others, health and satisfaction for building occupants; this group reflects six subgroups. Financial benefits, and this optimally over the entire life of a building, by savings in energy, water, and waste play the crucial role for building owners for their decision process about "building green" or not. As a result, the main criteria group Economy (Figure 11) solely focuses on Life Cycle Costs. The main group Functional \& Technical (Figure 12) involves the four issues safety, security, service quality and usability. The last main criteria group Process (Figure 
13) concentrates on planning and implementation subjects which have a significant effect on building sustainability.

Tables 1-5 present the result of the Collecting and Sorting process. All criteria that were gathered throughout the literature review are arranged in one of the five main criteria groups. The groups Environment (45 criteria) and Social \& Culture (36 criteria) have far more criteria than the remaining categories Economic (6 criteria), Functional \& Technical (22 criteria), and Process (11 criteria).

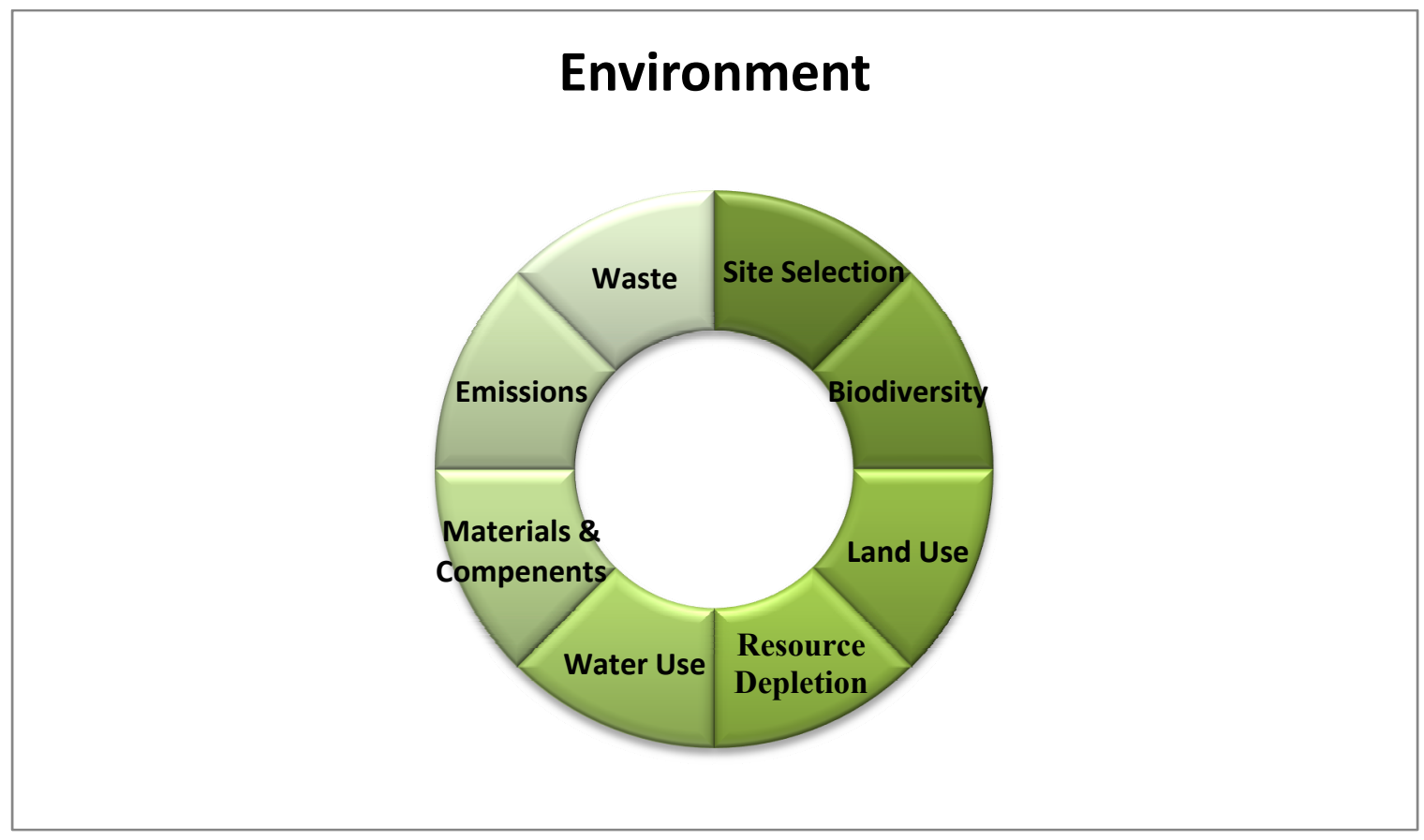

Figure 9 Certification Main Criteria Group Environment and its Subgroups 


\section{Social \& Culture}

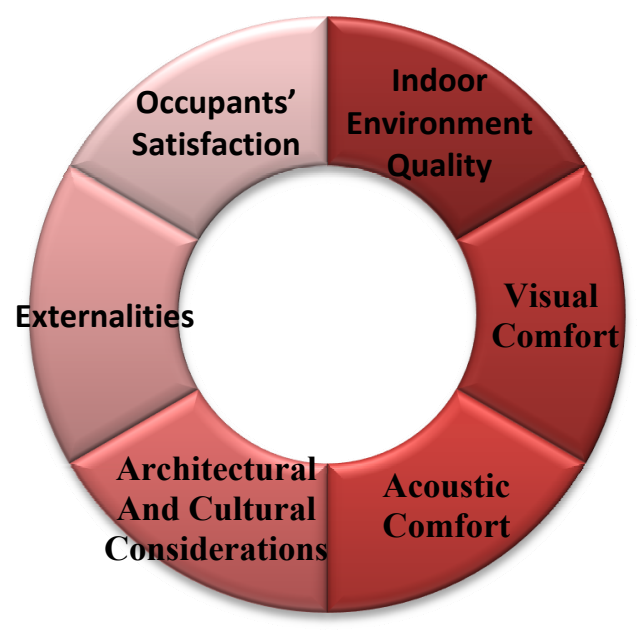

Figure 10 Certification Main Criteria Group Social \& Culture and its Subgroups

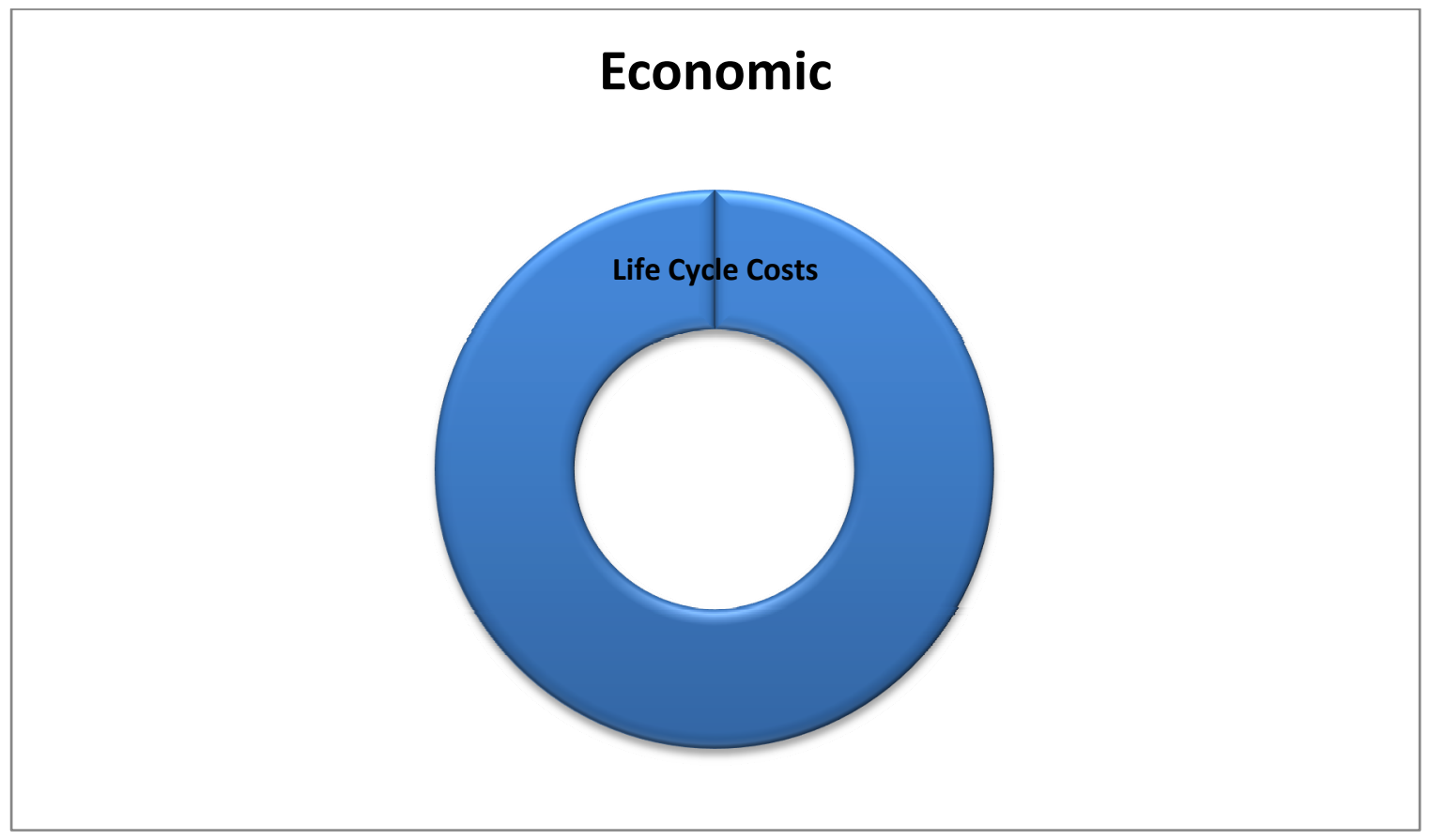

Figure 11 Certification Main Criteria Group Economic and its Subgroup 


\section{Functional \& Technical}

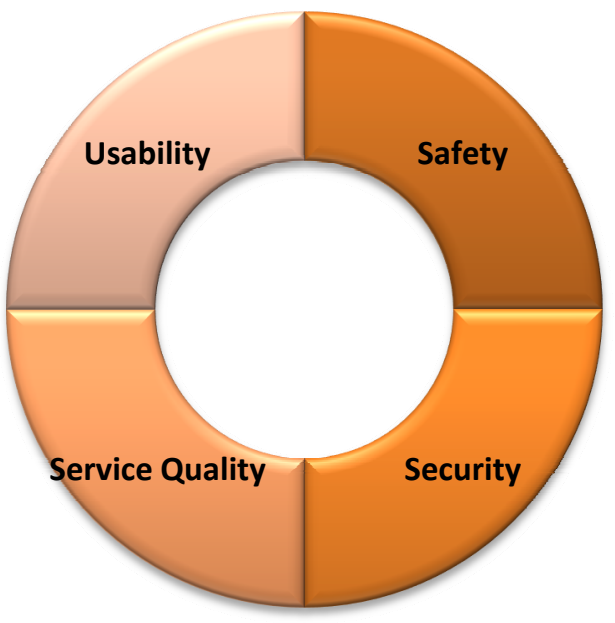

Figure 12 Certification Main Criteria Group Functional \& Technical and its Subgroups

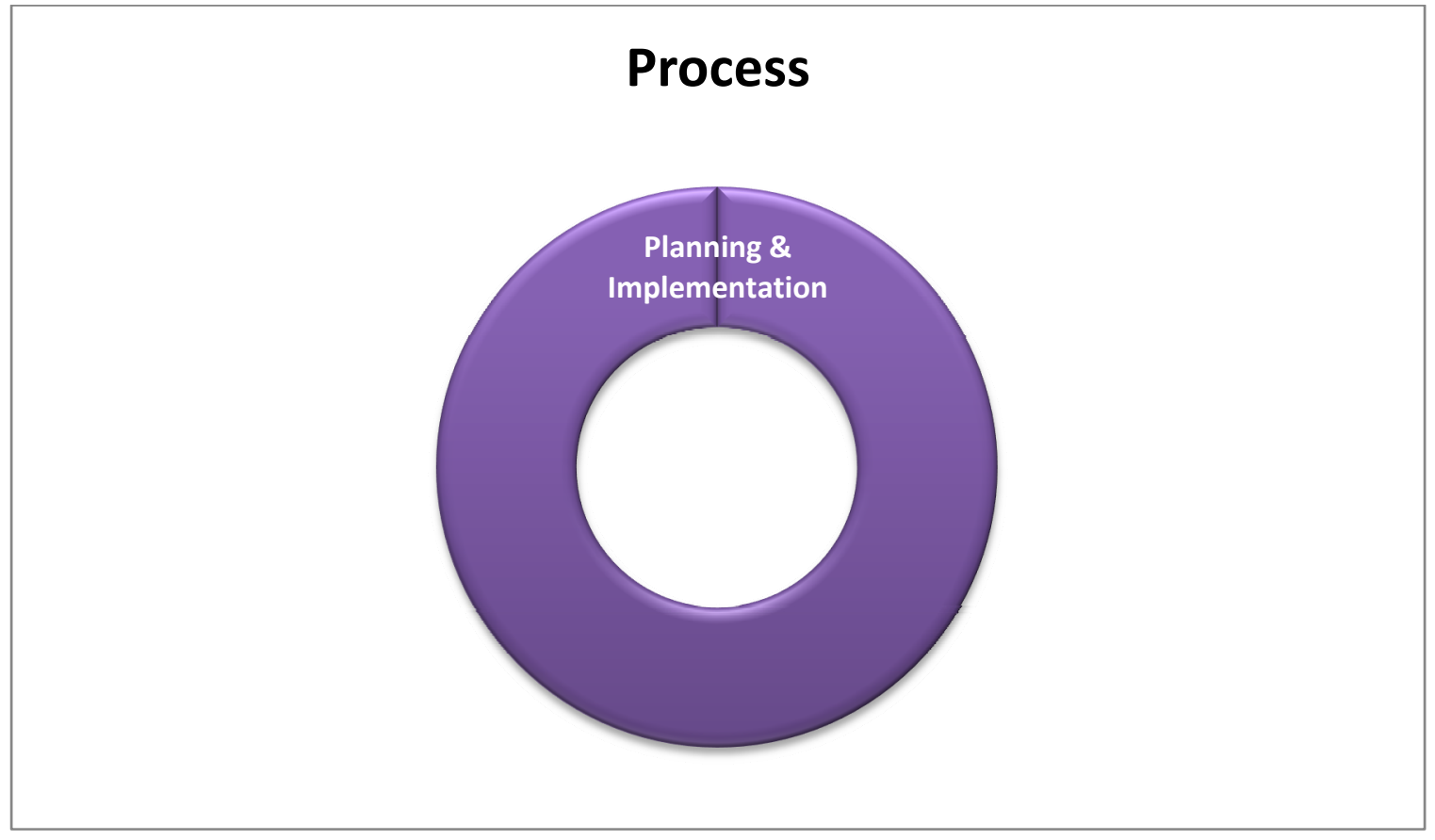

Figure 13 Certification Main Criteria Group Process and its Subgroup 


\begin{tabular}{|c|c|c|}
\hline $\begin{array}{c}\text { Main } \\
\text { Criteria }\end{array}$ & Criteria Group & Criteria \\
\hline \multirow{8}{*}{$\longrightarrow$} & Site Selection & $\begin{array}{l}\text { - Site Location, Site Characteristics } \\
\text { - Infrastructure } \\
\text { - Neighboring Buildings } \\
\text { - Heat Island Effect } \\
\text { - Landscape Inputs } \\
\text { - Risk At The Site }\end{array}$ \\
\hline & Biodiversity & $\begin{array}{l}\text { - Site Ecology } \\
\text { - Eutrophication } \\
\text { - Habitat Management Plan } \\
\text { - Biodiversity }\end{array}$ \\
\hline & Land Use & $\begin{array}{l}\text { - Green Field / Brown Field } \\
\text { - Land Regeneration \& Development }\end{array}$ \\
\hline & Resource Depletion & $\begin{array}{l}\text { - Total Energy Consumption } \\
\text { - Use Of Non-Renewable Primary Energy } \\
\text { - Use Of Renewable Primary Energy } \\
\text { - Use Of Further Energy Resources } \\
\text { - Energy Efficiency of Building Equipment } \\
\text { - Embodied Energy }\end{array}$ \\
\hline & Water Use & $\begin{array}{l}\text { - Potable Water } \\
\text { - Grey Water / Waste Water } \\
\text { - Storm Water } \\
\text { - Runoff } \\
\text { - Planting } \\
\text { - Water Efficiency of Facility \& Appliances } \\
\text { - Embodied Water } \\
\text { - Water Pollution } \\
\end{array}$ \\
\hline & $\begin{array}{l}\text { Materials \& } \\
\text { Components }\end{array}$ & $\begin{array}{l}\text { - Recycled, Reused Materials And Components } \\
\text { - Modular and Standardized Materials And Components } \\
\text { - Certified Materials And Components } \\
\text { - Service Life } \\
\text { - Risks From Materials } \\
\text { - Local / Regional Material }\end{array}$ \\
\hline & Emissions & $\begin{array}{l}\text { - Greenhouse Gas - Carbon Dioxide }\left(\mathrm{CO}_{2}\right) \\
\text { - Greenhouse Gas - Methane }\left(\mathrm{CH}_{4}\right) \\
\text { - Greenhouse Gas - Nitrous Oxide }\left(\mathrm{N}_{2} 0\right) \\
\text { - Greenhouse Gas - Fluorinated Gases } \\
\text { - Acidification } \\
\text { - Ozone Depletion } \\
\text { - Pollution }\end{array}$ \\
\hline & Waste & $\begin{array}{l}\text { - Hazardous Waste } \\
\text { - Non-Hazardous Waste } \\
\text { - Organic Waste } \\
\text { - Inorganic Waste } \\
\text { - Construction Waste } \\
\text { - Radioactive Waste }\end{array}$ \\
\hline
\end{tabular}

Table 1 Environmental Criteria 


\begin{tabular}{|c|c|c|}
\hline $\begin{array}{c}\text { Main } \\
\text { Criteria }\end{array}$ & Criteria Group & Criteria \\
\hline & $\begin{array}{l}\text { Indoor } \\
\text { Environment } \\
\text { Quality }\end{array}$ & $\begin{array}{l}\text { - } \mathrm{CO}_{2} \text {, Formaldehyde and Nitrogen Oxide Concentration } \\
\text { - Indoor Air Pollutants Concentration } \\
\text { - Ventilation Conditions } \\
\text { - Electromagnetic Emissions } \\
\text { - Mold Growth Risk } \\
\text { - Construction Indoor Air Quality } \\
\text { - Indoor Air Quality In Car Parks } \\
\text { - Thermal Comfort } \\
\text { - Air Temperature And Relative Humidity } \\
\text { - Summer / Winter Conditions } \\
\text { - Thermal Zoning }\end{array}$ \\
\hline & Visual Comfort & $\begin{array}{l}\text { - Daylighting } \\
\text { - Illumination } \\
\text { - Lighting Zones And Control: Lighting For Suitable } \\
\text { Tasks In Lux } \\
\text { - Natural Lighting \& Glare }\end{array}$ \\
\hline & Acoustic Comfort & $\begin{array}{l}\text { - Noise From Building And Site } \\
\text { - Background Noise Level } \\
\text { - Reverberation Time }\end{array}$ \\
\hline & $\begin{array}{l}\text { Architectural And } \\
\text { Cultural } \\
\text { Considerations }\end{array}$ & $\begin{array}{l}\text { - Cultural Heritage Integration } \\
\text { - Aesthetic Aspects } \\
\text { - Design And Urban Development } \\
\text { - Monument } \\
\text { - Branding And External Expression } \\
\end{array}$ \\
\hline & Externalities & $\begin{array}{l}\text { - Local Employment Opportunities / Use Of Local } \\
\text { Services } \\
\text { - Community Impact Consultation } \\
\text { - Responsible And Ethical Procurement } \\
\text { - Available Services } \\
\text { - Social Cost Benefit Analysis } \\
\text { - Considerate Constructors } \\
\text { - Neighborhood }\end{array}$ \\
\hline & $\begin{array}{l}\text { Occupants' } \\
\text { Satisfaction }\end{array}$ & $\begin{array}{l}\text { - Access To View } \\
\text { - Privacy } \\
\text { - Feelings And Sensations } \\
\text { - Recreation } \\
\text { - Human Interactions / Relationships } \\
\text { - Interior Qualities }\end{array}$ \\
\hline
\end{tabular}

Table 2 Social \& Cultural Criteria 


\begin{tabular}{|c|c|c|}
\hline $\begin{array}{l}\text { Main } \\
\text { Criteria } \\
\text { Group }\end{array}$ & Criteria Group & Criteria \\
\hline 送 & Life Cycle Costs & $\begin{array}{l}\text { - Initial Costs } \\
\text { - Costs For Operation, Maintenance And Repair } \\
\text { - Replacement Costs } \\
\text { - Risk \& Value Management } \\
\text { - Function Analysis } \\
\text { - Payback Time }\end{array}$ \\
\hline
\end{tabular}

Table 3 Economical Criteria

\begin{tabular}{|c|c|c|}
\hline $\begin{array}{l}\text { Main } \\
\text { Criteria }\end{array}$ & Criteria Group & Criteria \\
\hline \multirow{4}{*}{$\begin{array}{l}2 \\
0 \\
0\end{array}$} & Safety & $\begin{array}{l}\text { - Safety Assessment } \\
\text { - Safety Management }\end{array}$ \\
\hline & Security & $\begin{array}{l}\text { - Site And Building } \\
\text { - Combustion Sources } \\
\text { - Resistance - Storm, High Water } \\
\text { - Resistance - Hail } \\
\text { - Resistance - Earthquake }\end{array}$ \\
\hline & Service & $\begin{array}{l}\text { - Public \& Public Transport Accessibility } \\
\text { - Barrier-Free Accessibility } \\
\text { - Bicycle Comfort } \\
\text { - Pedestrian Comfort } \\
\text { - Car Parking Capacity }\end{array}$ \\
\hline & Usability & $\begin{array}{l}\text { - Demand Of Space } \\
\text { - Area Efficiency } \\
\text { - Capacity } \\
\text { - Occupancy } \\
\text { - Maintainability And Operation Comfort } \\
\text { - Longevity } \\
\text { - Intelligence And Controllability } \\
\text { - Adaptability And Versatility } \\
\text { - Demolition / Reuse / Recycling } \\
\text { - Communications And Mobility }\end{array}$ \\
\hline
\end{tabular}

Table 4 Functional \& Technical Criteria 


\begin{tabular}{|c|c|c|}
\hline $\begin{array}{c}\text { Main } \\
\text { Criteria }\end{array}$ & Criteria Group & Criteria \\
\hline & $\begin{array}{l}\text { Planning \& } \\
\text { Implementation }\end{array}$ & $\begin{array}{l}\text { - Integral Planning, Integrated Design } \\
\text { - Optimization And Complexity Of The Planning Approach } \\
\text { - Quality Of Project's Preparation } \\
\text { - Establishing Preconditions For An Optimized Use And } \\
\text { Operation } \\
\text { - Choice Of Construction Process } \\
\text { - Quality Of The Executing Contractors / Prequalification } \\
\text { - Quality Assurance Of Construction Execution } \\
\text { - Controlled Commissioning } \\
\text { - Innovations, Innovative Strategies \& Technologies } \\
\text { - Exemplary Performance } \\
\text { - Building User Guide, Awareness \& Education }\end{array}$ \\
\hline
\end{tabular}

Table 5 Process Criteria 


\subsection{Overview of Covered Criteria by Analyzed Certification Systems}

This section has two different purposes. The first is a brief introduction of the analyzed green building certification systems. The study analyzes LEED (USA), the most utilized green building certification system in the USA, and the global leading assessment method. Further, BREEAM (UK), the first established certification system worldwide, has been evaluated. The last investigated system is DGNB (Germany), representing the certification systems of the second generation. The concept of first and second generation certification systems is presented in Figure 3.

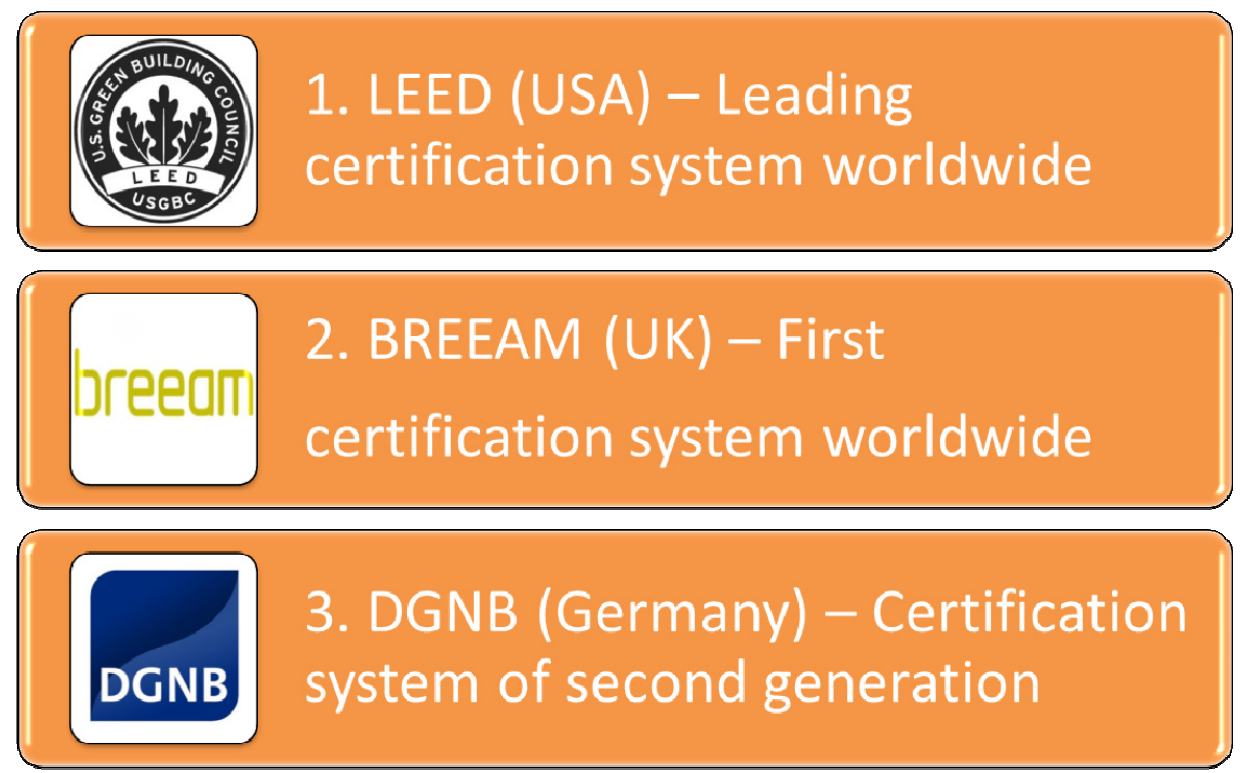

Figure 14 Overview of Analyzed Green Building Certification Systems 
The second purpose is, as the thesis title already states, to give an overview about which of the collected criteria are considered during the assessment of the selected green building certification systems. This is achieved by splitting the main criteria groups in individual tables and by using color coding to present the covered criteria. The same colors, as applied in the previous sections, are used for the different main criteria groups. The first column, called Criteria, includes all criteria that should be considered and is therefore completely colored. The white area in the three columns LEED, BREEAM, and DGNB means that those criteria are not measured by the respective certification system. The idea of using color-coding instead of showing criterion by criterion is to primarily provide an overview of covered and non-covered criteria at this point. In addition, the different analyses in this study offer a more detailed indication about which criterion is covered by the certification system and their own denominated criteria.

The figures indicate that LEED covers more environmental criteria than BREEAM or DGNB (Figure 15). Especially DGNB has a lack of covering those indicators. A more detailed analysis with regard to environmental criteria is conducted in chapter 5. Figure 16 that consider Social \& Cultural aspects reveals that all three systems have a similar degree of coverage. In addition, LEED has major weaknesses in measuring Economic issues (Figure 17); in contrast, BREEAM and DGNB almost assess all those aspects. Figures 18 and 19 disclose that LEED has a shortage of evaluating Functional \& Technical and Process criteria. In the former, BREEAM covers fewer aspects than DGNB but it has a good performance as DGNB in the latter. 


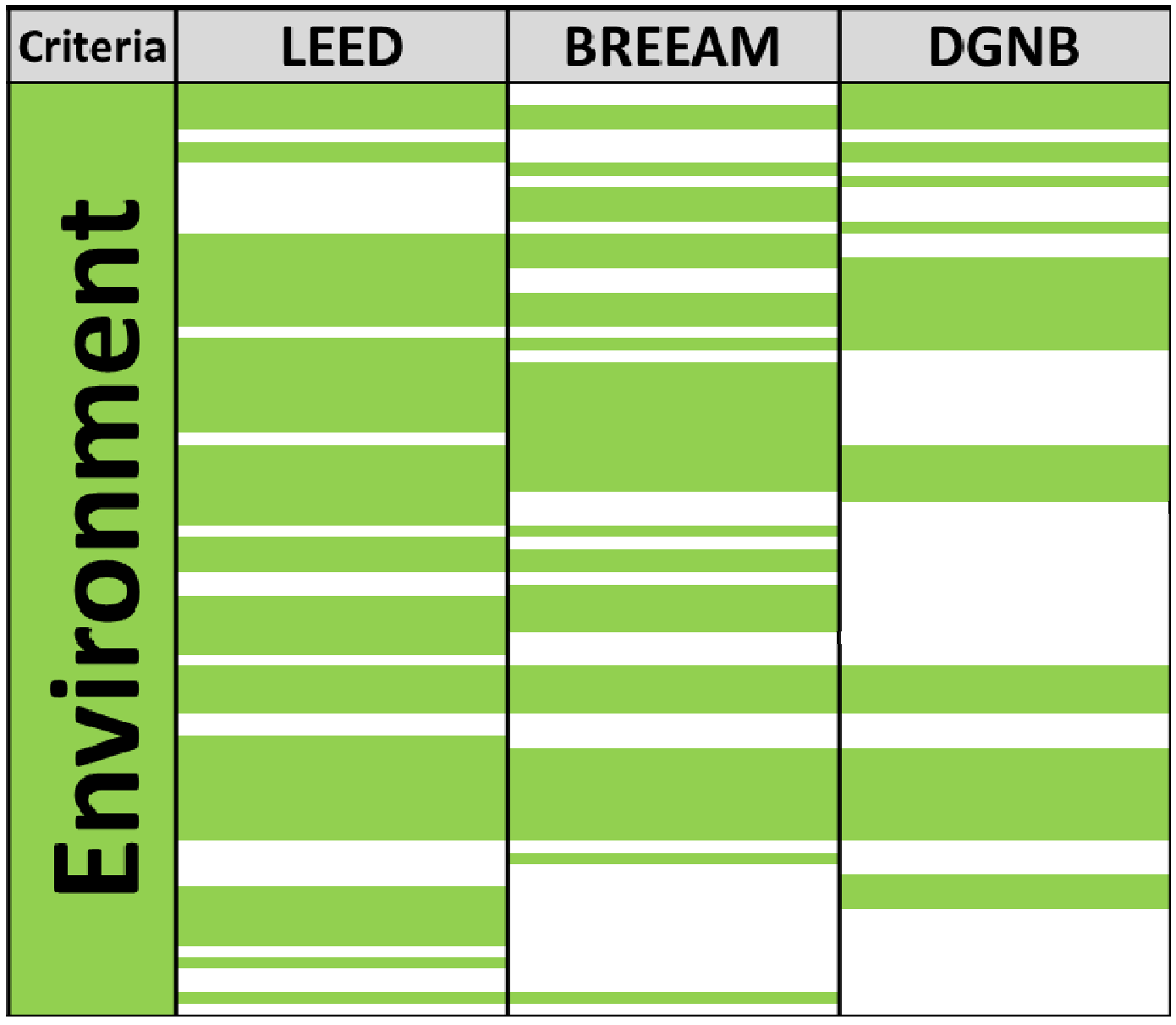

Figure 15 Covered Environmental Criteria by Selected Green Building Certification Systems

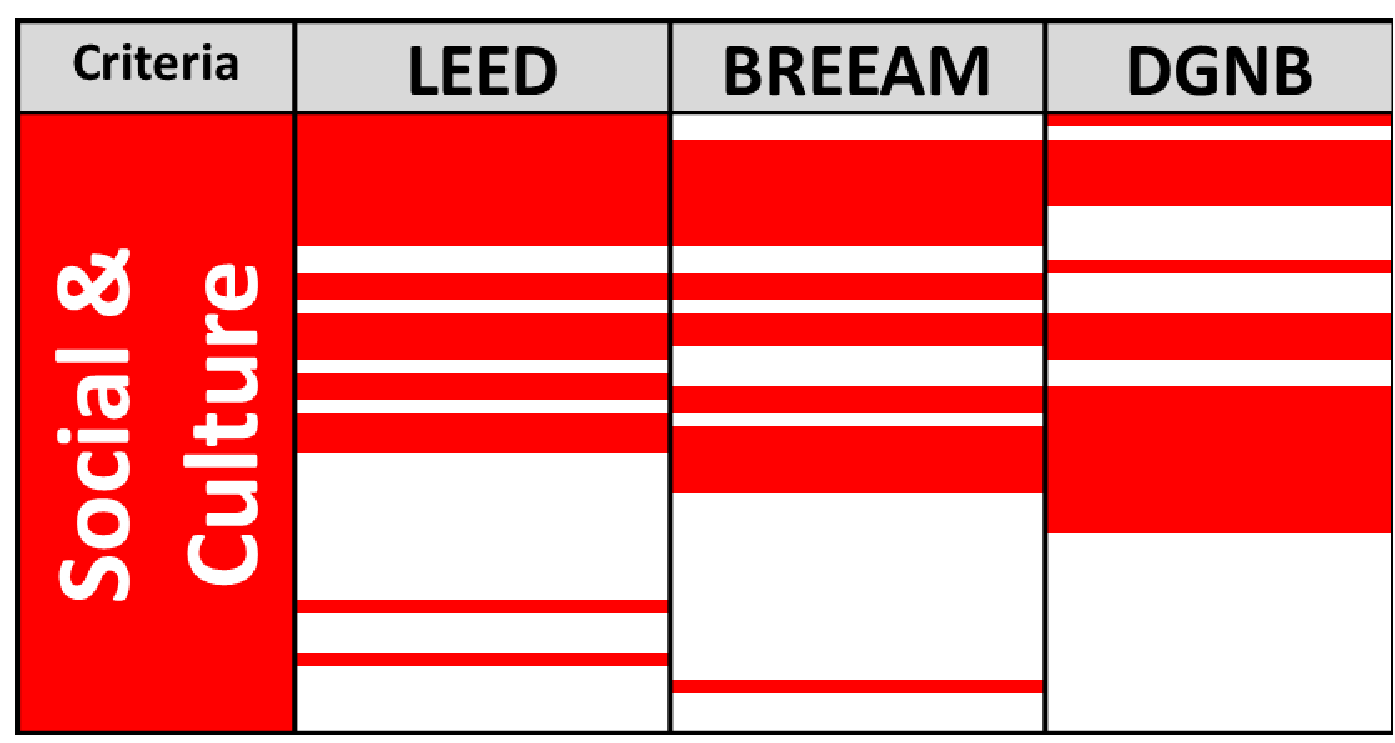

Figure 16 Covered Social \& Cultural Criteria by Selected Green Building Certification Systems 


\begin{tabular}{|c|c|c|c|}
\hline Criteria & LEED & BREEAM & DGNB \\
\hline Economic & & & \\
\hline
\end{tabular}

Figure 17 Covered Economical Criteria by Selected Green Building Certification Systems

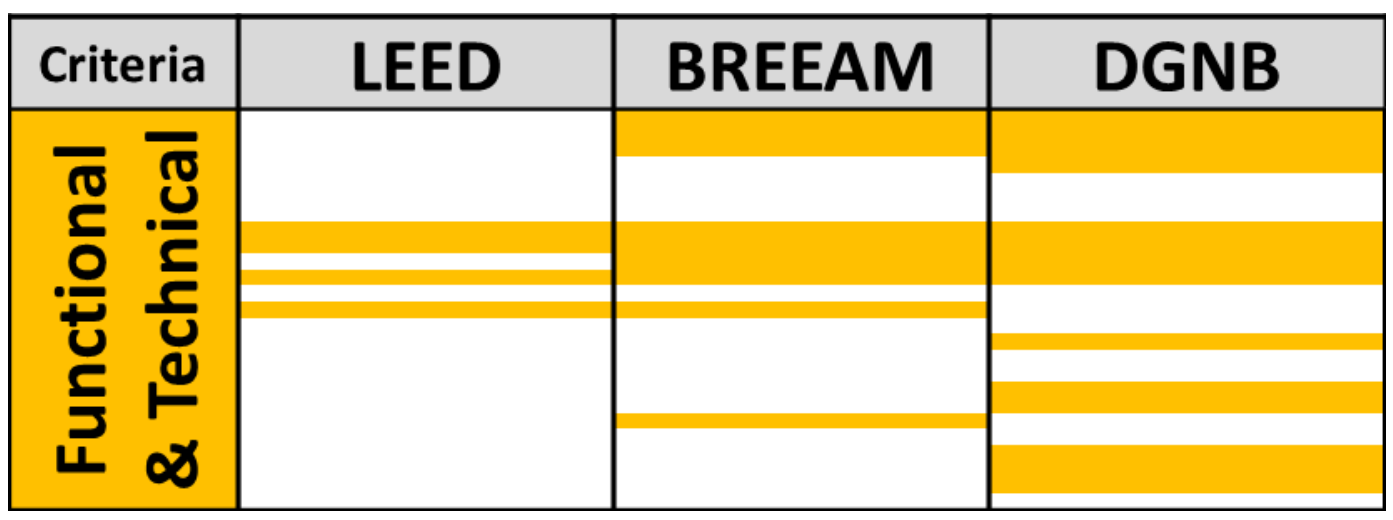

Figure 18 Covered Functional \& Technical Criteria by Selected Green Building Certification Systems

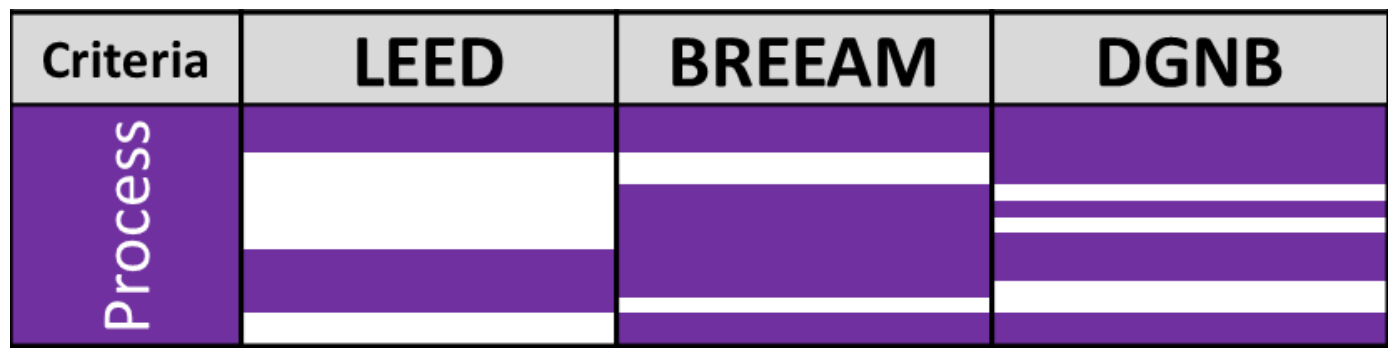

Figure 19 Covered Process Criteria by Selected Green Building Certification Systems 


\subsection{Organizing in Groups of Importance - Weighting}

Having the collected criteria organized in main groups, the question arises how to utilize them for the core purpose of the thesis: the sustainability evaluation of green building certification systems. However, since not every criterion can be seen as equally important, the weighting method should be considered in this study.

The idea of assigning points for each criterion, implemented by most certification systems, can be also applied in the course of the following evaluation process. A number will be allocated to each criterion. If the certification system covers this topic, it will receive the assigned number of points. Nonetheless, not every criterion can be considered to have an equal weight respectively the same importance. It cannot be denied that every criterion is important for building sustainability. Nevertheless, some criteria have a greater influence than others. The question is how the degree of importance for every criterion can be classified. Therefore, all criteria will be organized in the following groups of importance: "Very Important," "Important," and "Less Important." Since the term "Important" is used for each group, the reader can automatically understand the concept that no criterion should be neglected.

The procedure of assigning the criteria in the respective group of importance is based on a table set up by the organization Sustainability Performance Assessment and Benchmarking of Buildings (2010) (Table 6). Its table includes the most covered issues within the current building certification systems. However, the obvious fact that this table tends to focus on needs of a building owner is unfavorable, since present green building certification systems tend to be marketed as value increasing tools and therefore have to 
be aligned to building owners' interests. For this reason, the table was modified with the objective that building sustainability should not only serve as a marketing tool for owners, but rather, it has to contribute to the overall sustainability in the society.

\begin{tabular}{|c|c|c|}
\hline Environmental issues & Economic issues & Social issues \\
\hline $\begin{array}{ll}\text { - } & \text { Energy } \\
\text { - } & \text { Materials } \\
\text { - } & \text { Climate change } \\
\text { - } & \text { Land use and ecology } \\
\text { - } & \text { Water management }\end{array}$ & $\begin{array}{ll} & \text { Management and } \\
& \text { maintenance } \\
\text { - } & \text { Lifecycle costs } \\
\text { - } & \text { Building adaptability } \\
\text { - } & \text { Process quality } \\
\text { - Innovation }\end{array}$ & $\begin{array}{l}\text { - Comfort and health } \\
\text { - Accessibility of the } \\
\text { building and access to } \\
\text { transport } \\
\text { - Safety and security }\end{array}$ \\
\hline
\end{tabular}

Table 6 Most Covered Issues Within Current Certification Systems (SuPerBuildings, 2010)

As a result, the following color-coded tables indicate to which main criteria group (Environment, Social \& Culture etc.) each criteria group belongs to. For the purpose of identifying the main criteria group, the following stripe (Figure 20) gives an overview of the colors that are combined with the corresponding main criteria groups.

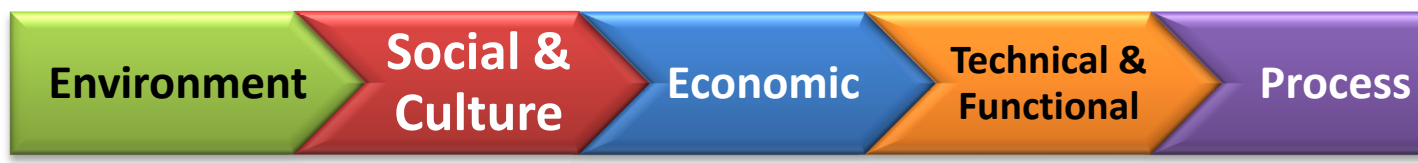

Figure 20 Color Coding for Main Criteria Groups 


\begin{tabular}{|c|c|}
\hline $\begin{array}{l}\text { Group of } \\
\text { Importance }\end{array}$ & Criteria Group \\
\hline \multirow{6}{*}{$\underline{\theta}$} & Energy \\
\hline & Materials \\
\hline & Climate Change \\
\hline & Land Use and Ecology \\
\hline & Water \\
\hline & Waste \\
\hline \multirow{6}{*}{$E$} & Life Cycle Costs \\
\hline & Building Adaptability \\
\hline & Comfort and Health \\
\hline & Accessibility of the \\
\hline & $\begin{array}{l}\text { Building and Access to } \\
\text { Transport }\end{array}$ \\
\hline & Safety and Security \\
\hline
\end{tabular}

Table 7 Very Important Criteria Groups

\begin{tabular}{|c|l|}
\hline $\begin{array}{c}\text { Group of } \\
\text { Importance }\end{array}$ & \multicolumn{1}{c|}{ Criteria Group } \\
\hline \multirow{2}{*}{} & Site Selection \\
\cline { 2 - 2 } & Aspects during Construction \\
\cline { 2 - 2 } & Management and Maintenance \\
\cline { 2 - 2 } & Process Quality \\
\cline { 2 - 2 } & Innovation \\
\cline { 2 - 2 } & Usability \\
\hline
\end{tabular}

Table 8 Important Criteria Groups

\begin{tabular}{|c|c|}
\hline $\begin{array}{c}\text { Group of } \\
\text { Importance }\end{array}$ & Criteria Group \\
\hline \multirow{5}{*}{ 总 } & Further Environmental Criteria \\
\hline & Further Indoor Environment Criteria \\
\hline & Architectural and Cultural Considerations \\
\hline & Externalities \\
\hline & Planning \& Implementation \\
\hline
\end{tabular}

Table 9 Less Important Criteria Groups 
The next paragraphs explain the different steps that lead to the point allocation of the Very Important, Important, and Less Important criteria. It contains the procedure of determining the weight for each group of importance.

\section{Step 1:}

The first step contains the combination of currently used scoring approaches of the three selected certification system in order to establish the point allocation system for the weighting process. The three certification systems require a minimum scored number of points for each certification level, e.g., LEED calls for $50 \%$ of total possible points for a "Silver" certification. The threshold percentage for receiving the highest possible certification level is not equal for each certification system. LEED requires $80 \%$, BREEAM even $85 \%$, and DGNB again $80 \%$ of the total points so that the building obtains the best possible certification level. These values are colored green in Table 10 . The same problem exists for receiving an average level certification, colored yellow in Table 10. In the case of LEED, the study uses the lower limit of the range for "Gold" certification $(60 \%)$ to represent a medium certification since BREEAM requires $55 \%$ for its average certification level "Very Good," and DGNB assigns "Silver" certification for $65 \%$. 


\begin{tabular}{|c|c|c|c|c|}
\hline \multirow{4}{*}{ LEED: } & Certified & 40-49 points & \multirow{4}{*}{$\begin{array}{c}\text { Out of } 100 \\
\text { basic points } \\
\text { (plus } 10 \text { extra } \\
\text { points) }\end{array}$} & $40-49 \%$ \\
\hline & Silver & 50-59 points & & $50-59 \%$ \\
\hline & Gold & $60-79$ points & & $60-79 \%$ \\
\hline & Platinum & $\begin{array}{l}80 \text { points and } \\
\text { above }\end{array}$ & & $80 \%$ \\
\hline \multirow{5}{*}{ BREEAM: } & Pass & & & $30 \%$ \\
\hline & Good & & & $45 \%$ \\
\hline & Very Good & & & $55 \%$ \\
\hline & Excellent & & & $70 \%$ \\
\hline & Outstanding & & & $85 \%$ \\
\hline \multirow{3}{*}{ DGNB: } & Bronze & & & $50 \%$ \\
\hline & Silver & & & $65 \%$ \\
\hline & Gold & & & $80 \%$ \\
\hline
\end{tabular}

Table 10 Combination of Current Used Scoring Approaches for Establishing the Point Allocation System

\section{Step 2:}

In this study, the threshold percentage for the highest possible certification level is determined by calculating the mean of the three different values that were colored green. As a result, this threshold percentage is $85 \%$, rounded up for simplicity:

$$
\rightarrow(80 \%+85 \%+80 \%) / 3=\approx 82 \% \rightarrow 85 \% \text { at least for very good rating level }
$$

The same procedure is applied for an average certification level. The mean of the yellow colored values result in $60 \%$ :

$\rightarrow(60 \%+55 \%+65 \%) / 3=60 \%$ at least for good rating level 
With these threshold percentages, the study has to assign the weights for each group of importance. Obviously, the Very Important criteria groups receive the highest share of points, in this case $60 \%$. The difference between the calculated $85 \%$ and $60 \%$ is assigned to the Important criteria groups. The remaining 15\% (in order to have 100\%) are allocated to the Less Important criteria groups. Therefore, the following applies:

- Weight for Very Important criteria: $\quad 60 \%$

- Weight for Important criteria: $\quad 25 \%$

- Weight for Less Important criteria: $\quad 15 \%$

\section{Step 3:}

The last step describes the point allocation for the different criteria in each criteria group. At first, the percentages are translated into points; each percentage constitutes one point. These points (60 points, 25 points, 15 points) are allocated to the different criteria groups. There are 11 Very Important criteria groups (Table 7), 6 Important criteria groups (Table 8), and 5 Less Important criteria groups (Table 9). As a result, the following point allocation occurs:

11 Very Important criteria groups: 60 points $\rightarrow 5.5$ points for each group 6 Important criteria groups: $\quad 25$ points $\rightarrow 4.2$ points for each group

5 Less Important criteria groups: $\quad 15$ points $\rightarrow 3.0$ points for each group 
However, since the Very Important criteria group contains by far the majority of all criteria, each of its criteria would be allocated fewer points than for Important and Less Important criteria. Therefore, the ratio of numbers of criteria between each criteria group has to be considered and translated into the point allocation procedure. The ratio between the number of Very Important, Important, and Less Important criteria is approximately 22 $: 7: 3$. Multiplying these values with the number of its respective groups result in the ratio $242: 42: 15$, which presents a more meaningful relationship between the three criteria groups. As the sum yield in almost 300 (299) points, each number is divided by three to have a total score of 100 points. For simplicity, the number for Very Important criteria was rounded down and for Important criteria rounded up. It means that 80 points are assigned to Very Important criteria, 15 points to Important criteria, and 5 points to Less Important criteria.

\begin{tabular}{|c|c|c|c|c|}
\hline & & & & \multicolumn{1}{c|}{ Round up / down } \\
\hline Very important & 22 & 242 & 81 & 80 \\
\hline Important & 7 & 42 & 14 & 15 \\
\hline Less Important & 3 & 15 & 5 & 5 \\
\hline
\end{tabular}

Table 11 Calculations Steps for Establishing the Point Allocation System 
Finally, due to the fact that the entire 100 points cannot be evenly distributed because of the uneven number of criteria, the study determines the following point allocation for each criterion, which results in a total score of 96 points:

- Very Important Criterion: 1 point

- Important Criterion: $\quad 0.5$ points

- Less Important Criterion: 0.25 points 
Chapter 4 Analyzing Current Focus of Green Building Certification Systems

\subsection{Introduction}

This chapter deals with the first analysis of the selected green building certification systems. The purpose of the analysis is to demonstrate the various emphases on subjects each system currently places. The categories applied for the evaluation are a combination of the sections presently used by the three certification systems. LEED and its sections served as the foundation. The additional sections covered by the two remaining certification systems were summarized and/or added. Table 12 shows all categories used for the analysis and their formation.

\begin{tabular}{|c|c|c|c|}
\hline Categories & LEED & BREEAM & DGNB \\
\hline Sustainable Sites & Sustainable Sites & - & - \\
\hline Water Efficiency & Water Efficiency & - & - \\
\hline $\begin{array}{l}\text { Energy and } \\
\text { Atmosphere }\end{array}$ & $\begin{array}{l}\text { Energy and } \\
\text { Atmosphere }\end{array}$ & - & - \\
\hline $\begin{array}{l}\text { Materials and } \\
\text { Resources }\end{array}$ & $\begin{array}{l}\text { Materials and } \\
\text { Resources }\end{array}$ & - & - \\
\hline $\begin{array}{l}\text { Indoor } \\
\text { Environment } \\
\text { Quality }\end{array}$ & $\begin{array}{l}\text { Indoor } \\
\text { Environment } \\
\text { Quality }\end{array}$ & - & - \\
\hline $\begin{array}{l}\text { Innovation and } \\
\text { Design Process }\end{array}$ & $\begin{array}{l}\text { Innovation and } \\
\text { Design Process }\end{array}$ & - & - \\
\hline $\begin{array}{l}\text { Regional Priority } \\
\text { Credits }\end{array}$ & $\begin{array}{l}\text { Regional Priority } \\
\text { Credits }\end{array}$ & - & - \\
\hline $\begin{array}{l}\text { Construction and } \\
\text { Management }\end{array}$ & - & Management & Construction \\
\hline Life Cycle Costs & - & - & $\begin{array}{l}\text { - Life Cycle Cost } \\
\text { - Progress of Value }\end{array}$ \\
\hline Technical Aspects & - & - & Technical Quality \\
\hline
\end{tabular}

Table 12 Formation of Benchmark Categories 
The analysis is separated for each system. Also, the evaluation is performed individually by each criteria group and presented in a table (Table 13-15, Appendix A). The comparison was implemented with the average percentage of contribution to the overall score a group has for each green building certification system. An average percentage was calculated for the different types of buildings a system certifies, such as office buildings, retail or education buildings. Under the average percentage the range of the percentages is shown. In the case of identical values for each type of project, no range had to be provided. During the analysis of BREEAM and DGNB, their associated sections were compared to the benchmark groups. LEED provides the majority of those benchmark groups, and as a result, no extra column for listing its own sections as comparison is necessary. In the case of LEED, the first column names the benchmark group, the second column shows the criteria involved, and the last column presents the average percentage contribution to the overall score. For BREEAM and DGNB, an additional column for their own termed sections is provided after the first column.

The following tables (Tables 13-15) show one example calculation about the used concept to compare the Green Building Certification Systems. An average percentage contribution to overall score was determined in order to demonstrate the various emphases on subjects each system currently places. This score describes the extent of influence each category has to the total score. The study uses the category Water Efficiency as a sample: 


\begin{tabular}{|l|c|}
\hline \multicolumn{1}{|c|}{ Project Type } & $\begin{array}{c}\text { Percentage } \\
\text { Contribution to } \\
\text { Overall Score }\end{array}$ \\
\hline New Construction & $9.1 \%$ \\
\hline Schools & $10.0 \%$ \\
\hline Retail & $9.1 \%$ \\
\hline Healthcare & $8.2 \%$ \\
\hline Average & $\mathbf{9 . 1 \%}$ \\
\hline
\end{tabular}

Table 13 Example of Calculating Percentage Contribution with LEED

\begin{tabular}{|l|c|}
\hline \multicolumn{1}{|c|}{ Project Type } & $\begin{array}{c}\text { Percentage } \\
\text { Contribution to } \\
\text { Overall Score }\end{array}$ \\
\hline Office & $6.0 \%$ \\
\hline Retail & $6.0 \%$ \\
\hline Industrial & $6.0 \%$ \\
\hline Healthcare & $6.0 \%$ \\
\hline School & $6.0 \%$ \\
\hline Higher Education & $6.0 \%$ \\
\hline Prisons & $6.0 \%$ \\
\hline Courts & $6.0 \%$ \\
\hline Mulitresidential & $6.0 \%$ \\
\hline Other buildings & $6.0 \%$ \\
\hline Average & $\mathbf{6 . 0 \%}$ \\
\hline
\end{tabular}

Table 14 Example of Calculating Percentage Contribution with BREEAM 


\begin{tabular}{|l|c|}
\hline \multicolumn{1}{|c|}{ Project Type } & $\begin{array}{c}\text { Percentage } \\
\text { Contribution to } \\
\text { Overall Score }\end{array}$ \\
\hline Office & $\begin{array}{c}0 \% \\
\text { (Considered } \\
\text { Education }\end{array}$ \\
\hline Hotel & $\begin{array}{c}\text { partially in DGNB } \\
\text { category } \\
\text { "Resources and } \\
\text { Waste") }\end{array}$ \\
\hline Industrial & $\mathbf{0 . 0 \%}$ \\
\hline Mulitresidential & Retail \\
\hline Average & \\
\hline
\end{tabular}

Table 15 Example of Calculating Percentage Contribution with DGNB

The following sections illustrate the analysis by giving samples tables (section 4.2) and a summary table and charts for a comparable overview of the performance of each system (section 4.3). 


\subsection{Analysis}

Tables 9-11 provide an example about how the analysis was structured and implemented for each certification system. The complete set of tables of the analysis can be reviewed in Appendix A. The category "Water Efficiency" is demonstrated for each Green Building Certification System. Table 9 provides the criteria that LEED considers for assessing "Water Efficiency". The 6 criteria have an average percentage contribution of 9.1\% to the overall score. It means that almost every tenth point of the total assessment refers to "Water Efficiency." An average value was calculated since LEED has different assessment systems with dissimilar weightings for several types of buildings. For this reason, the range for the various contributions is also displayed for illustrative purposes. In contrast, BREEAM considers only four criteria for the evaluation of Water Efficiency. For comparison, Table 10 also presents in its second column the category title "Water" instead of "Water Efficiency," in which BREEAM includes the criteria to measure the same or similar indicators as LEED does. For BREEAM, this category is relatively less important in comparison with LEED, due to the fact that only $6 \%$ of the overall score is influenced by those criteria. In the case of BREEAM, all different building types have the same value for this category and therefore, a range need not to be shown. The last sample table, showing the analysis with DGNB, identifies that this certification system does not integrate an own category with regard to "Water Efficiency." Only individual criteria, incorporated in DGNB's own category "Resources and Waste", assess partial aspects of "Water Efficiency." As a result, the average percentage contribution to the overall score here is $0 \%$. 


\begin{tabular}{|c|c|c|}
\hline Category & Criterion & $\begin{array}{c}\text { Average } \\
\text { Percentage } \\
\text { Contribution to } \\
\text { Overall Score }\end{array}$ \\
\hline \multirow{6}{*}{ 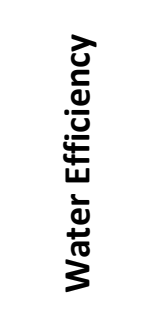 } & Water Use Reduction - 20\% Reduction & \multirow{6}{*}{$\begin{array}{c}9.1 \% \\
(8.20 \%- \\
10.00 \%)\end{array}$} \\
\hline & Minimize Potable Water Use for Medical Equipment Cooling & \\
\hline & Water Efficient Landscaping & \\
\hline & Innovative Waste Water Technologies & \\
\hline & Water Use Reduction & \\
\hline & Process Water Use Reduction & \\
\hline
\end{tabular}

Table 16 Sample Table for the Analysis by Current Used Categories with LEED

\begin{tabular}{|c|c|c|c|}
\hline Category & $\begin{array}{l}\text { Category } \\
\text { BREEAM }\end{array}$ & Criterion & $\begin{array}{c}\text { Average } \\
\text { Percentage } \\
\text { Contribution to } \\
\text { Overall Score }\end{array}$ \\
\hline \multirow{4}{*}{ 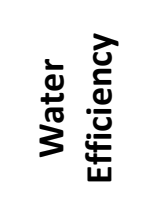 } & \multirow{4}{*}{$\begin{array}{l}\frac{1}{ \pm} \\
\stackrel{\pi}{\pi} \\
3\end{array}$} & Water Consumption & \multirow{4}{*}{$6.00 \%$} \\
\hline & & Water Monitoring & \\
\hline & & Water Leak Detection and Prevention & \\
\hline & & Water Efficient Equipment & \\
\hline
\end{tabular}

Table 17 Sample Table for the Analysis by Current Used Categories with BREEAM

\begin{tabular}{|c|c|c|c|}
\hline Category & $\begin{array}{c}\text { Category } \\
\text { DGNB }\end{array}$ & Criterion & $\begin{array}{c}\text { Average } \\
\text { Percentage } \\
\text { Contribution to } \\
\text { Overall Score }\end{array}$ \\
\hline 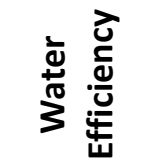 & - & Considered partially in "Resources and Waste" & $0.00 \%$ \\
\hline
\end{tabular}

Table 18 Sample Table for the Analysis by Current Used Categories with DGNB 


\subsection{Discussion}

The summary table indicates which categories the individual green building certification system emphasizes. Noticeable is the similarity of the emphasis of both LEED and BREEAM. Each system gives the categories Sustainable Sites, Energy and Atmosphere, Materials and Resources, and Indoor Environment Quality a high weighting. Additional resemblance is shown in the categories Water Efficiency. Both systems do not establish an own group for Life Cycle Costs and Technical Aspects, whereas the topics are more or less considered in individual criteria by each system. In contrast, DGNB emphasizes the categories Life Cycle Costs and Technical Aspects. An exculpation for DGNB regarding the category Sustainable Sites is, for which its section "Quality of Location" would be also considered, that this section is measured individually and thus does not contribute to the building's overall score. Other important but secondary categories are Energy and Atmosphere, Materials and Resources, Indoor Environment Quality, and Innovation and Design Process. LEED, in opposition to BREEAM and DGNB, does not establish categories for Construction or Management. These categories are only partially considered by a few criteria. At the same time BREEAM and DGNB do not assign Regional Priority Credits.

As a result, we can see the major differences in emphasizing the categories especially between LEED and BREEAM to DGNB. Nevertheless, none of the three systems can claim to be the best compiled green building certification system. All have strengths and weaknesses; however, each misses or undervalues certain important categories. 


\begin{tabular}{|c|c|c|c|}
\hline Category & LEED & BREEAM & DGNB \\
\hline Sustainable Sites & $21.35 \%$ & $18.02 \%$ & $4.13 \% *$ \\
\hline Water Efficiency & $9.10 \%$ & $6.00 \%$ & $0.00 \%$ \\
\hline Energy and Atmosphere & $32.28 \%$ & $28.99 \%$ & $12.03 \%$ \\
\hline Materials and Resources & $12.93 \%$ & $20.15 \%$ & $10.53 \%$ \\
\hline Indoor Environment Quality & $15.23 \%$ & $15.00 \%$ & $13.80 \%$ \\
\hline Innovation and Design Process & $5.50 \%$ & $10.00 \%$ & $10.67 \%$ \\
\hline Regional Priority Credits & $3.60 \%$ & $0.00 \%$ & $0.00 \%$ \\
\hline Construction and Management & $0.00 \%$ & $12.00 \%$ & $3.80 \%$ \\
\hline Life Cycle Costs & $0.00 \%$ & $0.00 \%$ & $22.53 \%$ \\
\hline Technical Aspects & $0.00 \%$ & $0.00 \%$ & $22.52 \%$ \\
\hline Total & $100.00 \%$ & $\begin{array}{l}\quad 110.00 \% \\
(10 \% \text { for } \\
\text { Innovation } \\
\text { considered } \\
\text { as extra } \\
\text { points) }\end{array}$ & $\begin{array}{l}\quad 100.00 \% \\
\text { * The } \\
\text { section } \\
\text { "Quality of } \\
\text { Location" is } \\
\text { measured } \\
\text { individually } \\
\text { by DGNB. }\end{array}$ \\
\hline
\end{tabular}

Table 19 Summary Table for Analysis of LEED, BREEAM, and DGNB by Current Used Categories

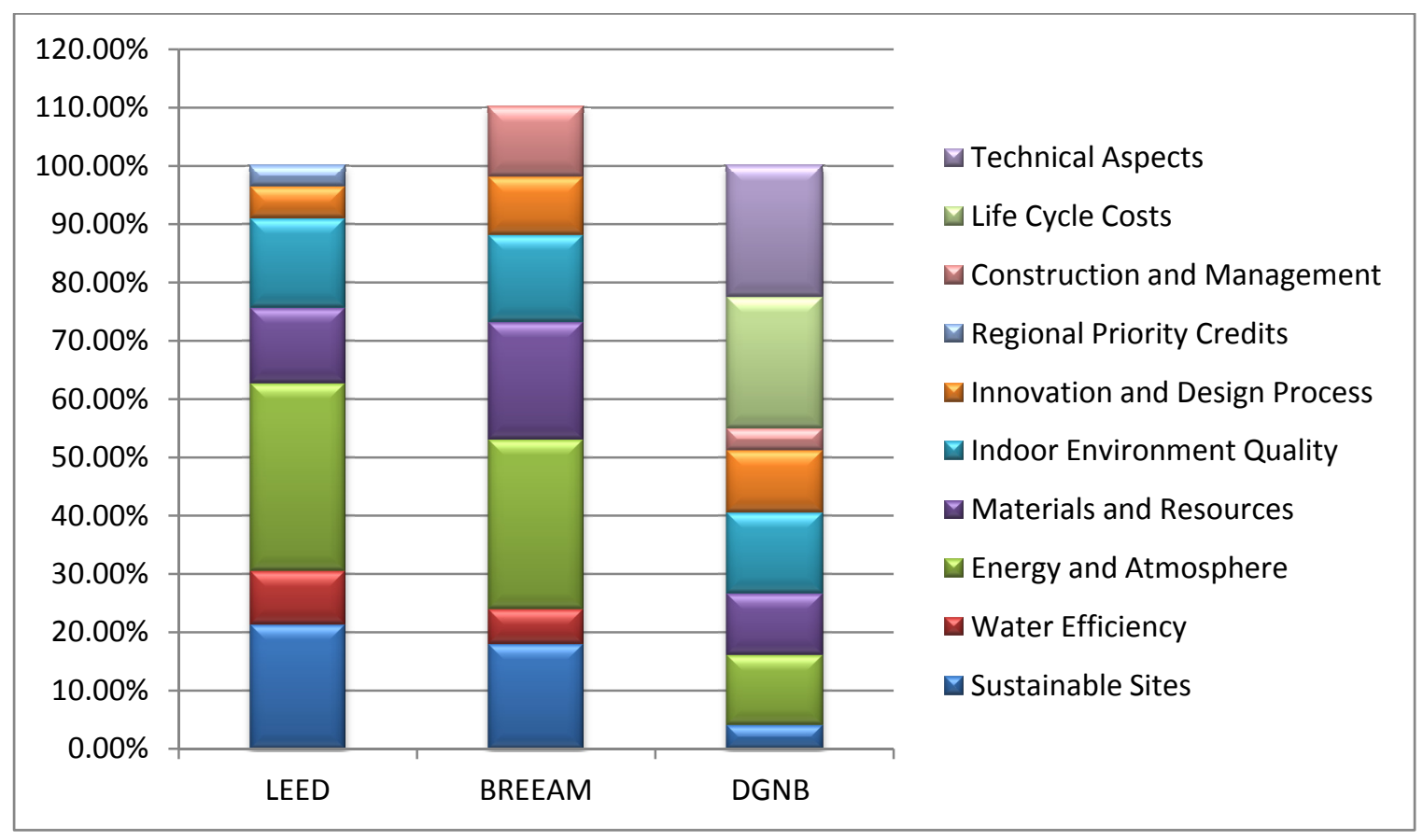

Figure 21 Comparison of LEED, BREEAM, and DGNB by Current Used Categories 


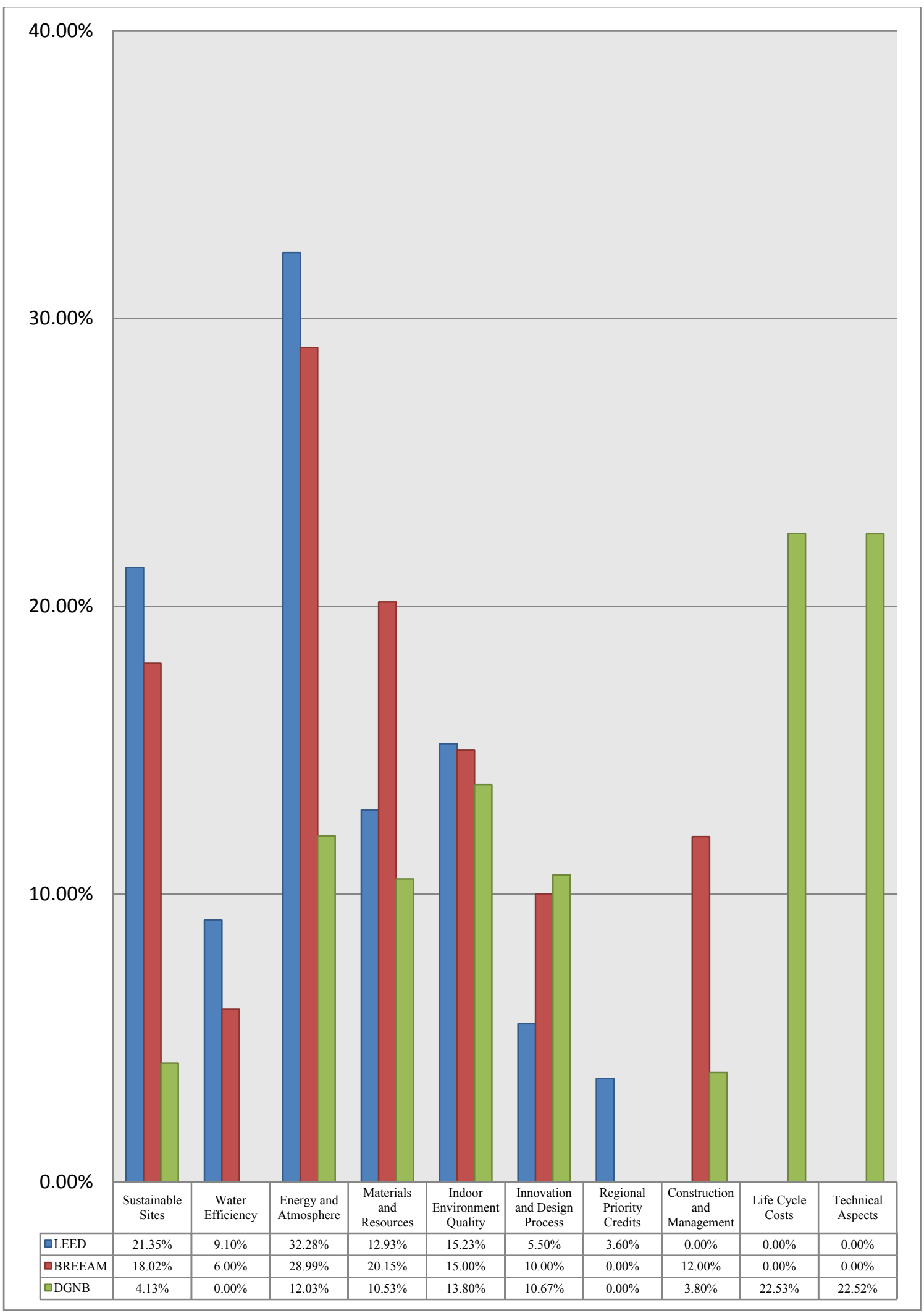

Figure 22 Comparison of LEED, BREEAM, and DGNB by Current Used Categories 
Chapter 5 Analyzing the Environmental Performance of Green Building Certification Systems

\subsection{Introduction}

This chapter contains the second type of analysis. Only the environmental criteria that were collected but not weighted were applied for this evaluation of the Green Building Certification Systems. The purpose of the analysis is to disclose how "Green" the respective certification system is. Section 3.3 could already indicate the difference between the coverage by each certification system. This chapter implies a more descriptive quantitative analysis by using a scoring system.

The analysis is once again separated for each certification system, implemented individually by each environmental subgroup, and outlined in tables (Appendix B). The possible points for an environmental criterion, for the matter of simplicity 1 point for each criterion, are presented on the left side of the table. On the right side are the existing criteria which are included in the current certification systems and cover the respective criterion, the category provided in the certification system in which the existing criterion is integrated, and the points scored by the analyzed system.

Section 5.2 illustrates the analysis by giving sample tables. Section 5.3 implies the summary table and charts that demonstrate the performance by each system. 


\subsection{Analysis}

This section also makes sample tables available (Tables 13-15) in order to describe the environmental analysis. Appendix B contains the entire set of tables of the environmental analysis. In this case, the category "Land Use" is provided for every Green Building Certification System. Table 13 demonstrates the criteria that LEED involves in its assessment process for this type of category. The criteria "Green Field / Brown Field" and "Land Regeneration \& Development" are established as the indicators that have to be examined for this criteria group. For the former, LEED has a criterion with a similar title called "Brownfield Development." Therefore, LEED receives the assigned 1 point. For the latter, LEED has two different criteria that deal with it, "Alternative Transportation Low-Emitting and Fuel-Efficient Vehicles" and "Alternative Transportation - Parking Capacity." This also results in obtaining the assigned point. All three criteria are included in LEED's own category, "Sustainable Sites." It appears as well that Green Building Certification System's criteria, that jointly cover a criterion, are separated in different categories since each certification system defines its group by its own classification. BREEAM achieves only 1 point for "Green Field / Brown Field" by its criterion "Site Selection," which is incorporated in the category "Land Use and Ecology." BREEAM does not have any criterion that assesses the subject "Land Regeneration \& Development." The final sample table in this section indicates that DGNB collects both individual points by only one criterion, namely "Land Use," that is a part of the criteria group "Resources and Waste." 


\begin{tabular}{|c|c|c|c|c|c|}
\hline $\begin{array}{l}\text { Criteria } \\
\text { Group }\end{array}$ & Criteria & $\begin{array}{l}\text { Possible } \\
\text { Points }\end{array}$ & Title Criterion & $\begin{array}{l}\text { In Category } \\
\text { Included }\end{array}$ & Score \\
\hline \multirow[b]{2}{*}{$\begin{array}{c}0 \\
0 \\
0 \\
0\end{array}$} & Green Field / Brown Field & 1 & $\begin{array}{l}\text { - Brownfield } \\
\text { Development }\end{array}$ & $\begin{array}{l}\text { Sustainable } \\
\text { Sites }\end{array}$ & 1 \\
\hline & $\begin{array}{l}\text { Land Regeneration \& } \\
\text { Development }\end{array}$ & 1 & $\begin{array}{l}\text { - Alternative } \\
\text { Transportation - } \\
\text { Low-Emitting and } \\
\text { Fuel-Efficient } \\
\text { Vehicles } \\
\text { - Alternative } \\
\text { Transportation - } \\
\text { Parking Capacity }\end{array}$ & $\begin{array}{l}\text { Sustainable } \\
\text { Sites }\end{array}$ & 1 \\
\hline
\end{tabular}

Table 20 Sample Table for the Analysis by Environmental Criteria with LEED

\begin{tabular}{|c|c|c|c|c|c|}
\hline $\begin{array}{c}\text { Criteria } \\
\text { Group }\end{array}$ & \multicolumn{1}{|c|}{ Criteria } & $\begin{array}{c}\text { Possible } \\
\text { Points }\end{array}$ & Title Criterion & $\begin{array}{c}\text { In Category } \\
\text { Included }\end{array}$ & Score \\
\hline \multirow{2}{*}{0} & Green Field / Brown Field & $\mathbf{1}$ & - Site Selection & $\begin{array}{c}\text { Land Use } \\
\text { and Ecology }\end{array}$ & 1 \\
\cline { 2 - 6 } & $\begin{array}{l}\text { Land Regeneration \& } \\
\text { Development }\end{array}$ & $\mathbf{1}$ & - & - & 0 \\
\hline
\end{tabular}

Table 21 Sample Table for the Analysis by Environmental Criteria with BREEAM

\begin{tabular}{|c|c|c|c|c|c|}
\hline $\begin{array}{l}\text { Criteria } \\
\text { Group }\end{array}$ & Criteria & $\begin{array}{l}\text { Possible } \\
\text { Points }\end{array}$ & Title Criterion & $\begin{array}{l}\text { In Category } \\
\text { Included }\end{array}$ & Score \\
\hline \multirow{2}{*}{ 동 } & Green Field / Brown Field & 1 & \multirow[b]{2}{*}{ - Land Use } & \multirow{2}{*}{$\begin{array}{l}\text { Resources } \\
\text { and Waste }\end{array}$} & 1 \\
\hline & $\begin{array}{l}\text { Land Regeneration \& } \\
\text { Development }\end{array}$ & 1 & & & 1 \\
\hline
\end{tabular}

Table 22 Sample Table for the Analysis by Current Used Categories with DGNB 


\subsection{Discussion}

The summary table for the "environmental" analysis shows to what exent the environmental assessment goes by each certification systems. This evaluation classifies LEED as the system that considers more environmental criteria than BREEAM or DGNB. Contrastingly, DGNB neglects to assess the environmental performance of a building. However, LEED does not lead in all individual categories. It scored only in "Land Use" (together with DGNB), "Water Use," "Materials \& Components," and

"Waste" the highest number of points. BREEAM captured the categories "Biodiversity" and "Resource Depletion," whereby DGNB additionally ranked first in "Site Selection" and "Emissions."

Noticeable is the missing assessment of "Waste" by DGNB. This may be based on the fact that the topic "Waste" is highly sophisticated in Germany. According to the OECD (2005), Germany counts as one of the countries with the highest value of recycling and lowest rate of incineration of waste. Therefore, the German certification system DGNB may assume that this matter is already sufficiently controlled by policies and regulations. Against this background, with the generally sophisticated regulation of recycling in Germany, the negative score in "Materials \& Components" may also be explained.

All three systems cannot assert to sufficiently assess the environmental performance of a green building. To predicate its certification system as a "Green Building Program" (USGBC for LEED) or the "Environmental Assessment Method" (BRE for BREEAM) but scoring in this analysis around (LEED) or less than half of possible points (BREEAM and DGNB), it leads to doubt about the credibility. 


\begin{tabular}{|c|c|c|c|c|}
\hline Category & $\begin{array}{c}\text { Possible } \\
\text { Points }\end{array}$ & LEED & BREEAM & DGNB \\
\hline Site Selection & 6 & 3 & 2 & 4 \\
\hline Biodiversity & 4 & 2 & 3 & 1 \\
\hline Land Use & 2 & 2 & 1 & 2 \\
\hline Resource Depletion & 6 & 3.5 & 4 & 3 \\
\hline Water Use & 8 & 5 & 4 & 2 \\
\hline Materials \& Components & 6 & 3 & 2 & 1 \\
\hline Emissions & 7 & 2.5 & 2 & 3 \\
\hline Waste & 6 & 2 & 1 & 0 \\
\hline Total & 45 & 23 & 19 & 16 \\
\hline
\end{tabular}

Table 23 Summary Table for Analysis of LEED, BREEAM, and DGNB by Environmental Criteria 


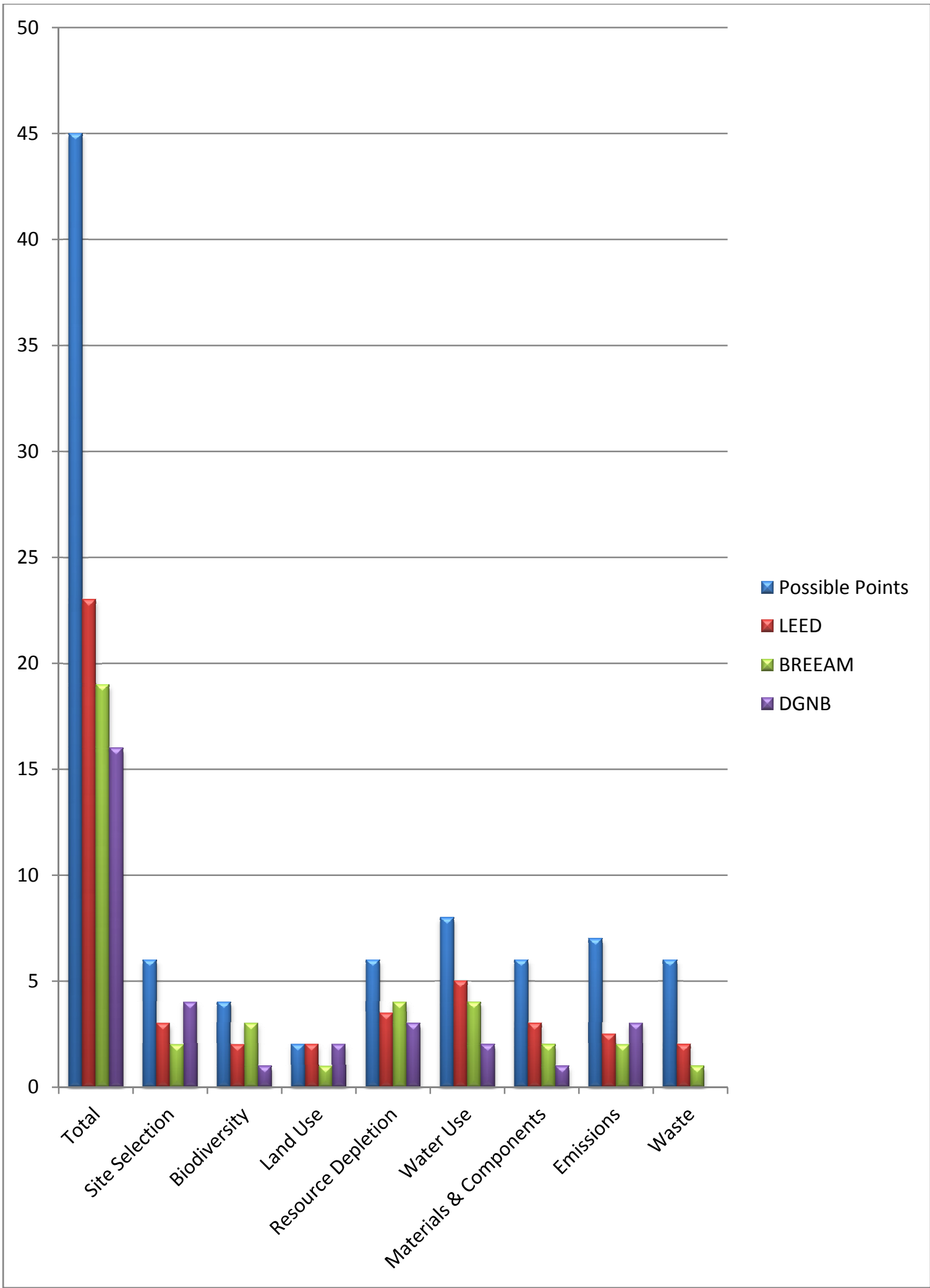

Figure 23 Comparison of LEED, BREEAM, and DGNB by Environmental Criteria 
Chapter 6 Evaluating the Sustainable Performance of Green Building Certification Systems

\subsection{Introduction}

This chapter contains a third method of analysis of the selected certification systems. It deals with the main purpose of the study, the Sustainability Evaluation of Green Building Certification Systems. As already stated in section 1.2, any certification system varies and differently illustrates building sustainability. This analysis tries to disclose which aspects of the different main criteria groups (Environment, Social \& Cultural, Economic, Functional \& Technical, and Process) are considered and particular to which extent they are involved in the assessment process by the three Green Building Certification Systems. It is based on the three groups of importance that are set up in chapter 3. The analysis (Appendix C) is separated for each system. In addition, the evaluation is performed individually by each criteria group and presented in a table. The possible points for each criterion are presented on the left side of the table. On the right side are the existing criteria, which are included in the current certification systems and cover the respective criterion. On the same side are also listed the category provided in the certification system in which the existing criterion is integrated, and the points scored by the analyzed system. If the achieved score represents only half of the possible points, it means that the required criterion is not fully satisfied by the criterion existing in the certification system. In section 6.2 , the summary table and charts give comparable overviews of the performance of each system. The point allocation for the three different weighting categories is arranged as follows (see section 3.2): 
- Very Important Criterion: 1 point

- Important Criterion: $\quad 0.5$ points

- Less Important Criterion: 0.25 points

Appendix E provides the different steps of the development of the point allocation. 


\subsection{Analysis}

Tables 17-19 serve as samples for the analysis by weighted criteria. Appendix C encompasses the total set of tables for this analysis. In this example, the assessment of the category "Accessibility of the Building and Access to Transport" of the Main Criteria Group "Social \& Culture" is presented. The following criteria should be covered by a Green Building Certification System to earn the total score: "Public \& Public Transport Accessibility", "Barrier-Free Accessibility", "Bicycle Comfort", "Pedestrian Comfort," and "Car Parking Capacity". Table 17 discloses the criteria that LEED considers for its evaluation process. It is noticeable that LEED's criteria, which partially cover the weighted criteria, entirely come from its group "Sustainable Sites". LEED cannot score the total number of points since it does not assess the subjects "Pedestrian Comfort," and the especially in the USA very important issue, "Barrier-Free Accessibility". This results in only $60 \%$ coverage of total possible points. On the other hand, BREEAM achieves $80 \%$ of the entire score. Three of BREEAM's criteria belong to its group "Transport" and one criteria stems from "Management." Two individual criteria, "Public Transport Accessibility" and "Travel Plan", deal with "Public \& Public Transport Accessibility". DGNB's performance in this part of the analysis is similar to LEED. Also, only $60 \%$ of possible points are scored, but with the difference that DGNB evaluates "Barrier-Free Accessibility" and ignores "Car Parking Capacity". Likewise, as BREEAM, DGNB's criteria exist from two different groups and two separate criteria, "Public Accessibility" and "Transport Accessibility", covering "Public \& Public Transport Accessibility". 


\begin{tabular}{|c|c|c|c|c|c|}
\hline $\begin{array}{l}\text { Criteria } \\
\text { Group }\end{array}$ & Criteria & $\begin{array}{c}\text { Possible } \\
\text { Points }\end{array}$ & Title Criterion & $\begin{array}{l}\text { In Category } \\
\text { Included }\end{array}$ & Score \\
\hline \multirow{5}{*}{ 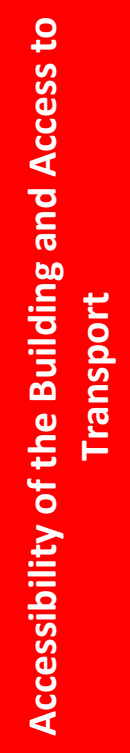 } & $\begin{array}{l}\text { Public \& Public } \\
\text { Transport Accessibility }\end{array}$ & 1 & $\begin{array}{l}\text { - Alternative } \\
\text { Transportation - } \\
\text { Public } \\
\text { Transportation } \\
\text { Access }\end{array}$ & $\begin{array}{l}\text { Sustainable } \\
\text { Sites }\end{array}$ & 1 \\
\hline & $\begin{array}{l}\text { Barrier-Free } \\
\text { Accessibility }\end{array}$ & 1 & - & - & 0 \\
\hline & Bicycle Comfort & 1 & $\begin{array}{l}\text { - Alternative } \\
\text { Transportation - } \\
\text { Bicycle Storage } \\
\text { and Changing } \\
\text { Rooms } \\
\end{array}$ & $\begin{array}{l}\text { Sustainable } \\
\text { Sites }\end{array}$ & 1 \\
\hline & Pedestrian Comfort & 1 & - & - & 0 \\
\hline & Car Parking Capacity & 1 & $\begin{array}{l}\text { - Alternative } \\
\text { Transportation - } \\
\text { Parking Capacity }\end{array}$ & $\begin{array}{l}\text { Sustainable } \\
\text { Sites }\end{array}$ & 1 \\
\hline
\end{tabular}

Table 24 Sample Table for the Analysis by Weighted Criteria with LEED

\begin{tabular}{|c|c|c|c|c|c|}
\hline $\begin{array}{l}\text { Criteria } \\
\text { Group }\end{array}$ & Criteria & $\begin{array}{l}\text { Possible } \\
\text { Points }\end{array}$ & Title Criterion & $\begin{array}{l}\text { In Category } \\
\text { Included }\end{array}$ & Score \\
\hline \multirow{6}{*}{ 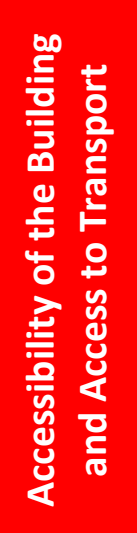 } & Public \& Public & 1 & $\begin{array}{l}\text { - Public Transport } \\
\text { Accessibility }\end{array}$ & \multirow[t]{2}{*}{ Transport } & \multirow[t]{2}{*}{1} \\
\hline & Iransport Accessidility & & - Travel Plan & & \\
\hline & $\begin{array}{l}\text { Barrier-Free } \\
\text { Accessibility }\end{array}$ & 1 & $\begin{array}{l}\text { - Stakeholder } \\
\text { Participation - } \\
\text { Inclusive and } \\
\text { Accessible Design }\end{array}$ & Management & 1 \\
\hline & Bicycle Comfort & 1 & - Cyclist Facilities & Transport & 1 \\
\hline & Pedestrian Comfort & 1 & - & - & 0 \\
\hline & Car Parking Capacity & 1 & $\begin{array}{l}\text { - Maximum Car } \\
\text { Parking Capacity }\end{array}$ & Transport & 1 \\
\hline
\end{tabular}

Table 25 Sample Table for the Analysis by Weighted Criteria with BREEAM 


\begin{tabular}{|c|c|c|c|c|c|}
\hline $\begin{array}{l}\text { Criteria } \\
\text { Group }\end{array}$ & Criteria & $\begin{array}{l}\text { Possible } \\
\text { Points }\end{array}$ & Title Criterion & $\begin{array}{l}\text { In Category } \\
\text { Included }\end{array}$ & Score \\
\hline \multirow{6}{*}{ 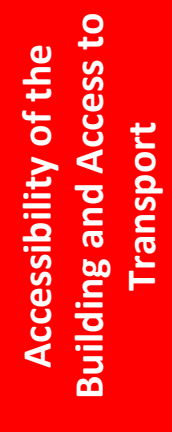 } & Public \& Public & & - Public Accessibility & Functionality & \multirow{2}{*}{1} \\
\hline & Transport Accessibility & 1 & $\begin{array}{l}\text { - Transport } \\
\text { Accessibility }\end{array}$ & $\begin{array}{l}\text { Quality of } \\
\text { Location }\end{array}$ & \\
\hline & $\begin{array}{l}\text { Barrier-Free } \\
\text { Accessibility }\end{array}$ & 1 & $\begin{array}{l}\text { - Barrier-Free } \\
\text { Accessibility }\end{array}$ & Functionality & 1 \\
\hline & Bicycle Comfort & 1 & - Bicycle Comfort & Functionality & 1 \\
\hline & Pedestrian Comfort & 1 & - & - & 0 \\
\hline & Car Parking Capacity & 1 & - & - & 0 \\
\hline
\end{tabular}

Table 26 Sample Table for the Analysis by Weighted Criteria with DGNB 


\subsection{Discussion}

The analysis by groups of importance discloses weaknesses for all green building certification systems. All three systems cover less than $50 \%$ of the total number of points (Table 11). Thereby, BREEAM and DGNB achieved a higher result of ca. $6 \%-8 \%$ in comparison with LEED. By viewing each group of importance, BREEAM and DGNB also obtain a higher score than LEED in each individual group. BREEAM ranks first in the Important criteria group and DGNB received the best score in Very Important and Less Important criteria groups. However, the $50 \%$ coverage can also be seen as the upper limit. Analyzing the certification systems by criterion LEED's strengths lie in Materials, Land Use, and Ecology, Water, and Aspects during Construction. Major weaknesses (criteria groups with a score of 0) can be named with Building Adaptability, Safety and Security, Management and Maintenance, and Usability. BREEAM's strengths are Energy, Life Cycle Costs, Accessibility of the Building and Access to Transport, and Aspects during Construction. Areas for necessary improvement (criteria groups with a score of 0) are the topics Waste and Usability. DGNB shows a good performance in issues regarding Life Cycle Costs, Site Selection, and Process Quality. It needs further development in the subjects Waste, Aspects during Construction, Innovation, and Usability. All three certification systems have to extend their assessment systems with the Less Important criteria groups, since they are not or only rarely involved.

If we consider the areas Environment, Social \& Culture, Economic, Functional \& Technical and Process (Figure 24), LEED leads the area Environment; DGNB ranks first in Social \& Culture and Economic. In the latter LEED shows necessary improvements. All three systems ignore in this case the area Functional \& Technical. 
For the analysis, especially when considering the different areas, we have to consider that the composition of each area or group of importance was based on a table set up by the organization Sustainability Performance Assessment and Benchmarking of Buildings (2010). Therefore the figures $15-19$ in section 3.3 were presented not to mislead the reader since the three green building certification systems cover all 5 areas generally.

\begin{tabular}{|c|c|c|c|c|c|c|c|c|c|}
\hline $\begin{array}{c}\text { Group of } \\
\text { Importance }\end{array}$ & Criteria Group & \multicolumn{2}{|c|}{$\begin{array}{l}\text { Possible } \\
\text { Points }\end{array}$} & \multicolumn{2}{|c|}{$\begin{array}{l}\text { LEED } \\
\text { Score }\end{array}$} & \multicolumn{2}{|c|}{$\begin{array}{l}\text { BREEAM } \\
\text { Score }\end{array}$} & \multicolumn{2}{|c|}{$\begin{array}{l}\text { DGNB } \\
\text { Score }\end{array}$} \\
\hline \multirow{11}{*}{ 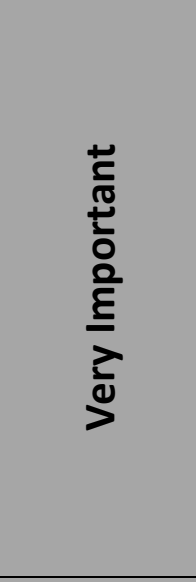 } & Energy & 6 & \multirow{11}{*}{83} & 3.5 & \multirow{11}{*}{34} & 4 & \multirow{11}{*}{38.5} & 3 & \multirow{11}{*}{39.5} \\
\hline & Materials & 4 & & 3 & & 2 & & 1 & \\
\hline & Climate Change & 8 & & 2.5 & & 2 & & 4 & \\
\hline & Land Use and Ecology & 6 & & 5 & & 4 & & 3 & \\
\hline & Water & 8 & & 5 & & 4 & & 2 & \\
\hline & Waste & 5 & & 1 & & 0 & & 0 & \\
\hline & Life Cycle Costs & 6 & & 1 & & 4.5 & & 5 & \\
\hline & Building Adaptability & 7 & & 0 & & 1 & & 3 & \\
\hline & Comfort and Health & 21 & & 10 & & 10 & & 11.5 & \\
\hline & $\begin{array}{l}\text { Accessibility of the Building and } \\
\text { Access to Transport }\end{array}$ & 5 & & 3 & & 4 & & 3 & \\
\hline & Safety and Security & 7 & & 0 & & 3 & & 4 & \\
\hline \multirow{6}{*}{ 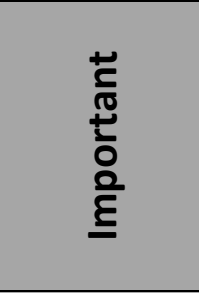 } & Site Selection & 2 & \multirow{6}{*}{8.5} & 1 & \multirow{6}{*}{3.5} & 1 & \multirow{6}{*}{4.75} & 1.5 & \multirow{6}{*}{4.5} \\
\hline & Aspects during Construction & 1 & & 1 & & 1 & & 0 & \\
\hline & Management and Maintenance & 2 & & 0 & & 0.75 & & 1 & \\
\hline & Process Quality & 2.5 & & 1 & & 1.5 & & 2 & \\
\hline & Innovation & 0.5 & & 0.5 & & 0.5 & & 0 & \\
\hline & Usability & 0.5 & & 0 & & 0 & & 0 & \\
\hline \multirow{5}{*}{ 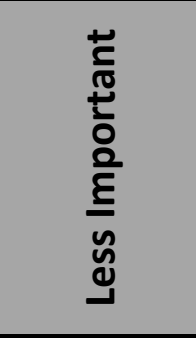 } & Further Environmental Criteria & 0.75 & \multirow{5}{*}{5} & 0 & \multirow{5}{*}{0.375} & 0 & \multirow{5}{*}{0.5} & 0 & \multirow{5}{*}{1.25} \\
\hline & $\begin{array}{l}\text { Further Indoor Environment } \\
\text { Criteria }\end{array}$ & 0.5 & & 0 & & 0 & & 0 & \\
\hline & $\begin{array}{l}\text { Architectural And Cultural } \\
\text { Considerations }\end{array}$ & 1.25 & & 0 & & 0 & & 0.75 & \\
\hline & Externalities & 1.75 & & 0.25 & & 0 & & 0 & \\
\hline & Planning \& Implementation & 0.75 & & 0.125 & & 0.5 & & 0.5 & \\
\hline \multicolumn{2}{|r|}{ Total } & \multicolumn{2}{|c|}{96.5} & \multicolumn{2}{|c|}{37.875} & \multicolumn{2}{|c|}{43.75} & \multicolumn{2}{|c|}{45.25} \\
\hline & Percentage & \multicolumn{2}{|c|}{$100 \%$} & \multicolumn{2}{|c|}{$39.25 \%$} & \multicolumn{2}{|c|}{$45.35 \%$} & \multicolumn{2}{|c|}{$46.90 \%$} \\
\hline
\end{tabular}

Table 27 Summary Table for Analysis of LEED, BREEAM, and DGNB by Weighted Criteria 


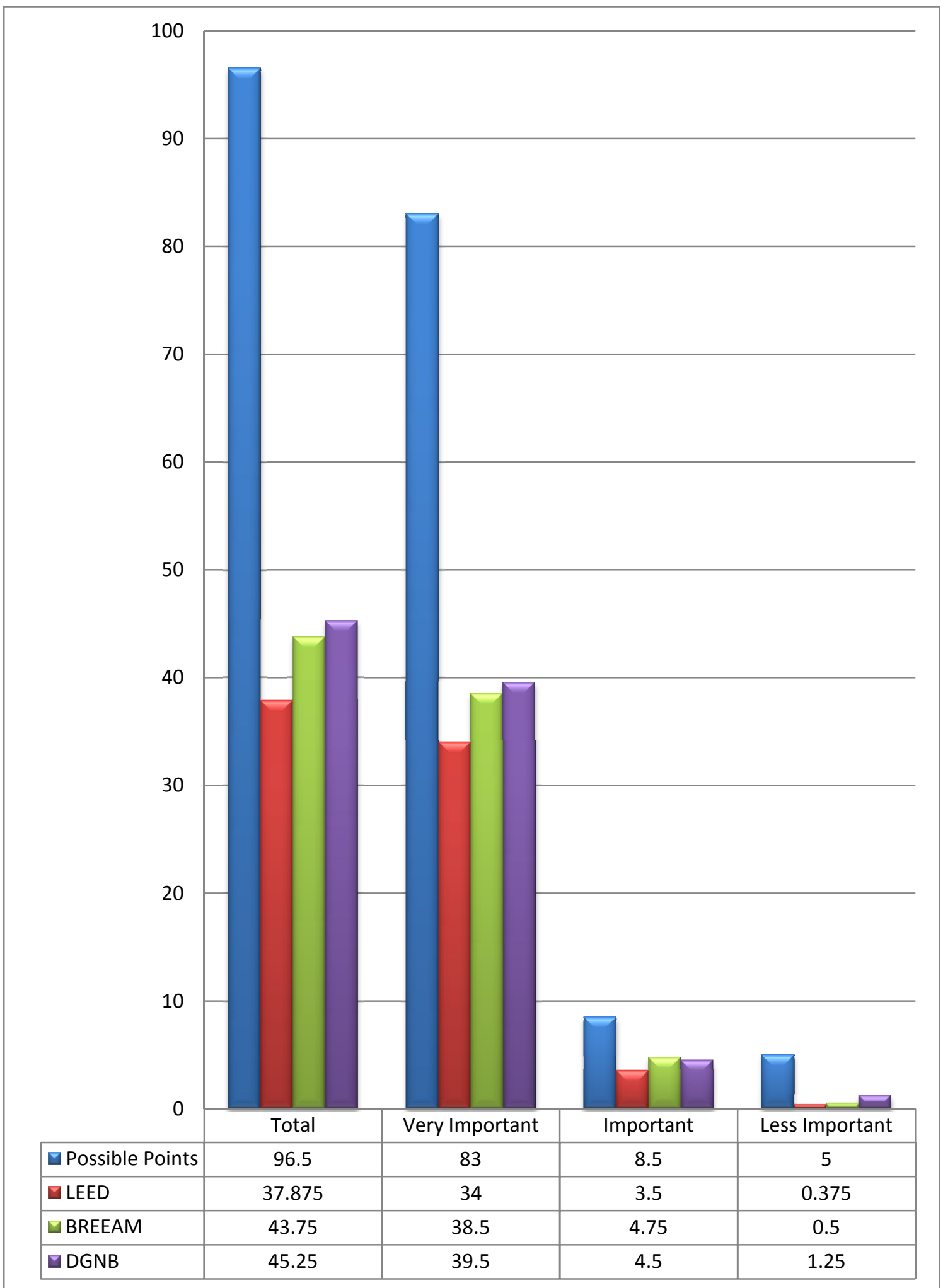

Figure 24 Comparison of LEED, BREEAM, and DGNB by Groups of Importance 


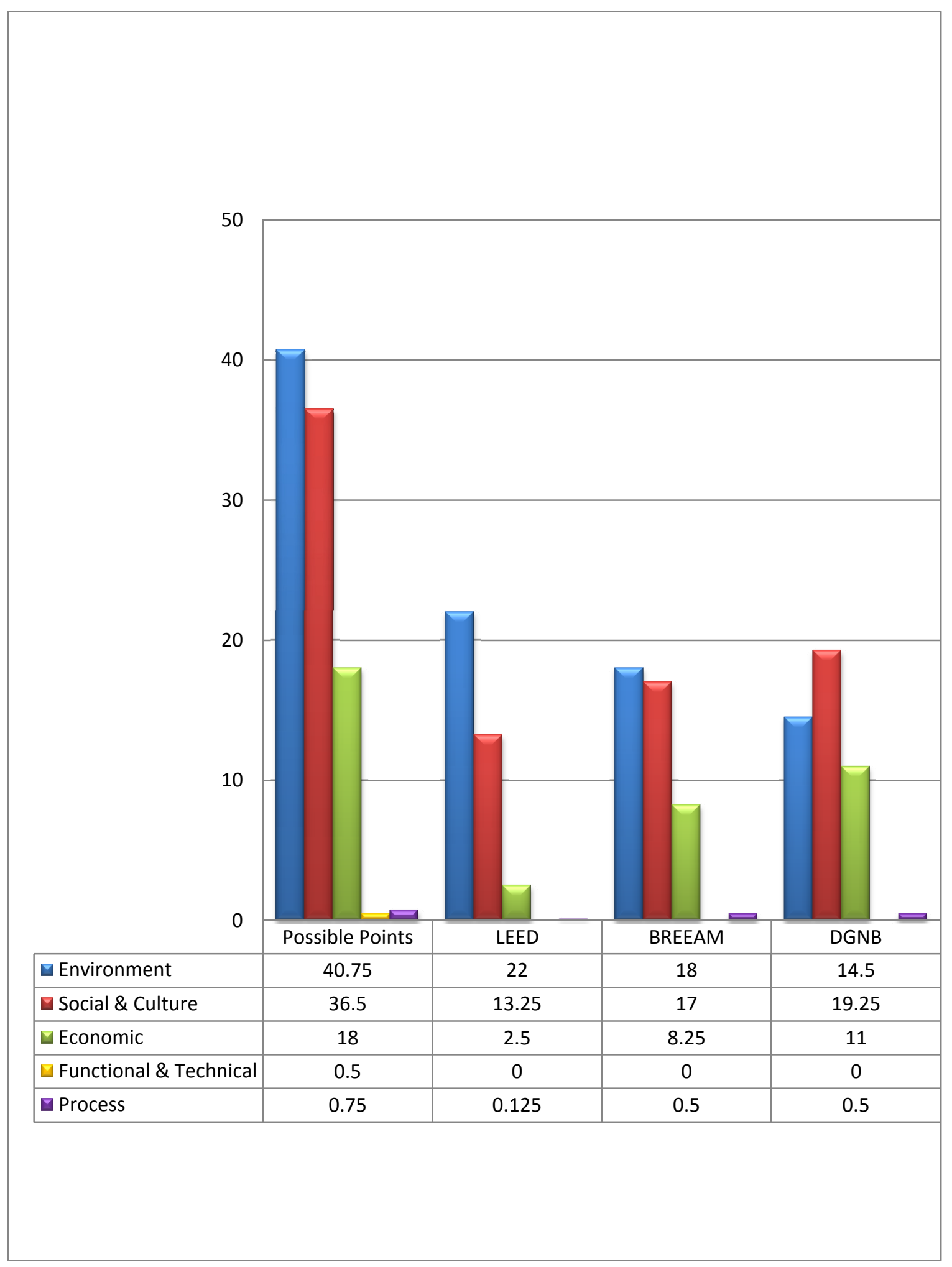

Figure 25 Comparison of LEED, BREEAM, and DGNB by Main Groups 


\section{Summary and Conclusion}

\subsection{Summary}

The surveys in the introduction indicated the willingness and readiness of stakeholders to build green since a property's entire life cycle already plays an increasingly important role in the industry. Other aspects of sustainability, such as adaptability for use by third parties or flexible design, increase the market potential strongly. Even more important is the fact that sustainable construction has a considerable impact on the sustainable actions of our society.

To measure these and other important aspects of sustainable construction, several providers came into the market and established certification systems, however, each with its own mix and combination of green building criteria. Therefore, a comparison of existing rating methods with the currently used criteria would not be reliable. In addition, the following questions arise: do current certification systems such as LEED, BREEAM or DGNB intrinsically consider any aspect of sustainability, and do they measure it to the same extent? The response must be based on a comprehensive set of sustainable indicators, developed by all stakeholders, from different regions with their own conditions and needs.

The literature review could present initial attempts by political and voluntary organizations, alliances between industry and academia, and individual and groups of researchers to solve this difficulty. The studies discussed green building certification criteria that have to be considered to accurately measure a building's sustainability, instead of using them merely for the "Mainstream". 
The literature review resulted in the collection of green building criteria. The collected long list was sorted in terms of Environment, Social \& Culture, Economic, Functional \& Technical, and Process. The following weighting by organization in categories of importance constituted the basis for the third analysis of the study.

The first analysis, the evaluation by a combination of the sections currently used by the three certification systems, indicated a resemblance of emphasis between LEED and BREEAM and their renunciation of certain sections. Contrary, DGNB emphasized other categories.

The second analysis assessed the certification systems with regard to their consideration of environmental criteria. LEED was indicated as the system that considers more environmental criteria than BREEAM or DGNB. However, all three systems cannot assert to sufficiently assess the environmental performance of a green building, since many criteria are not covered by each green building certification system.

The third analysis, the evaluation by groups of importance, as mentioned before, could identify which criteria are covered and which are not considered by each of the analyzed green building certification systems. The achieved coverage by all three systems was less than $50 \%$ of the total number of possible points. BREEAM and DGNB could reach a higher total score than LEED. By viewing each group of importance individually, BREEAM and DGNB also obtained more points than LEED. However, the 50\% coverage can also be seen as the upper limit in this case. LEED ranked first in the area Environment. In Social \& Culture and Economic, DGNB ranked first. Nevertheless, the analysis revealed that all three systems ignored the area Functional \& Technical. 


\subsection{Conclusion}

The study upholds the statements that current certification systems differ greatly since every system uses its own set of criteria. As a result, it is challenging to compare those systems. In addition, they cover aspects of sustainability only partially. Many criteria, such as Acoustic Comfort, are not included by LEED. In fact, entire groups of criteria (e.g., Economic) are not well investigated by LEED; a few criteria only mention that the impact of reducing the measured aspect will result in cost benefits. Similar weaknesses exist in the other two certification systems, BREEAM and DGNB, which are also not comprehensive.

Among others, the organization Sustainability Performance Assessment and Benchmarking of Buildings (2011), or the researchers Nannen (2011) and Dirlich (2011), characterized that a comprehensive and reliable green building certification has to measure a building's technical and process quality as well. The figures 15-19 in section 3.3 presented the gaps in terms of covering those criteria, especially by the first generation (LEED and BREEAM). DGNB, as representative of the second generation, meets this requirement; but on the other side, it has weaknesses in covering environmental indicators.

Furthermore, the study reveals that present certification systems ignore the society's demands regarding sustainability. The table, established by the organization Sustainability Performance Assessment and Benchmarking of Buildings (SuPerBuildings, 2010), summarized the most covered issues within the current building evaluation tools. This collection obviously discloses the tendency to focus on needs of building owners. 
However, building sustainability is an essential part to the overall sustainability of society, and therefore, it should be assessed in consideration of this fact.

Since the table, set up by SuPerBuildings (2010), was utilized for the first analysis, the significance of the study is limited to a certain degree. Another composition of the criteria may lead to other results. However, the figures 15-19 in section 3.3 and the third analysis in chapter 6 clearly underline the necessary further development of current green building certification systems.

It also cannot be denied that the study gives an own developed set of criteria, which could be reduced or extended. This difficulty has already been identified and different research projects have tried to resolve it. However, a final consensus has not been achieved; that constitutes the crucial problem all stakeholders have to solve in order to facilitate comparison between different green building certification systems.

The analysis clearly demonstrated the necessary further improvement of the three systems since important categories and/or criteria are missing or an appropriate attention has not been drawn to them. A few aspects for future considerations that could or in fact should be targeted:

- the standardization of a comprehensive set of criteria, and also of the metric measurement, by view of the society has to be directed. Those universal standards have to be applicable in any region with its own climate, social-cultural, legal and economic conditions which leads to a realistic inter building and inter countries comparison. For example, there are several methods to calculate the Common Carbon Metric; the building 
sustainability industry has to identify one common approach of measuring this concern.

- many building owners are reluctant towards green construction since there is a need for more data especially about non-financial benefits. Can social and environmental advantages be measured only with saved costs since a sustainable building leads to higher productivity? Or is there another unit that gives an additional and more worthwhile value for green construction?

- an idea for providing results could be the presentation of those results in a range of aggregated levels. Since stakeholders' preferred output format varies, a result at criteria level, subgroup level, main group level, and as main result level may be established. With this approach, a building could be stated, for example, as environmentally satisfying, but social-culturally or economically non-lucrative. 


\section{REFERENCES}

Alwaer, H., Clements-Crome, D.J. (2010), Key performance indicators (KPIs) and priority setting in using the multi-attribute approach for assessing sustainable intelligent buildings. Building and Environment 45, pp. 799-807.

Building Research Establishment (BRE) (2011), BRE Environmental Assessment Method (BREEAM). BRE Global Ltd, Watford, Great Britain.

Dirlich, S., (2011), A Comparison of Assessment and Certification Schemes for Sustainable Building and Suggestions for an International Standard System. The IMRE Journal Volume 5 (1), Freiberg, Germany.

Ebert, T., Eßig, N., and Hauser, G. (2011), Green building certification systems, Assessing sustainablity, International systems comparison, Economic impact of certifications. The Institute for International Documentation of Architecture, Munich, Germany.

Eißig, N. (2010), Sustainability of Olympic Buildings. Stuttgart, Germany, p.47.

Ernst \& Young Real Estate GmbH (2008), Green Building and the Sustainability of Real Estate are Important Themes for the Building Sector.

Ernst \& Young Real Estate GmbH (2008), Influence of Aspects of Sustainability on Decisions about Acquiring Real Estate.

European Union (2002), European Directive on the Energy Performance of Buildings.

Feifer, L., (2011), 786: Sustainability Indicators in Buildings - Identifying Key Performance Indicators, Denmark.

German Sustainable Building Council (DGNB) (2012), DGNB Certification System. DGNB GmbH, Stuttgart, Germany.

International Initiative for a Sustainable Built Environment (iiSBE) (2012), Overview of the SBTool assessment framework.

International Organization of Standardization (ISO) (2011), ISO/TS 21929-1 Sustainability in building construction - Sustainability indicators - Part 1: Framework for the development of indicators for buildings. ISO copyright office, Geneva, Switzerland. 
Japan Sustainable Building Consortium (JSBC) (2011), Comprehensive Assessment System for Built Environment Efficiency (CASBEE). Japan GreenBuild Council (JaGBC) / Japan Sustainable Building Consortium (JSBC).

Label for Environmental, Social and Economic Buildings (LEnSE) (2008). European Commission, Brussels, Belgium.

Liu, J., Ding, G. K.C., Samali, B. (2011), Quanitfying and assessing impacts of building processes in a 'triple bottom line approach'. World Sustainable Building Conference, Helsinki, Finland.

Nannen, C. (2011), Sustainable Education Buildings in Germany. World Sustainable Building Conference, Helsinki, Finland.

Nguyen, B. K., Altan, H. (2012), Tall-Building Projects Sustainability Indicator (TSPI): A New Design and Environmental Assessment Tool for Tall Buildings. Multidisciplinary Digital Publishing Institute, Basel, Switzerland, pp. 43-62.

OECD (2005), Environment at a glance: OECD environmental indicators. Organization for Economic Co-operation and Development, Paris, France.

OPEN HOUSE (2011), Core Indicators. World Sustainable Building Conference, Helsinki, Finland.

Perfection (2011), Key Performance Indicators for the Indoor Environment. World Sustainable Building Conference, Helsinki, Finland.

Poston, A., Emmanuel, R., Thomson, C. (2011), Developing whole life, holistic sustainability assessments. World Sustainable Building Conference, Helsinki, Finland.

Sustainability Performance Assessment and Benchmarking of Buildings (SuPerBuildings) (2010), Conclusions about the need for development of sustainability indicators and assessment methods. SuPerBuildings Project Deliverable 2.1.

Sustainability Performance Assessment and Benchmarking of Buildings (SuPerBuildings) (2011), Objectives of the project, overview of the work packages, selection / development of indicators. World Sustainable Building Conference, Helsinki, Finland.

Sustainable Building Alliance (SB Alliance) (2009), Core set of indicators, Paris. 
United Nations Department of Economic and Social Affairs (2007), Indicator of Sustainable Development: Guideline and Methodologies. United Nations publication, New York.

U.S. Green Building Council (USGBC) (2011), Leadership in Energy and Environmental Design (LEED). U.S. Green Building Council, Inc., Washington DC. 


\section{LEED:}

\begin{tabular}{|c|c|c|}
\hline Category & Criterion & $\begin{array}{c}\text { Average } \\
\text { Percentage } \\
\text { Contribution to } \\
\text { Overall Score }\end{array}$ \\
\hline \multirow{20}{*}{ 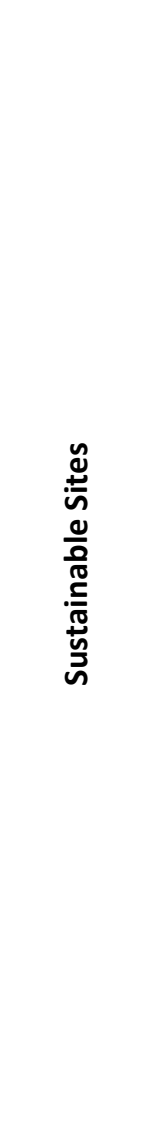 } & Construction Activity Pollution Prevention & \multirow{20}{*}{$\begin{array}{c}21.35 \% \\
(16.40 \%- \\
23.60 \%)\end{array}$} \\
\hline & Environmental Site Assessment & \\
\hline & Site Selection & \\
\hline & Development Density and Community Connectivity & \\
\hline & Brownfield Redevelopment & \\
\hline & Alternative Transportation - Public Transportation Access & \\
\hline & Alternative Transportation - Bicycle Storage and Changing Rooms & \\
\hline & Alternative Transportation - Low-Emitting and Fuel-Efficient Vehicles & \\
\hline & Alternative Transportation - Parking Capacity & \\
\hline & Site Development - Protect or Restore Habitat & \\
\hline & Site Development - Maximize Open Space & \\
\hline & Stormwater Design - Quantity Control & \\
\hline & Stormwater Design - Quality Control & \\
\hline & Heat Island Effect - Non-roof & \\
\hline & Heat Island Effect - Roof & \\
\hline & Light Pollution Reduction & \\
\hline & Site Master Plan & \\
\hline & Joint Use of Facilities & \\
\hline & Connection to the Natural World - Places of Respite & \\
\hline & Connection to the Natural World-Direct Exterior Access for Patients & \\
\hline
\end{tabular}

\begin{tabular}{|c|c|c|}
\hline Category & Criterion & $\begin{array}{c}\text { Average } \\
\text { Percentage } \\
\text { Contribution to } \\
\text { Overall Score }\end{array}$ \\
\hline \multirow{6}{*}{ 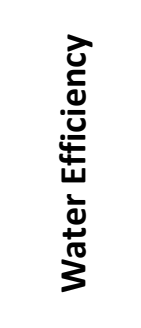 } & Water Use Reduction - 20\% Reduction & \multirow{6}{*}{$\begin{array}{c}9.1 \% \\
(8.20 \%- \\
10.00 \%)\end{array}$} \\
\hline & Minimize Potable Water Use for Medical Equipment Cooling & \\
\hline & Water Efficient Landscaping & \\
\hline & Innovative Waste Water Technologies & \\
\hline & Water Use Reduction & \\
\hline & Process Water Use Reduction & \\
\hline
\end{tabular}




\begin{tabular}{|c|c|c|}
\hline Category & Criterion & $\begin{array}{c}\text { Average } \\
\text { Percentage } \\
\text { Contribution to } \\
\text { Overall Score }\end{array}$ \\
\hline \multirow{10}{*}{ 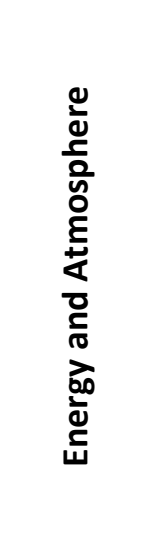 } & Fundamental Commissioning of Building Energy Systems & \multirow{10}{*}{$\begin{array}{c}12.93 \% \\
(11.80 \%- \\
14.50 \%)\end{array}$} \\
\hline & Minimum Energy Performance & \\
\hline & Fundamental Refrigerant Management & \\
\hline & Optimize Energy Performance & \\
\hline & On-Site Renewable Energy & \\
\hline & Enhanced Commissioning & \\
\hline & Enhanced Refrigerant Management & \\
\hline & Measurement and Verification & \\
\hline & Green Power & \\
\hline & Community Contaminant Prevention-Airborne Releases & \\
\hline
\end{tabular}

\begin{tabular}{|c|c|c|}
\hline Category & Criterion & $\begin{array}{c}\text { Average } \\
\text { Percentage } \\
\text { Contribution to } \\
\text { Overall Score }\end{array}$ \\
\hline \multirow{15}{*}{ 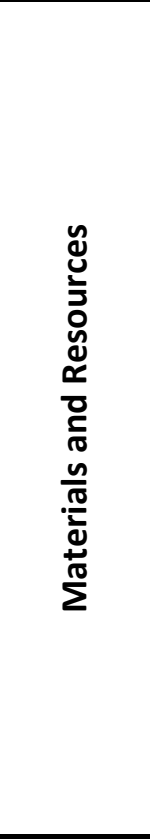 } & Storage and Collection of Recyclables & \multirow{15}{*}{$\begin{array}{c}12.93 \% \\
(11.80 \%- \\
14.50 \%)\end{array}$} \\
\hline & Community Contaminant Prevention-Airborne Releases & \\
\hline & Building Reuse - Maintaining Existing Walls, Floors, and Roof & \\
\hline & Building Reuse - Maintain $50 \%$ of Interior Non-Structural Elements & \\
\hline & Construction Waste Management & \\
\hline & Material Reuse & \\
\hline & Recycled Content & \\
\hline & Regional Materials & \\
\hline & Rapidly Renewable Materials & \\
\hline & Certified Wood & \\
\hline & Sustainably Sourced Materials and Products & \\
\hline & PBT Source Reduction-Mercury in Lamps & \\
\hline & PBT Source Reduction-Lead, Cadmium, and Copper & \\
\hline & Furniture and Medical Furnishings & \\
\hline & Resource Use-Design for Flexibility & \\
\hline
\end{tabular}




\begin{tabular}{|c|c|c|}
\hline Category & Criterion & $\begin{array}{c}\text { Average } \\
\text { Percentage } \\
\text { Contribution to } \\
\text { Overall Score }\end{array}$ \\
\hline \multirow{22}{*}{ 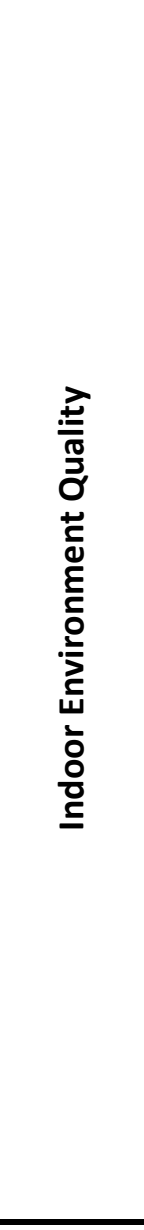 } & Minimum Indoor Air Quality Performance & \multirow{22}{*}{$\begin{array}{c}15.23 \% \\
(13.60 \%- \\
17.30 \%)\end{array}$} \\
\hline & Environmental Tobacco Smoke (ETS) Control & \\
\hline & Minimum Acoustical Performance & \\
\hline & Hazardous Material Removal or Encapsulation & \\
\hline & Outdoor Air Delivery Monitoring & \\
\hline & Acoustic Environment & \\
\hline & Increased Ventilation & \\
\hline & Construction IAQ Management Plan - During Construction & \\
\hline & Construction IAQ Management Plan - Before Occupancy & \\
\hline & Low-Emitting Materials - Adhesives and Sealants & \\
\hline & Low-Emitting Materials - Paints and Coatings & \\
\hline & Low-Emitting Materials - Flooring Systems & \\
\hline & Low-Emitting Materials - Composite Wood and Agrifiber Products & \\
\hline & Indoor Chemical and Pollutant Source Control & \\
\hline & Controllability of Systems - Lighting & \\
\hline & Controllability of Systems - Thermal Comfort & \\
\hline & Thermal Comfort - Design & \\
\hline & Thermal Comfort - Verification & \\
\hline & Daylight and Views - Daylight & \\
\hline & Daylight and Views - Views & \\
\hline & Enhanced Acoustical Performance & \\
\hline & Mold Prevention & \\
\hline
\end{tabular}




\begin{tabular}{|c|c|c|}
\hline Category & Criterion & $\begin{array}{c}\text { Average } \\
\text { Percentage } \\
\text { Contribution to } \\
\text { Overall Score }\end{array}$ \\
\hline \multirow{9}{*}{ 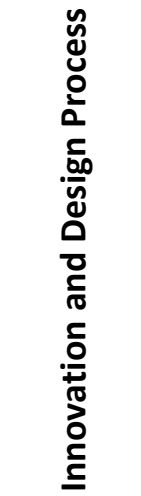 } & Integrated Project Planning and Design & \multirow{9}{*}{$5.50 \%$} \\
\hline & Innovation in Design: Specific Title & \\
\hline & Innovation in Design: Specific Title & \\
\hline & Innovation in Design: Specific Title & \\
\hline & Innovation in Design: Specific Title & \\
\hline & Innovation in Design: Specific Title & \\
\hline & LEED Accredited Professional & \\
\hline & The School as a Teaching Tool & \\
\hline & Integrated Project Planning and Design & \\
\hline
\end{tabular}

\begin{tabular}{|c|c|c|}
\hline Category & Criterion & $\begin{array}{c}\text { Average } \\
\text { Percentage } \\
\text { Contribution to } \\
\text { Overall Score }\end{array}$ \\
\hline \multirow{4}{*}{ 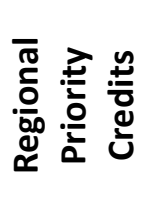 } & Regional Priority: Specific Credits & \multirow{4}{*}{$3.60 \%$} \\
\hline & Regional Priority: Specific Credits & \\
\hline & Regional Priority: Specific Credits & \\
\hline & Regional Priority: Specific Credits & \\
\hline
\end{tabular}

\begin{tabular}{|c|c|c|}
\hline Category & Criterion & $\begin{array}{c}\text { Average } \\
\text { Percentage } \\
\text { Contribution to } \\
\text { Overall Score }\end{array}$ \\
\hline 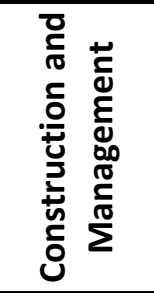 & Considered partially in individual criteria & $0.00 \%$ \\
\hline
\end{tabular}




\begin{tabular}{|c|c|c|}
\hline Category & Criterion & $\begin{array}{c}\text { Average } \\
\text { Percentage } \\
\text { Contribution to } \\
\text { Overall Score }\end{array}$ \\
\hline 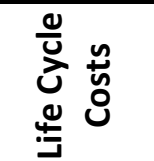 & Considered partially in individual criteria & $0.00 \%$ \\
\hline
\end{tabular}

\begin{tabular}{|c|c|c|}
\hline Category & Criterion & $\begin{array}{c}\text { Average } \\
\text { Percentage } \\
\text { Contribution to } \\
\text { Overall Score }\end{array}$ \\
\hline 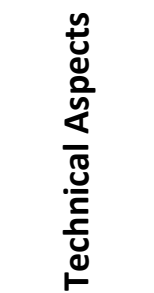 & - & $0.00 \%$ \\
\hline
\end{tabular}


BREEAM:

\begin{tabular}{|c|c|c|c|}
\hline Category & $\begin{array}{c}\text { Categories } \\
\text { BREEAM }\end{array}$ & Criterion & $\begin{array}{c}\text { Average } \\
\text { Percentage } \\
\text { Contribution to } \\
\text { Overall Score }\end{array}$ \\
\hline \multirow{10}{*}{ 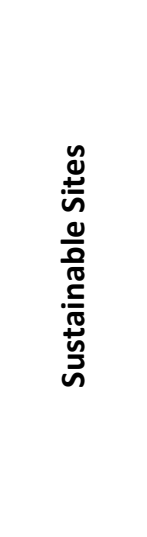 } & \multirow{5}{*}{ 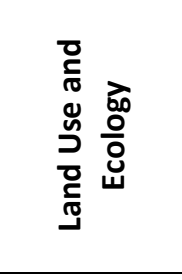 } & Site Selection & \multirow{10}{*}{$\begin{array}{c}18.02 \% \\
(17.90 \%- \\
18.10 \%)\end{array}$} \\
\hline & & Ecological Value of Site and Protection of Ecological Features & \\
\hline & & Mitigating Ecological Impact & \\
\hline & & Enhancing Site Ecology & \\
\hline & & Long Term Impact on Biodiversity & \\
\hline & \multirow{5}{*}{ 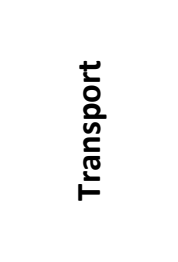 } & Public Transport Accessibility & \\
\hline & & Proximity to Amenities & \\
\hline & & Cyclist Facilities & \\
\hline & & Maximum Car Parking Capacity & \\
\hline & & Travel Plan & \\
\hline
\end{tabular}

\begin{tabular}{|c|c|c|c|}
\hline Category & $\begin{array}{l}\text { Category } \\
\text { BREEAM }\end{array}$ & Criterion & $\begin{array}{c}\text { Average } \\
\text { Percentage } \\
\text { Contribution to } \\
\text { Overall Score }\end{array}$ \\
\hline \multirow{4}{*}{ 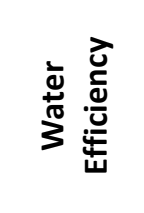 } & \multirow{4}{*}{$\begin{array}{l}\frac{ \pm}{\pi} \\
\frac{\pi}{3}\end{array}$} & Water Consumption & \multirow{4}{*}{$6.00 \%$} \\
\hline & & Water Monitoring & \\
\hline & & Water Leak Detection and Prevention & \\
\hline & & Water Efficient Equipment & \\
\hline
\end{tabular}




\begin{tabular}{|c|c|c|c|}
\hline Category & $\begin{array}{c}\text { Categories } \\
\text { BREEAM }\end{array}$ & Criterion & $\begin{array}{c}\text { Average } \\
\text { Percentage } \\
\text { Contribution to } \\
\text { Overall Score }\end{array}$ \\
\hline \multirow{14}{*}{ 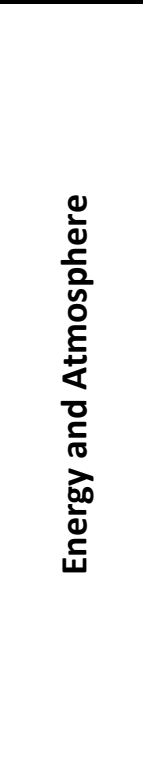 } & \multirow{9}{*}{ 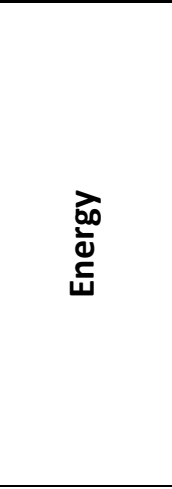 } & Reduction of $\mathrm{CO} 2$ Emissions & \multirow{14}{*}{$\begin{array}{c}28.99 \% \\
(28.90 \%- \\
29.10 \%)\end{array}$} \\
\hline & & Energy Monitoring & \\
\hline & & External Lighting & \\
\hline & & Low and Zero Carbon Technologies & \\
\hline & & Energy Efficient Cold Storage & \\
\hline & & Energy Efficient Transportation System & \\
\hline & & Energy Efficient Laboratory Systems & \\
\hline & & Energy Efficient Equipment & \\
\hline & & Drying Space & \\
\hline & \multirow{5}{*}{ 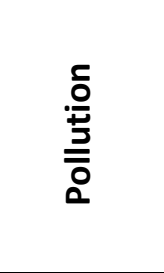 } & Impact of Refrigerants & \\
\hline & & NOx Emissions & \\
\hline & & Surface Water Runoff & \\
\hline & & Reduction of Night Time Light Pollution & \\
\hline & & Noise Attenuation & \\
\hline
\end{tabular}

\begin{tabular}{|c|c|c|c|}
\hline Category & $\begin{array}{l}\text { Categories } \\
\text { BREEAM }\end{array}$ & Criterion & $\begin{array}{c}\text { Average } \\
\text { Percentage } \\
\text { Contribution } \\
\text { to Overall } \\
\text { Score } \\
\end{array}$ \\
\hline \multirow{9}{*}{ 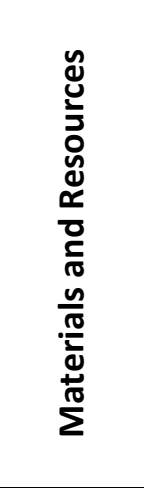 } & \multirow{5}{*}{$\begin{array}{l}\frac{\omega}{\pi} \\
\frac{\pi}{2} \\
\frac{\pi}{\pi} \\
\sum\end{array}$} & Life Cycle Impacts & \multirow{9}{*}{$20.15 \%$} \\
\hline & & Hard Landscaping and Boundary Protection & \\
\hline & & Responsible Sourcing of Materials & \\
\hline & & Insulation & \\
\hline & & Designing for Robustness & \\
\hline & \multirow{4}{*}{\begin{tabular}{l}
$\stackrel{0}{5}$ \\
\multirow{n}{\pi}{} \\
3
\end{tabular}} & Construction Waste Management & \\
\hline & & Recycled Aggregates & \\
\hline & & Operational Waste & \\
\hline & & Speculative Floor and Ceiling Finishes & \\
\hline
\end{tabular}




\begin{tabular}{|c|c|c|c|}
\hline Category & $\begin{array}{l}\text { Category } \\
\text { BREEAM }\end{array}$ & Criterion & $\begin{array}{c}\text { Average } \\
\text { Percentage } \\
\text { Contribution } \\
\text { to Overall } \\
\text { Score }\end{array}$ \\
\hline \multirow{6}{*}{ 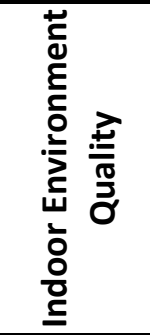 } & \multirow{6}{*}{ 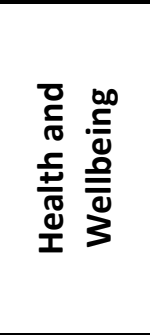 } & Visual Comfort & \multirow{6}{*}{$15.00 \%$} \\
\hline & & Indoor Air Quality & \\
\hline & & Thermal Comfort & \\
\hline & & Water Quality & \\
\hline & & Acoustic Performance & \\
\hline & & Safety and Security & \\
\hline
\end{tabular}

\begin{tabular}{|c|c|c|c|}
\hline Category & $\begin{array}{l}\text { Category } \\
\text { BREEAM }\end{array}$ & Criterion & $\begin{array}{c}\text { Average } \\
\text { Percentage } \\
\text { Contribution } \\
\text { to Overall } \\
\text { Score }\end{array}$ \\
\hline 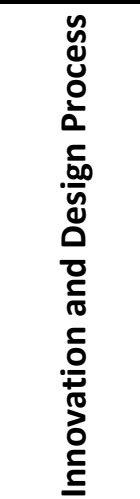 & 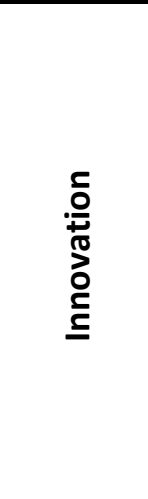 & Innovation & $10.00 \%$ \\
\hline
\end{tabular}

\begin{tabular}{|c|c|c|c|}
\hline Category & $\begin{array}{l}\text { Category } \\
\text { BREEAM }\end{array}$ & Criterion & $\begin{array}{c}\text { Average } \\
\text { Percentage } \\
\text { Contribution } \\
\text { to Overall } \\
\text { Score }\end{array}$ \\
\hline 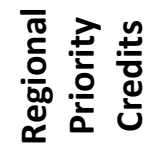 & - & - & $0.00 \%$ \\
\hline
\end{tabular}




\begin{tabular}{|c|c|c|c|}
\hline Category & $\begin{array}{l}\text { Category } \\
\text { BREEAM }\end{array}$ & Criterion & $\begin{array}{c}\text { Average } \\
\text { Percentage } \\
\text { Contribution } \\
\text { to Overall } \\
\text { Score }\end{array}$ \\
\hline \multirow{5}{*}{ 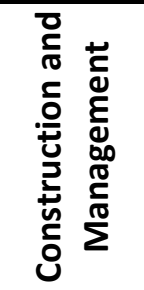 } & \multirow{5}{*}{ 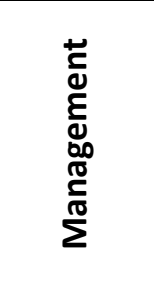 } & Sustainable Procurement & \multirow{5}{*}{$12.00 \%$} \\
\hline & & Responsible Construction Practices & \\
\hline & & Construction Site Impacts & \\
\hline & & Stakeholder Participation & \\
\hline & & Life Cycle Cost and Service Life Planning & \\
\hline
\end{tabular}

\begin{tabular}{|c|c|c|c|}
\hline Category & $\begin{array}{l}\text { Category } \\
\text { BREEAM }\end{array}$ & Criterion & $\begin{array}{c}\text { Average } \\
\text { Percentage } \\
\text { Contribution } \\
\text { to Overall } \\
\text { Score }\end{array}$ \\
\hline 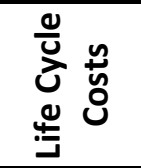 & - & Considered partially in "Management" & $0.00 \%$ \\
\hline
\end{tabular}

\begin{tabular}{|c|c|c|c|}
\hline Category & $\begin{array}{l}\text { Category } \\
\text { BREEAM }\end{array}$ & Criterion & $\begin{array}{c}\text { Average } \\
\text { Percentage } \\
\text { Contribution } \\
\text { to Overall } \\
\text { Score } \\
\end{array}$ \\
\hline 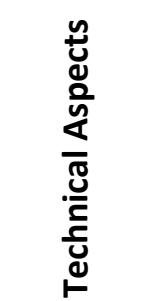 & - & Considered partially in individual criteria & $0.00 \%$ \\
\hline
\end{tabular}


DGNB:

\begin{tabular}{|c|c|c|c|}
\hline Category & $\begin{array}{l}\text { Categories } \\
\text { DGNB }\end{array}$ & Criterion & $\begin{array}{c}\text { Average } \\
\text { Percentage } \\
\text { Contribution } \\
\text { to Overall } \\
\text { Score }\end{array}$ \\
\hline \multirow{7}{*}{ 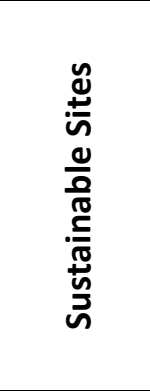 } & \multirow{4}{*}{ 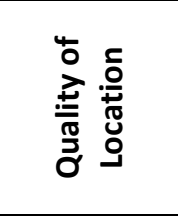 } & Micro Environment & \multirow{7}{*}{$\begin{array}{c}4.13 \% \\
(3.20 \%- \\
4.30 \%)\end{array}$} \\
\hline & & Image and Conditions of Site and Neighborhood & \\
\hline & & Transport Accessibility & \\
\hline & & Proximity to Amenities & \\
\hline & \multirow{3}{*}{ 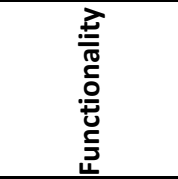 } & Barrier-Free Accessibility & \\
\hline & & Public Accessibility & \\
\hline & & Bicycle Comfort & \\
\hline
\end{tabular}

\begin{tabular}{|c|c|c|c|}
\hline Category & $\begin{array}{c}\text { Category } \\
\text { DGNB }\end{array}$ & Criterion & $\begin{array}{c}\text { Average } \\
\text { Percentage } \\
\text { Contribution } \\
\text { to Overall } \\
\text { Score }\end{array}$ \\
\hline 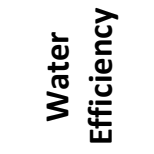 & - & Considered partially in "Resources and Waste" & $0.00 \%$ \\
\hline
\end{tabular}

\begin{tabular}{|c|c|c|c|}
\hline Category & $\begin{array}{l}\text { Category } \\
\text { DGNB }\end{array}$ & Criterion & $\begin{array}{c}\text { Average } \\
\text { Percentage } \\
\text { Contribution } \\
\text { to Overall } \\
\text { Score } \\
\end{array}$ \\
\hline \multirow{3}{*}{ 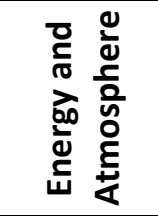 } & \multirow{3}{*}{ 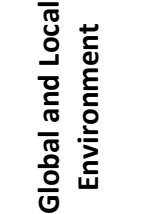 } & $\begin{array}{l}\text { Life Cycle Assessment of Emission Caused Environmental } \\
\text { Impacts }\end{array}$ & \multirow{3}{*}{$\begin{array}{c}12.03 \% \\
(11.30 \%- \\
12.40 \%)\end{array}$} \\
\hline & & Risks for Local Environment & \\
\hline & & Sustainable Material Extraction & \\
\hline
\end{tabular}




\begin{tabular}{|c|c|c|c|}
\hline Category & $\begin{array}{l}\text { Category } \\
\text { DGNB }\end{array}$ & Criterion & $\begin{array}{c}\text { Average } \\
\text { Percentage } \\
\text { Contribution } \\
\text { to Overall } \\
\text { Score }\end{array}$ \\
\hline \multirow{3}{*}{ 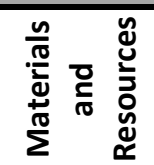 } & \multirow{3}{*}{ 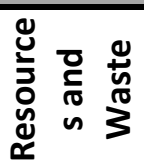 } & Life Cycle Assessment of Primary Energy & \multirow{3}{*}{$10.53 \%$} \\
\hline & & Demand of Drinking Water and Volume of Waste Water & \\
\hline & & Land Use & \\
\hline
\end{tabular}

\begin{tabular}{|c|c|c|c|}
\hline Category & $\begin{array}{c}\text { Category } \\
\text { DGNB }\end{array}$ & Criterion & $\begin{array}{c}\text { Average } \\
\text { Percentage } \\
\text { Contribution } \\
\text { to Overall } \\
\text { Score } \\
\end{array}$ \\
\hline \multirow{7}{*}{ 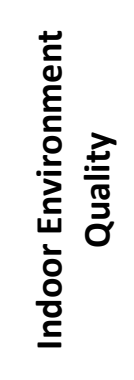 } & \multirow{7}{*}{ 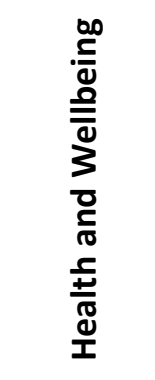 } & Thermal Comfort & \multirow{7}{*}{$\begin{array}{c}13.8 \% \\
(12.80 \%- \\
14.30 \%)\end{array}$} \\
\hline & & Indoor Air Quality & \\
\hline & & Acoustic Comfort & \\
\hline & & Visual Comfort & \\
\hline & & Influence of User & \\
\hline & & Roof Design & \\
\hline & & Safety and Risk of Incidents & \\
\hline
\end{tabular}

\begin{tabular}{|c|c|c|c|}
\hline Category & $\begin{array}{l}\text { Categories } \\
\text { DGNB }\end{array}$ & Criterion & $\begin{array}{c}\text { Average } \\
\text { Percentage } \\
\text { Contribution } \\
\text { to Overall } \\
\text { Score }\end{array}$ \\
\hline \multirow{8}{*}{ 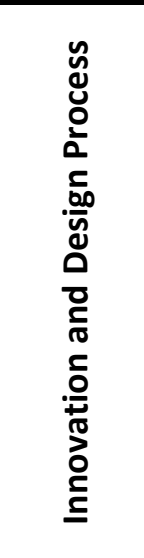 } & \multirow{3}{*}{ 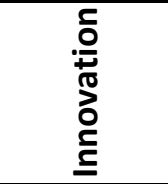 } & Method of Urban and Design Development Concept & \multirow{8}{*}{$\begin{array}{l}10.67 \% \\
(9.80 \%- \\
12.60 \%)\end{array}$} \\
\hline & & Artistic Aspects in Construction & \\
\hline & & Quality of Floor Plan & \\
\hline & \multirow{5}{*}{ 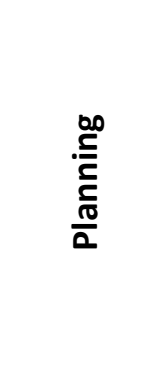 } & Quality Of Project Preparation & \\
\hline & & Integral Planning & \\
\hline & & Optimization and Complexity of Planning Method & \\
\hline & & $\begin{array}{l}\text { Evidence Of Sustainability During Bid Invitation And } \\
\text { Awarding }\end{array}$ & \\
\hline & & $\begin{array}{l}\text { Creation of Conditions for Optimal Use and } \\
\text { Management }\end{array}$ & \\
\hline
\end{tabular}




\begin{tabular}{|c|c|c|c|}
\hline Category & $\begin{array}{c}\text { Category } \\
\text { DGNB }\end{array}$ & Criterion & $\begin{array}{c}\text { Average } \\
\text { Percentage } \\
\text { Contribution } \\
\text { to Overall } \\
\text { Score }\end{array}$ \\
\hline 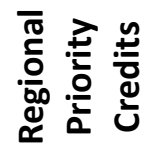 & - & - & $0.00 \%$ \\
\hline
\end{tabular}

\begin{tabular}{|c|c|c|c|}
\hline Category & $\begin{array}{c}\text { Category } \\
\text { DGNB }\end{array}$ & Criterion & $\begin{array}{c}\text { Average } \\
\text { Percentage } \\
\text { Contribution } \\
\text { to Overall } \\
\text { Score } \\
\end{array}$ \\
\hline \multirow{3}{*}{ 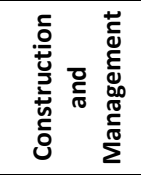 } & \multirow{3}{*}{ 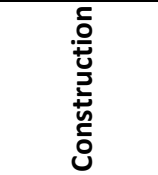 } & Construction Site / Construction Process & \multirow{3}{*}{$3.80 \%$} \\
\hline & & Quality Assurance for Construction & \\
\hline & & Systematic Commissioning & \\
\hline
\end{tabular}

\begin{tabular}{|c|c|c|c|}
\hline Category & $\begin{array}{c}\text { Category } \\
\text { DGNB }\end{array}$ & Criterion & $\begin{array}{c}\text { Average } \\
\text { Percentage } \\
\text { Contribution } \\
\text { to Overall } \\
\text { Score } \\
\end{array}$ \\
\hline \multirow{3}{*}{ 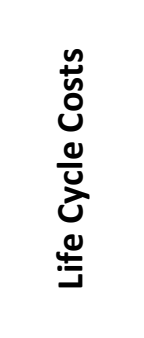 } & 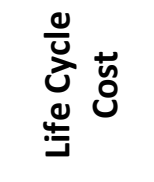 & Building-Related Life-Cycle Costs & \multirow{3}{*}{$\begin{array}{c}22.53 \% \\
(22.40 \%- \\
22.60 \%)\end{array}$} \\
\hline & \multirow{2}{*}{ 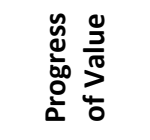 } & Flexibility and Convertibility & \\
\hline & & Marketability & \\
\hline
\end{tabular}




\begin{tabular}{|c|c|c|c|}
\hline Category & $\begin{array}{l}\text { Category } \\
\text { DGNB }\end{array}$ & Criterion & $\begin{array}{c}\text { Average } \\
\text { Percentage } \\
\text { Contribution } \\
\text { to Overall } \\
\text { Score }\end{array}$ \\
\hline \multirow{7}{*}{ 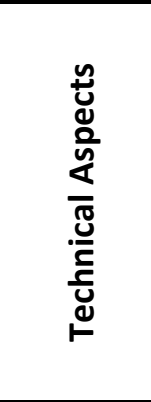 } & \multirow{7}{*}{ 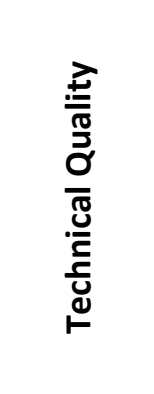 } & Fire Prevention & \multirow{7}{*}{$\begin{array}{c}22.52 \% \\
(22.40 \%- \\
22.70 \%)\end{array}$} \\
\hline & & Sound Insulation & \\
\hline & & $\begin{array}{l}\text { Quality of the Building Envelope With Regard to Heat } \\
\text { and Humidity }\end{array}$ & \\
\hline & & Adaptability of Technical Systems & \\
\hline & & Ease of Cleaning and Maintenance & \\
\hline & & Ease of Dismantling and Disassembly & \\
\hline & & Emission Control & \\
\hline
\end{tabular}




\section{APPENDIX B}

\section{LEED:}

\begin{tabular}{|c|c|c|c|c|c|}
\hline $\begin{array}{l}\text { Criteria } \\
\text { Group }\end{array}$ & Criteria & $\begin{array}{c}\text { Possible } \\
\text { Points }\end{array}$ & Title Criterion & $\begin{array}{l}\text { In Category } \\
\text { Included }\end{array}$ & Score \\
\hline \multirow{6}{*}{ ש } & $\begin{array}{l}\text { Site Location, Site } \\
\text { Characteristics }\end{array}$ & 1 & $\begin{array}{l}\text { - Site Selection } \\
\text { - Site Development } \\
\text { - Maximize Open } \\
\text { Space }\end{array}$ & $\begin{array}{l}\text { Sustainable } \\
\text { Sites }\end{array}$ & 1 \\
\hline & Infrastructure & 1 & $\begin{array}{l}\text { - Development } \\
\text { Density and } \\
\text { Community } \\
\text { Connectivity }\end{array}$ & $\begin{array}{c}\text { Sustainable } \\
\text { Sites }\end{array}$ & 1 \\
\hline & Neighboring Buildings & 1 & - & - & 0 \\
\hline & Heat Island Effect & 1 & $\begin{array}{l}\text { - Heat Island Effect } \\
\text { - Nonroof } \\
\text { - Heat Island Effect } \\
\text { - Roof }\end{array}$ & $\begin{array}{l}\text { Sustainable } \\
\text { Sites }\end{array}$ & 1 \\
\hline & Landscape Inputs & 1 & - & - & 0 \\
\hline & Risk At The Site & 1 & - & - & 0 \\
\hline
\end{tabular}

\begin{tabular}{|c|c|c|c|c|c|}
\hline $\begin{array}{l}\text { Criteria } \\
\text { Group }\end{array}$ & Criteria & $\begin{array}{l}\text { Possible } \\
\text { Points }\end{array}$ & Title Criterion & $\begin{array}{l}\text { In Category } \\
\text { Included }\end{array}$ & Score \\
\hline \multirow{4}{*}{$\frac{\dot{0}}{m} \frac{\frac{5}{n}}{\frac{1}{0}}$} & Site Ecology & 1 & - & - & 0 \\
\hline & Eutrophication & 1 & - & - & 0 \\
\hline & $\begin{array}{l}\text { Habitat Management } \\
\text { Plan }\end{array}$ & 1 & \multirow{2}{*}{$\begin{array}{l}\text { - Site Development } \\
\text { - Protect or } \\
\text { Restore Habitat }\end{array}$} & \multirow{2}{*}{$\begin{array}{l}\text { Sustainable } \\
\text { Sites }\end{array}$} & 1 \\
\hline & Biodiversity & 1 & & & 1 \\
\hline
\end{tabular}

\begin{tabular}{|c|c|c|c|c|c|}
\hline $\begin{array}{l}\text { Criteria } \\
\text { Group }\end{array}$ & Criteria & $\begin{array}{l}\text { Possible } \\
\text { Points }\end{array}$ & Title Criterion & $\begin{array}{l}\text { In Category } \\
\text { Included }\end{array}$ & Score \\
\hline \multirow{2}{*}{ (1) } & Green Field / Brown Field & 1 & $\begin{array}{l}\text { - Brownfield } \\
\text { Development }\end{array}$ & $\begin{array}{l}\text { Sustainable } \\
\text { Sites }\end{array}$ & 1 \\
\hline & $\begin{array}{l}\text { Land Regeneration \& } \\
\text { Development }\end{array}$ & 1 & $\begin{array}{l}\text { - Alternative } \\
\text { Transportation - } \\
\text { Low-Emitting and } \\
\text { Fuel-Efficient } \\
\text { Vehicles } \\
\text { - Alternative } \\
\text { Transportation - } \\
\text { Parking Capacity }\end{array}$ & $\begin{array}{l}\text { Sustainable } \\
\text { Sites }\end{array}$ & 1 \\
\hline
\end{tabular}




\begin{tabular}{|c|c|c|c|c|c|}
\hline $\begin{array}{l}\text { Criteria } \\
\text { Group }\end{array}$ & Criteria & $\begin{array}{l}\text { Possible } \\
\text { Points }\end{array}$ & Title Criterion & $\begin{array}{l}\text { In Category } \\
\text { Included }\end{array}$ & Score \\
\hline 4 & $\begin{array}{l}\text { Total Energy } \\
\text { Consumption }\end{array}$ & 1 & $\begin{array}{l}\text { - Minimum Energy } \\
\text { Performance } \\
\text { - Optimize Energy } \\
\text { Performance } \\
\text { Measurement and } \\
\text { Verification }\end{array}$ & $\begin{array}{l}\text { Energy and } \\
\text { Atmosphere }\end{array}$ & 1 \\
\hline & $\begin{array}{l}\text { Use Of Non-Renewable } \\
\text { Primary Energy }\end{array}$ & 1 & - & - & 0 \\
\hline & $\begin{array}{l}\text { Use Of Renewable } \\
\text { Primary Energy }\end{array}$ & 1 & $\begin{array}{l}\text { - On-site Renewable } \\
\text { Energy }\end{array}$ & $\begin{array}{l}\text { Energy and } \\
\text { Atmosphere }\end{array}$ & 1 \\
\hline & $\begin{array}{l}\text { Use Of Further Energy } \\
\text { Resources }\end{array}$ & 1 & - Green Power & $\begin{array}{l}\text { Energy and } \\
\text { Atmosphere }\end{array}$ & 1 \\
\hline (1) & $\begin{array}{l}\text { Energy Efficiency of } \\
\text { Building Equipment }\end{array}$ & 1 & $\begin{array}{l}\text { - Fundamental } \\
\text { Refrigerant } \\
\text { Management } \\
\text { - Enhanced } \\
\text { Refrigerant } \\
\text { Management }\end{array}$ & $\begin{array}{l}\text { Energy and } \\
\text { Atmosphere }\end{array}$ & 0.5 \\
\hline & Embodied Energy & 1 & - & - & 0 \\
\hline
\end{tabular}




\begin{tabular}{|c|c|c|c|c|c|}
\hline $\begin{array}{l}\text { Criteria } \\
\text { Group }\end{array}$ & Criteria & $\begin{array}{l}\text { Possible } \\
\text { Points }\end{array}$ & Title Criterion & $\begin{array}{l}\text { In Category } \\
\text { Included }\end{array}$ & Score \\
\hline \multirow{8}{*}{ 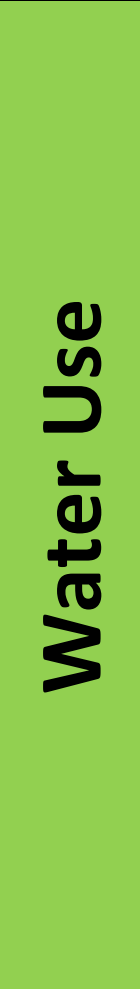 } & Potable Water & 1 & $\begin{array}{l}\text { - Water Efficient } \\
\text { Landscaping } \\
\text { - Innovative } \\
\text { Wastewater } \\
\text { Technologies }\end{array}$ & $\begin{array}{c}\text { Water } \\
\text { Efficiency }\end{array}$ & 1 \\
\hline & $\begin{array}{l}\text { Grey Water / Waste } \\
\text { Water }\end{array}$ & 1 & $\begin{array}{l}\text { - Innovative } \\
\text { Wastewater } \\
\text { Technologies }\end{array}$ & $\begin{array}{l}\text { Water } \\
\text { Efficiency }\end{array}$ & 1 \\
\hline & Storm Water & 1 & $\begin{array}{l}\text { - Stormwater Design } \\
\text { - Quantity Control } \\
\text { - Stormwater Design } \\
\text { - Quality Control }\end{array}$ & $\begin{array}{l}\text { Sustainable } \\
\text { Sites }\end{array}$ & 1 \\
\hline & Runoff & 1 & - & - & 0 \\
\hline & Planting & 1 & $\begin{array}{l}\text { - Water Efficient } \\
\text { Landscaping }\end{array}$ & $\begin{array}{c}\text { Water } \\
\text { Efficiency }\end{array}$ & 1 \\
\hline & $\begin{array}{l}\text { Water Efficiency of } \\
\text { Facility \& Appliances }\end{array}$ & 1 & $\begin{array}{l}\text { - Water Use } \\
\text { Reduction } \\
\text { - Water Use } \\
\text { Reduction }\end{array}$ & $\begin{array}{l}\text { Water } \\
\text { Efficiency }\end{array}$ & 1 \\
\hline & Embodied Water & 1 & - & - & 0 \\
\hline & Water Pollution & 1 & - & - & 0 \\
\hline
\end{tabular}




\begin{tabular}{|c|c|c|c|c|c|}
\hline $\begin{array}{l}\text { Criteria } \\
\text { Group }\end{array}$ & Criteria & $\begin{array}{l}\text { Possible } \\
\text { Points }\end{array}$ & Title Criterion & $\begin{array}{l}\text { In Category } \\
\text { Included }\end{array}$ & Score \\
\hline \multirow[t]{6}{*}{ 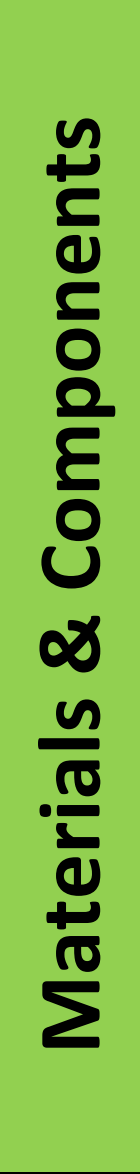 } & $\begin{array}{l}\text { Recycled, Reused } \\
\text { Materials And } \\
\text { Components }\end{array}$ & 1 & $\begin{array}{l}\text { - Storage and } \\
\text { Collection of } \\
\text { Recyclables } \\
\text { - Building Reuse - } \\
\text { Maintain Existing } \\
\text { Walls, Floors and } \\
\text { Roof } \\
\text { - Building Reuse - } \\
\text { Maintain Existing } \\
\text { Interior } \\
\text { Nonstructural } \\
\text { Elements } \\
\text { - Material Reuse } \\
\text { - Recycled Content }\end{array}$ & $\begin{array}{l}\text { Materials } \\
\text { and } \\
\text { Resources }\end{array}$ & 1 \\
\hline & $\begin{array}{l}\text { Modular and } \\
\text { Standardized Materials } \\
\text { And Components }\end{array}$ & 1 & - & - & 0 \\
\hline & $\begin{array}{l}\text { Certified Materials And } \\
\text { Components }\end{array}$ & 1 & $\begin{array}{l}\text { - Rapidly Renewable } \\
\text { Materials } \\
\text { - Certified Wood }\end{array}$ & $\begin{array}{l}\text { Materials } \\
\text { and } \\
\text { Resources }\end{array}$ & 1 \\
\hline & Service Life & 1 & - & - & 0 \\
\hline & Risks From Materials & 1 & - & - & 0 \\
\hline & Local / Regional Material & 1 & - Regional Materials & $\begin{array}{l}\text { Materials } \\
\text { and } \\
\text { Resources }\end{array}$ & 1 \\
\hline
\end{tabular}




\begin{tabular}{|c|c|c|c|c|c|}
\hline $\begin{array}{l}\text { Criteria } \\
\text { Group }\end{array}$ & Criteria & $\begin{array}{l}\text { Possible } \\
\text { Points }\end{array}$ & Title Criterion & $\begin{array}{l}\text { In Category } \\
\text { Included }\end{array}$ & Score \\
\hline \multirow{7}{*}{$\underbrace{n}$} & $\begin{array}{l}\text { Greenhouse Gas - Carbon } \\
\text { Dioxide }\left(\mathrm{CO}_{2}\right)\end{array}$ & 1 & $\begin{array}{l}\text { - Alternative } \\
\text { Transportation - } \\
\text { Low-Emitting and } \\
\text { Fuel-Efficient } \\
\text { Vehicles } \\
\text { - Alternative } \\
\text { Transportation - } \\
\text { Parking Capacity }\end{array}$ & $\begin{array}{l}\text { Sustainable } \\
\text { Sites }\end{array}$ & 0.5 \\
\hline & $\begin{array}{l}\text { Greenhouse Gas - } \\
\text { Methane }\left(\mathrm{CH}_{4}\right)\end{array}$ & 1 & - & - & 0 \\
\hline & $\begin{array}{l}\text { Greenhouse Gas - Nitrous } \\
\text { Oxide }\left(\mathrm{N}_{\mathbf{2}} \mathrm{O}\right)\end{array}$ & 1 & - & - & 0 \\
\hline & $\begin{array}{l}\text { Greenhouse Gas - } \\
\text { Fluorinated Gases }\end{array}$ & 1 & - & - & 0 \\
\hline & Acidification & 1 & - & - & 0 \\
\hline & Ozone Depletion & 1 & $\begin{array}{l}\text { - Fundamental } \\
\text { Refrigerant } \\
\text { Management } \\
\text { - Enhanced } \\
\text { Refrigerant } \\
\text { Management }\end{array}$ & $\begin{array}{l}\text { Energy and } \\
\text { Atmosphere }\end{array}$ & 1 \\
\hline & Pollution & 1 & $\begin{array}{l}\text { - Construction } \\
\text { Activity Pollution } \\
\text { Prevention } \\
\text { - Alternative } \\
\text { Transportation - } \\
\text { Low-Emitting and } \\
\text { Fuel-Efficient } \\
\text { Vehicles } \\
\text { - Alternative } \\
\text { Transportation - } \\
\text { Parking Capacity }\end{array}$ & $\begin{array}{l}\text { Sustainable } \\
\text { Sites }\end{array}$ & 1 \\
\hline
\end{tabular}




\begin{tabular}{|c|c|c|c|c|c|}
\hline $\begin{array}{c}\text { Criteria } \\
\text { Group }\end{array}$ & Criteria & $\begin{array}{c}\text { Possible } \\
\text { Points }\end{array}$ & Title Criterion & $\begin{array}{c}\text { In Category } \\
\text { Included }\end{array}$ & Score \\
\hline \multirow{6}{*}{\begin{tabular}{l}
0 \\
\multirow{2}{*}{} \\
$\sum$ \\
$\sum$
\end{tabular}} & Hazardous Waste & 1 & - & - & 0 \\
\hline & Non-Hazardous Waste & 1 & $\begin{array}{l}\text { - Storage and } \\
\text { Collection of } \\
\text { Recyclables } \\
\end{array}$ & $\begin{array}{l}\text { Materials } \\
\text { and } \\
\text { Resources }\end{array}$ & 1 \\
\hline & Organic Waste & 1 & - & - & 0 \\
\hline & Inorganic Waste & 1 & - & - & 0 \\
\hline & Construction Waste & 1 & $\begin{array}{l}\text { - Construction } \\
\text { Waste } \\
\text { Management }\end{array}$ & $\begin{array}{l}\text { Materials } \\
\text { and } \\
\text { Resources }\end{array}$ & 1 \\
\hline & Radioactive Waste & 1 & - & - & 0 \\
\hline
\end{tabular}




\section{BREEAM:}

\begin{tabular}{|c|c|c|c|c|c|}
\hline $\begin{array}{l}\text { Criteria } \\
\text { Group }\end{array}$ & Criteria & $\begin{array}{l}\text { Possible } \\
\text { Points }\end{array}$ & Title Criterion & $\begin{array}{l}\text { In Category } \\
\text { Included }\end{array}$ & Score \\
\hline \multirow{6}{*}{ ש } & $\begin{array}{l}\text { Site Location, Site } \\
\text { Characteristics }\end{array}$ & 1 & - & - & 0 \\
\hline & Infrastructure & 1 & $\begin{array}{l}\text { - Proximity to } \\
\text { Amenities }\end{array}$ & Infrastructure & 1 \\
\hline & Neighboring Buildings & 1 & - & - & 0 \\
\hline & Heat Island Effect & 1 & - & - & 0 \\
\hline & Landscape Inputs & 1 & $\begin{array}{l}\text { - Hard Landscaping } \\
\text { and Boundary } \\
\text { Protection }\end{array}$ & Materials & 1 \\
\hline & Risk At The Site & 1 & - & - & 0 \\
\hline
\end{tabular}

\begin{tabular}{|c|c|c|c|c|c|}
\hline $\begin{array}{l}\text { Criteria } \\
\text { Group }\end{array}$ & Criteria & $\begin{array}{l}\text { Possible } \\
\text { Points }\end{array}$ & Title Criterion & $\begin{array}{l}\text { In Category } \\
\text { Included }\end{array}$ & Score \\
\hline & Site Ecology & 1 & $\begin{array}{l}\text { - Ecological Value of } \\
\text { Site and } \\
\text { Protection of } \\
\text { Ecological } \\
\text { Features } \\
\text { - Mitigating } \\
\text { Ecological Impact } \\
\text { - Enhancing Site } \\
\text { Ecology }\end{array}$ & $\begin{array}{l}\text { Land Use } \\
\text { and Ecology }\end{array}$ & 1 \\
\hline & Eutrophication & 1 & - & - & 0 \\
\hline 0 & $\begin{array}{l}\text { Habitat Management } \\
\text { Plan }\end{array}$ & 1 & $\begin{array}{l}\text { - Ecological Value of } \\
\text { Site and } \\
\text { Protection of } \\
\text { Ecological } \\
\text { Features }\end{array}$ & $\begin{array}{l}\text { Land Use } \\
\text { and Ecology }\end{array}$ & 1 \\
\hline & Biodiversity & 1 & $\begin{array}{l}\text { - Long Term Impact } \\
\text { on Biodiversity }\end{array}$ & $\begin{array}{l}\text { Land Use } \\
\text { and Ecology }\end{array}$ & 1 \\
\hline
\end{tabular}

\begin{tabular}{|c|l|c|c|c|c|}
\hline $\begin{array}{c}\text { Criteria } \\
\text { Group }\end{array}$ & \multicolumn{1}{|c|}{ Criteria } & $\begin{array}{c}\text { Possible } \\
\text { Points }\end{array}$ & Title Criterion & $\begin{array}{c}\text { In Category } \\
\text { Included }\end{array}$ & Score \\
\hline \multirow{2}{*}{$\boldsymbol{0}$} & Green Field / Brown Field & $\mathbf{1}$ & - Site Selection & $\begin{array}{c}\text { Land Use } \\
\text { and Ecology }\end{array}$ & 1 \\
\cline { 2 - 6 } & $\begin{array}{l}\text { Land Regeneration \& } \\
\text { Development }\end{array}$ & $\mathbf{1}$ & - & - & 0 \\
\hline
\end{tabular}




\begin{tabular}{|c|c|c|c|c|c|}
\hline $\begin{array}{l}\text { Criteria } \\
\text { Group }\end{array}$ & Criteria & $\begin{array}{l}\text { Possible } \\
\text { Points }\end{array}$ & Title Criterion & $\begin{array}{c}\text { In Category } \\
\text { Included }\end{array}$ & Score \\
\hline \multirow{7}{*}{ 둥 } & Total Energy & 1 & $\begin{array}{l}\text { - Construction Site } \\
\text { Impacts - Energy }\end{array}$ & Management & \multirow{2}{*}{1} \\
\hline & Consumption & 1 & $\begin{array}{l}\text { - Consumption } \\
\text { Energy Monitoring }\end{array}$ & Energy & \\
\hline & $\begin{array}{l}\text { Use Of Non-Renewable } \\
\text { Primary Energy }\end{array}$ & 1 & - & - & 0 \\
\hline & $\begin{array}{l}\text { Use Of Renewable } \\
\text { Primary Energy }\end{array}$ & 1 & $\begin{array}{l}\text { - Low and Zero } \\
\text { Carbon } \\
\text { Technologies }\end{array}$ & Energy & 1 \\
\hline & $\begin{array}{l}\text { Use Of Further Energy } \\
\text { Resources }\end{array}$ & 1 & - & - & 0 \\
\hline & $\begin{array}{l}\text { Energy Efficiency of } \\
\text { Building Equipment }\end{array}$ & 1 & $\begin{array}{l}\text { - External Lighting } \\
\text { - Energy Efficient } \\
\text { Cold Storage } \\
\text { - Energy Efficient } \\
\text { Transportation } \\
\text { Systems } \\
\text { - Energy Efficient } \\
\text { Laboratory } \\
\text { Systems } \\
\text { - Energy Efficient } \\
\text { Equipment } \\
\text { - Drying Space } \\
\end{array}$ & Energy & 1 \\
\hline & Embodied Energy & 1 & - Life Cycle Impacts & - & 1 \\
\hline
\end{tabular}




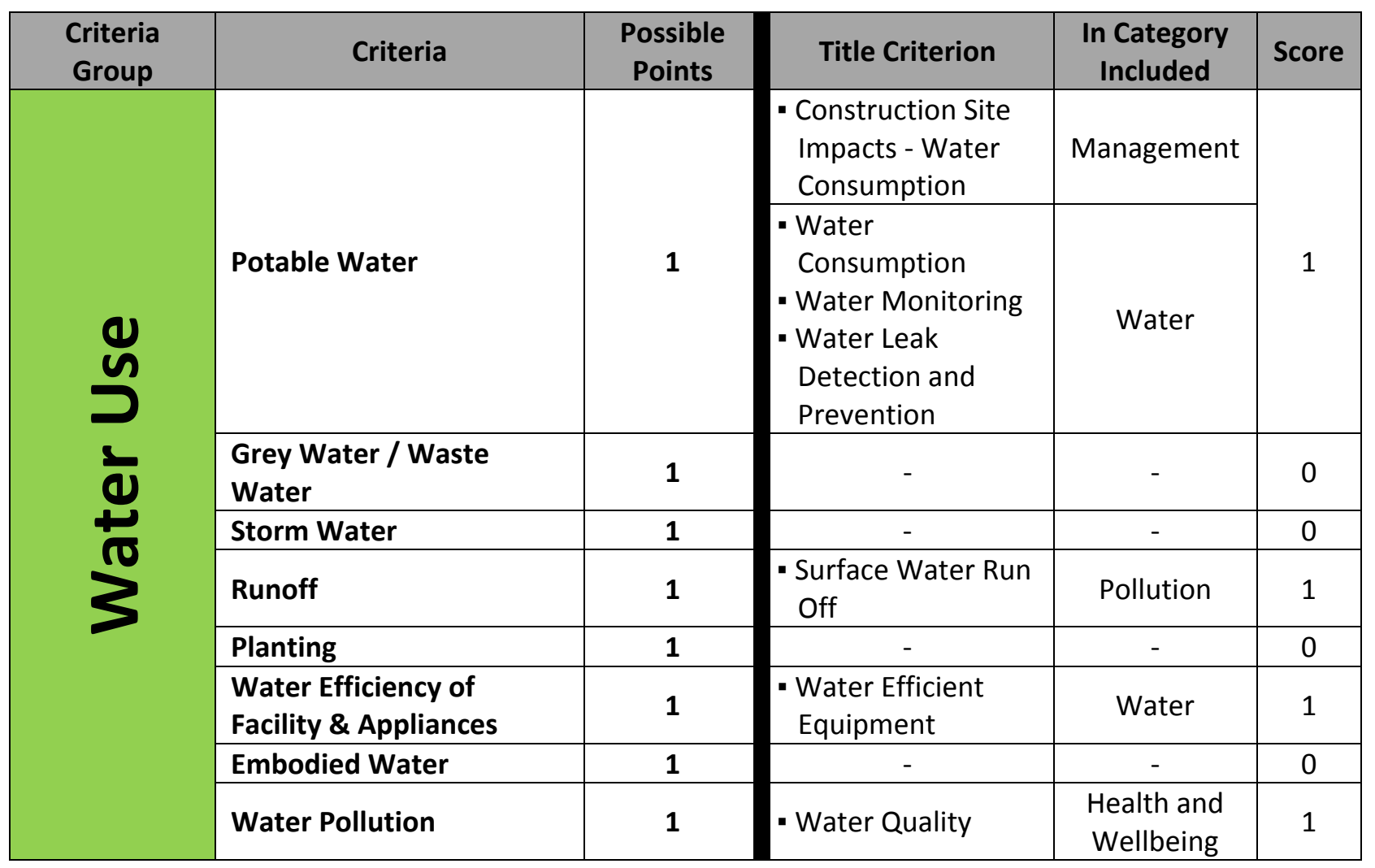

\begin{tabular}{|c|c|c|c|c|c|}
\hline $\begin{array}{l}\text { Criteria } \\
\text { Group }\end{array}$ & Criteria & $\begin{array}{l}\text { Possible } \\
\text { Points }\end{array}$ & Title Criterion & $\begin{array}{l}\text { In Category } \\
\text { Included }\end{array}$ & Score \\
\hline \multirow{8}{*}{$\begin{array}{l}0 \\
0\end{array}$} & Recvcled Reused & & - Life Cycle Impacts & Materials & \\
\hline & $\begin{array}{l}\text { Materials And } \\
\text { Components }\end{array}$ & 1 & $\begin{array}{l}\text { - Recycled } \\
\text { Aggregates } \\
\text { - Operational Waste }\end{array}$ & Waste & 1 \\
\hline & $\begin{array}{l}\text { Modular and } \\
\text { Standardized Materials } \\
\text { And Components }\end{array}$ & 1 & - & - & 0 \\
\hline & & & $\begin{array}{l}\text { - Construction Site } \\
\text { Impact - Timber } \\
\text { Procurement }\end{array}$ & Management & \\
\hline & $\begin{array}{l}\text { Certified Materials And } \\
\text { Components }\end{array}$ & 1 & $\begin{array}{l}\text { - Life Cycle Impacts } \\
\text { - Responsible } \\
\text { Sourcing of } \\
\text { Materials } \\
\text { - Insulation }\end{array}$ & Materials & 1 \\
\hline & Service Life & 1 & - & - & 0 \\
\hline & Risks From Materials & 1 & - & - & 0 \\
\hline & Local / Regional Material & 1 & - & - & 0 \\
\hline
\end{tabular}




\begin{tabular}{|c|c|c|c|c|c|}
\hline $\begin{array}{l}\text { Criteria } \\
\text { Group }\end{array}$ & Criteria & $\begin{array}{l}\text { Possible } \\
\text { Points }\end{array}$ & Title Criterion & $\begin{array}{l}\text { In Category } \\
\text { Included }\end{array}$ & Score \\
\hline \multirow{11}{*}{$\frac{n}{n}$} & \multirow{5}{*}{$\begin{array}{l}\text { Greenhouse Gas - Carbon } \\
\text { Dioxide }\left(\mathrm{CO}_{2}\right)\end{array}$} & \multirow{5}{*}{1} & $\begin{array}{l}\text { - Construction Site } \\
\text { Impact - Transport } \\
\text { of Construction } \\
\text { Materials and } \\
\text { Waste }\end{array}$ & Management & \multirow{5}{*}{1} \\
\hline & & & $\begin{array}{l}\text { - Reduction of } \mathrm{CO}_{2} \\
\text { Emissions }\end{array}$ & Energy & \\
\hline & & & $\begin{array}{l}\text { - Impact of } \\
\text { Refrigerants }\end{array}$ & Pollution & \\
\hline & & & $\begin{array}{l}\text { - Low and Lero } \\
\text { Carbon } \\
\text { Technologies } \\
\text { - Energy Efficient } \\
\text { Cold Storage } \\
\text { - Energy Efficient } \\
\text { Laboratory } \\
\text { Systems }\end{array}$ & Energy & \\
\hline & & & - Life Cycle Impacts & Materials & \\
\hline & $\begin{array}{l}\text { Greenhouse Gas - } \\
\text { Methane }\left(\mathrm{CH}_{4}\right)\end{array}$ & 1 & - & - & 0 \\
\hline & $\begin{array}{l}\text { Greenhouse Gas - Nitrous } \\
\text { Oxide }\left(\mathrm{N}_{2} \mathrm{O}\right)\end{array}$ & 1 & - Nox Emissions & Pollution & 1 \\
\hline & $\begin{array}{l}\text { Greenhouse Gas - } \\
\text { Fluorinated Gases }\end{array}$ & 1 & - & - & 0 \\
\hline & Acidification & 1 & - & - & 0 \\
\hline & Ozone Depletion & 1 & - & - & 0 \\
\hline & Pollution & 1 & - & - & 0 \\
\hline
\end{tabular}

\begin{tabular}{|c|c|c|c|c|c|}
\hline $\begin{array}{l}\text { Criteria } \\
\text { Group }\end{array}$ & Criteria & $\begin{array}{l}\text { Possible } \\
\text { Points }\end{array}$ & Title Criterion & $\begin{array}{l}\text { In Category } \\
\text { Included }\end{array}$ & Score \\
\hline \multirow{6}{*}{$\begin{array}{l}0 \\
0 \\
3 \\
3\end{array}$} & Hazardous Waste & 1 & - & - & 0 \\
\hline & Non-Hazardous Waste & 1 & - & - & 0 \\
\hline & Organic Waste & 1 & - & - & 0 \\
\hline & Inorganic Waste & 1 & - & - & 0 \\
\hline & Construction Waste & 1 & $\begin{array}{l}\text { - Construction } \\
\text { Waste } \\
\text { Management }\end{array}$ & Waste & 1 \\
\hline & Radioactive Waste & 1 & - & - & 0 \\
\hline
\end{tabular}


DGNB:

\begin{tabular}{|c|c|c|c|c|c|}
\hline $\begin{array}{l}\text { Criteria } \\
\text { Group }\end{array}$ & Criteria & $\begin{array}{l}\text { Possible } \\
\text { Points }\end{array}$ & Title Criterion & $\begin{array}{l}\text { In Category } \\
\text { Included }\end{array}$ & Score \\
\hline \multirow[t]{3}{*}{$\frac{5}{0}$} & $\begin{array}{l}\text { Site Location, Site } \\
\text { Characteristics }\end{array}$ & 1 & $\begin{array}{l}\text { - Micro } \\
\text { Environment } \\
\text { - Image and } \\
\text { Conditions of Site } \\
\text { and Neighborhood }\end{array}$ & $\begin{array}{l}\text { Quality of } \\
\text { Location }\end{array}$ & 1 \\
\hline & Infrastructure & 1 & $\begin{array}{l}\text { - Proximity to } \\
\text { Amenities }\end{array}$ & $\begin{array}{l}\text { Quality of } \\
\text { Location }\end{array}$ & 1 \\
\hline & Neighboring Buildings & 1 & - & - & 0 \\
\hline \multirow[t]{3}{*}{ (1) } & Heat Island Effect & 1 & - Roof Design & $\begin{array}{l}\text { Health and } \\
\text { Wellbeing }\end{array}$ & 1 \\
\hline & Landscape Inputs & 1 & - & - & 0 \\
\hline & Risk At The Site & 1 & $\begin{array}{l}\text { - Micro } \\
\text { Environment }\end{array}$ & $\begin{array}{l}\text { Quality of } \\
\text { Location }\end{array}$ & 1 \\
\hline
\end{tabular}

\begin{tabular}{|c|c|c|c|c|c|}
\hline $\begin{array}{l}\text { Criteria } \\
\text { Group }\end{array}$ & Criteria & $\begin{array}{l}\text { Possible } \\
\text { Points }\end{array}$ & Title Criterion & $\begin{array}{l}\text { In Category } \\
\text { Included }\end{array}$ & Score \\
\hline \multirow{4}{*}{ 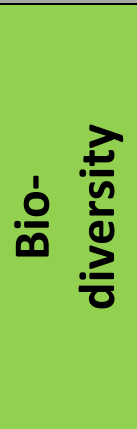 } & Site Ecology & 1 & - & - & 0 \\
\hline & Eutrophication & 1 & $\begin{array}{l}\text { - Life Cycle } \\
\text { Assessment of } \\
\text { Emission Caused } \\
\text { Environmental } \\
\text { Impacts }\end{array}$ & $\begin{array}{l}\text { Global and } \\
\text { Local } \\
\text { Environment }\end{array}$ & 1 \\
\hline & $\begin{array}{l}\text { Habitat Management } \\
\text { Plan }\end{array}$ & 1 & - & - & 0 \\
\hline & Biodiversity & 1 & - & - & 0 \\
\hline
\end{tabular}

\begin{tabular}{|c|c|c|c|c|c|}
\hline $\begin{array}{c}\text { Criteria } \\
\text { Group }\end{array}$ & Criteria & $\begin{array}{c}\text { Possible } \\
\text { Points }\end{array}$ & Title Criterion & $\begin{array}{l}\text { In Category } \\
\text { Included }\end{array}$ & Score \\
\hline \multirow{2}{*}{ 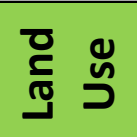 } & Green Field / Brown Field & 1 & \multirow[b]{2}{*}{ - Land Use } & \multirow{2}{*}{$\begin{array}{l}\text { Resources } \\
\text { and Waste }\end{array}$} & 1 \\
\hline & $\begin{array}{l}\text { Land Regeneration \& } \\
\text { Development }\end{array}$ & 1 & & & 1 \\
\hline
\end{tabular}




\begin{tabular}{|c|c|c|c|c|c|}
\hline $\begin{array}{l}\text { Criteria } \\
\text { Group }\end{array}$ & Criteria & $\begin{array}{l}\text { Possible } \\
\text { Points }\end{array}$ & Title Criterion & $\begin{array}{l}\text { In Category } \\
\text { Included }\end{array}$ & Score \\
\hline \multirow{7}{*}{$\begin{array}{l}0 \\
0 \\
0 \\
0 \\
0 \\
0 \\
0\end{array}$} & & & $\begin{array}{l}\text { - Life Cycle } \\
\text { Assessment of } \\
\text { Primary Energy }\end{array}$ & $\begin{array}{l}\text { Resources } \\
\text { and Waste }\end{array}$ & \\
\hline & Consumption & 1 & $\begin{array}{l}\text { - Quality of the } \\
\text { Building Envelope } \\
\text { With Regard to } \\
\text { Heat and Humidity }\end{array}$ & $\begin{array}{c}\text { Technical } \\
\text { Quality }\end{array}$ & 1 \\
\hline & $\begin{array}{l}\text { Use Of Non-Renewable } \\
\text { Primary Energy }\end{array}$ & 1 & \multirow{2}{*}{$\begin{array}{l}\text { - Life Cycle } \\
\text { Assessment of } \\
\text { Primary Energy }\end{array}$} & \multirow{2}{*}{$\begin{array}{l}\text { Resources } \\
\text { and Waste }\end{array}$} & 1 \\
\hline & $\begin{array}{l}\text { Use Of Renewable } \\
\text { Primary Energy }\end{array}$ & 1 & & & 1 \\
\hline & $\begin{array}{l}\text { Use Of Further Energy } \\
\text { Resources }\end{array}$ & 1 & - & - & 0 \\
\hline & $\begin{array}{l}\text { Energy Efficiency of } \\
\text { Building Equipment }\end{array}$ & 1 & - & - & 0 \\
\hline & Embodied Energy & 1 & - & - & 0 \\
\hline
\end{tabular}

\begin{tabular}{|c|c|c|c|c|c|}
\hline $\begin{array}{l}\text { Criteria } \\
\text { Group }\end{array}$ & Criteria & $\begin{array}{l}\text { Possible } \\
\text { Points }\end{array}$ & Title Criterion & $\begin{array}{l}\text { In Category } \\
\text { Included }\end{array}$ & Score \\
\hline \multirow{8}{*}{ (1) } & Potable Water & 1 & \multirow{2}{*}{$\begin{array}{l}\text { - Demand of } \\
\text { Drinking Water } \\
\text { and Volume of } \\
\text { Waste Water } \\
\end{array}$} & \multirow[b]{2}{*}{$\begin{array}{l}\text { Resources } \\
\text { and Waste }\end{array}$} & 1 \\
\hline & $\begin{array}{l}\text { Grey Water / Waste } \\
\text { Water }\end{array}$ & 1 & & & 1 \\
\hline & Storm Water & 1 & - & - & 0 \\
\hline & Runoff & 1 & - & - & 0 \\
\hline & Planting & 1 & - & - & 0 \\
\hline & $\begin{array}{l}\text { Water Efficiency of } \\
\text { Facility \& Appliances }\end{array}$ & 1 & - & - & 0 \\
\hline & Embodied Water & 1 & - & - & 0 \\
\hline & Water Pollution & 1 & - & - & 0 \\
\hline
\end{tabular}




\begin{tabular}{|c|c|c|c|c|c|}
\hline $\begin{array}{l}\text { Criteria } \\
\text { Group }\end{array}$ & Criteria & $\begin{array}{l}\text { Possible } \\
\text { Points }\end{array}$ & Title Criterion & $\begin{array}{l}\text { In Category } \\
\text { Included }\end{array}$ & Score \\
\hline \multirow{6}{*}{4} & $\begin{array}{l}\text { Recycled, Reused } \\
\text { Materials And } \\
\text { Components }\end{array}$ & 1 & - & - & 0 \\
\hline & $\begin{array}{l}\text { Modular and } \\
\text { Standardized Materials } \\
\text { And Components }\end{array}$ & 1 & - & - & 0 \\
\hline & $\begin{array}{l}\text { Certified Materials And } \\
\text { Components }\end{array}$ & 1 & $\begin{array}{l}\text { - Risk for the Local } \\
\text { Environment } \\
\text { - Certified Wood }\end{array}$ & $\begin{array}{l}\text { Materials } \\
\text { and } \\
\text { Resources }\end{array}$ & 1 \\
\hline & Service Life & 1 & - & - & 0 \\
\hline & Risks From Materials & 1 & - & - & 0 \\
\hline & Local / Regional Material & 1 & - & - & 0 \\
\hline
\end{tabular}

\begin{tabular}{|c|c|c|c|c|c|}
\hline $\begin{array}{l}\text { Criteria } \\
\text { Group }\end{array}$ & Criteria & $\begin{array}{l}\text { Possible } \\
\text { Points }\end{array}$ & Title Criterion & $\begin{array}{l}\text { In Category } \\
\text { Included }\end{array}$ & Score \\
\hline \multirow{8}{*}{ ש } & \multirow[t]{2}{*}{$\begin{array}{l}\text { Greenhouse Gas - Carbon } \\
\text { Dioxide }\left(\mathrm{CO}_{2}\right)\end{array}$} & \multirow[t]{2}{*}{1} & $\begin{array}{l}\text { - Life Cycle } \\
\text { Assessment of } \\
\text { Emission Caused } \\
\text { Environmental } \\
\text { Impacts } \\
\end{array}$ & $\begin{array}{c}\text { Global and } \\
\text { Local } \\
\text { Environment }\end{array}$ & \multirow[t]{2}{*}{1} \\
\hline & & & - Roof Design & $\begin{array}{l}\text { Health and } \\
\text { Wellbeing }\end{array}$ & \\
\hline & $\begin{array}{l}\text { Greenhouse Gas - } \\
\text { Methane }\left(\mathrm{CH}_{4}\right)\end{array}$ & 1 & - & - & 0 \\
\hline & $\begin{array}{l}\text { Greenhouse Gas - Nitrous } \\
\text { Oxide }\left(\mathrm{N}_{2} \mathrm{O}\right)\end{array}$ & 1 & - & - & 0 \\
\hline & $\begin{array}{l}\text { Greenhouse Gas - } \\
\text { Fluorinated Gases }\end{array}$ & 1 & - & - & 0 \\
\hline & Acidification & 1 & \multirow{2}{*}{$\begin{array}{l}\text { - Life Cycle } \\
\text { Assessment of } \\
\text { Emission Caused } \\
\text { Environmental } \\
\text { Impacts } \\
\end{array}$} & \multirow[b]{2}{*}{$\begin{array}{l}\text { Global and } \\
\text { Local } \\
\text { Environment }\end{array}$} & 1 \\
\hline & Ozone Depletion & 1 & & & 1 \\
\hline & Pollution & 1 & - & - & 0 \\
\hline
\end{tabular}




\begin{tabular}{|c|c|c|c|c|c|}
\hline $\begin{array}{l}\text { Criteria } \\
\text { Group }\end{array}$ & Criteria & $\begin{array}{l}\text { Possible } \\
\text { Points }\end{array}$ & Title Criterion & $\begin{array}{l}\text { In Category } \\
\text { Included }\end{array}$ & Score \\
\hline \multirow{6}{*}{$\begin{array}{l}\text { (1) } \\
\text { (1) } \\
\end{array}$} & Hazardous Waste & 1 & - & - & 0 \\
\hline & Non-Hazardous Waste & 1 & - & - & 0 \\
\hline & Organic Waste & 1 & - & - & 0 \\
\hline & Inorganic Waste & 1 & - & - & 0 \\
\hline & Construction Waste & 1 & - & - & 0 \\
\hline & Radioactive Waste & 1 & - & - & 0 \\
\hline
\end{tabular}




\section{APPENDIX C}

\section{LEED:}

\begin{tabular}{|c|c|c|c|c|c|}
\hline $\begin{array}{l}\text { Criteria } \\
\text { Group }\end{array}$ & Criteria & $\begin{array}{l}\text { Possible } \\
\text { Points }\end{array}$ & Title Criterion & $\begin{array}{l}\text { In Category } \\
\text { Included }\end{array}$ & Score \\
\hline \multirow{6}{*}{$\frac{60}{1}$} & $\begin{array}{l}\text { Total Energy } \\
\text { Consumption }\end{array}$ & 1 & $\begin{array}{l}\text { - Minimum Energy } \\
\text { Performance } \\
\text { - Optimize Energy } \\
\text { Performance } \\
\text { - Measurement } \\
\text { and Verification }\end{array}$ & $\begin{array}{l}\text { Energy and } \\
\text { Atmosphere }\end{array}$ & 1 \\
\hline & $\begin{array}{l}\text { Use Of Non-Renewable } \\
\text { Primary Energy }\end{array}$ & 1 & - & - & 0 \\
\hline & $\begin{array}{l}\text { Use Of Renewable } \\
\text { Primary Energy }\end{array}$ & 1 & $\begin{array}{l}\text { - On-site } \\
\text { Renewable Energy }\end{array}$ & $\begin{array}{l}\text { Energy and } \\
\text { Atmosphere }\end{array}$ & 1 \\
\hline & $\begin{array}{l}\text { Use Of Further Energy } \\
\text { Resources }\end{array}$ & 1 & - Green Power & $\begin{array}{l}\text { Energy and } \\
\text { Atmosphere }\end{array}$ & 1 \\
\hline & $\begin{array}{l}\text { Energy Efficiency of } \\
\text { Building Equipment }\end{array}$ & 1 & $\begin{array}{l}\text { - Fundamental } \\
\text { Refrigerant } \\
\text { Management } \\
\text { - Enhanced } \\
\text { Refrigerant } \\
\text { Management } \\
\end{array}$ & $\begin{array}{l}\text { Energy and } \\
\text { Atmosphere }\end{array}$ & 0.5 \\
\hline & Embodied Energy & 1 & - & - & 0 \\
\hline
\end{tabular}




\begin{tabular}{|c|c|c|c|c|c|}
\hline $\begin{array}{l}\text { Criteria } \\
\text { Group }\end{array}$ & Criteria & $\begin{array}{l}\text { Possible } \\
\text { Points }\end{array}$ & Title Criterion & $\begin{array}{l}\text { In Category } \\
\text { Included }\end{array}$ & Score \\
\hline \multirow[t]{4}{*}{ 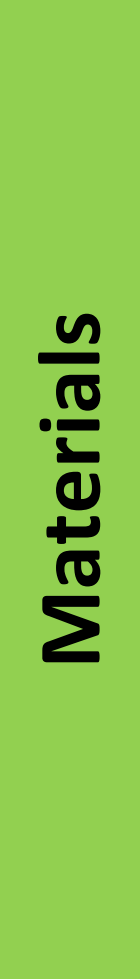 } & $\begin{array}{l}\text { Recycled, Reused } \\
\text { Materials And } \\
\text { Components }\end{array}$ & 1 & $\begin{array}{l}\text { - Storage and } \\
\text { Collection of } \\
\text { Recyclables } \\
\text { - Building Reuse - } \\
\text { Maintain Existing } \\
\text { Walls, Floors and } \\
\text { Roof } \\
\text { - Building Reuse - } \\
\text { Maintain Existing } \\
\text { Interior } \\
\text { Nonstructural } \\
\text { Elements } \\
\text { - Material Reuse } \\
\text { - Recycled Content }\end{array}$ & $\begin{array}{l}\text { Materials } \\
\text { and } \\
\text { Resources }\end{array}$ & 1 \\
\hline & $\begin{array}{l}\text { Certified Materials And } \\
\text { Components }\end{array}$ & 1 & $\begin{array}{l}\text { - Rapidly Renewable } \\
\text { Materials } \\
\text { - Certified Wood }\end{array}$ & $\begin{array}{l}\text { Materials } \\
\text { and } \\
\text { Resources }\end{array}$ & 1 \\
\hline & Risks From Materials & 1 & - & - & 0 \\
\hline & Local / Regional Material & 1 & - Regional Materials & $\begin{array}{l}\text { Materials } \\
\text { and } \\
\text { Resources }\end{array}$ & 1 \\
\hline
\end{tabular}




\begin{tabular}{|c|c|c|c|c|c|}
\hline $\begin{array}{l}\text { Criteria } \\
\text { Group }\end{array}$ & Criteria & $\begin{array}{l}\text { Possible } \\
\text { Points }\end{array}$ & Title Criterion & $\begin{array}{l}\text { In Category } \\
\text { Included }\end{array}$ & Score \\
\hline \multirow{8}{*}{$\begin{array}{l}0 \\
00 \\
\frac{c}{\sigma}\end{array}$} & $\begin{array}{l}\text { Greenhouse Gas - Carbon } \\
\text { Dioxide }\left(\mathrm{CO}_{2}\right)\end{array}$ & 1 & $\begin{array}{l}\text { - Alternative } \\
\text { Transportation - } \\
\text { Low-Emitting and } \\
\text { Fuel-Efficient } \\
\text { Vehicles } \\
\text { - Alternative } \\
\text { Transportation - } \\
\text { Parking Capacity }\end{array}$ & $\begin{array}{l}\text { Sustainable } \\
\text { Sites }\end{array}$ & 1 \\
\hline & $\begin{array}{l}\text { Greenhouse Gas - } \\
\text { Methane }\left(\mathrm{CH}_{4}\right)\end{array}$ & 1 & - & - & 0 \\
\hline & $\begin{array}{l}\text { Greenhouse Gas - Nitrous } \\
\text { Oxide }\left(\mathrm{N}_{2} \mathrm{O}\right)\end{array}$ & 1 & - & - & 0 \\
\hline & $\begin{array}{l}\text { Greenhouse Gas - } \\
\text { Fluorinated Gases }\end{array}$ & 1 & - & - & 0 \\
\hline & Pollution & 1 & $\begin{array}{l}\text { Construction } \\
\text { Activity Pollution } \\
\text { Prevention } \\
\text { Alternative } \\
\text { Transportation - } \\
\text { Low-Emitting and } \\
\text { Fuel-Efficient } \\
\text { Vehicles } \\
\text { - Alternative } \\
\text { Transportation - } \\
\text { Parking Capacity }\end{array}$ & $\begin{array}{l}\text { Sustainable } \\
\text { Sites }\end{array}$ & 1 \\
\hline & Acidification & 1 & - & - & 0 \\
\hline & Ozone Depletion & 1 & $\begin{array}{l}\text { Fundamental } \\
\text { Refrigerant } \\
\text { Management } \\
\text { Enhanced } \\
\text { Refrigerant } \\
\text { Management }\end{array}$ & $\begin{array}{l}\text { Energy and } \\
\text { Atmosphere }\end{array}$ & 1 \\
\hline & Eutrophication & 1 & - & - & 0 \\
\hline
\end{tabular}




\begin{tabular}{|c|c|c|c|c|c|}
\hline $\begin{array}{l}\text { Criteria } \\
\text { Group }\end{array}$ & Criteria & $\begin{array}{l}\text { Possible } \\
\text { Points }\end{array}$ & Title Criterion & $\begin{array}{l}\text { In Category } \\
\text { Included }\end{array}$ & Score \\
\hline \multirow{6}{*}{6} & Green Field / Brown Field & 1 & $\begin{array}{l}\text { - Brownfield } \\
\text { Development }\end{array}$ & $\begin{array}{l}\text { Sustainable } \\
\text { Sites }\end{array}$ & 1 \\
\hline & $\begin{array}{l}\text { Land Regeneration \& } \\
\text { Development }\end{array}$ & 1 & $\begin{array}{l}\text { - Alternative } \\
\text { Transportation - } \\
\text { Low-Emitting and } \\
\text { Fuel-Efficient } \\
\text { Vehicles } \\
\text { - Alternative } \\
\text { Transportation - } \\
\text { Parking Capacity }\end{array}$ & $\begin{array}{l}\text { Sustainable } \\
\text { Sites }\end{array}$ & 1 \\
\hline & Site Ecology & 1 & - & - & 0 \\
\hline & $\begin{array}{l}\text { Site Location, Site } \\
\text { Characteristics }\end{array}$ & 1 & $\begin{array}{l}\text { - Site Selection } \\
\text { - Site Development } \\
\text { - Maximize Open } \\
\text { Space }\end{array}$ & $\begin{array}{l}\text { Sustainable } \\
\text { Sites }\end{array}$ & 1 \\
\hline & $\begin{array}{l}\text { Habitat Management } \\
\text { Plan }\end{array}$ & 1 & $\begin{array}{l}\text { - Site Development } \\
\text { - Protect or }\end{array}$ & Sustainable & 1 \\
\hline & Biodiversity & 1 & Restore Habitat & & 1 \\
\hline
\end{tabular}




\begin{tabular}{|c|c|c|c|c|c|}
\hline $\begin{array}{l}\text { Criteria } \\
\text { Group }\end{array}$ & Criteria & $\begin{array}{c}\text { Possible } \\
\text { Points }\end{array}$ & Title Criterion & $\begin{array}{l}\text { In Category } \\
\text { Included }\end{array}$ & Score \\
\hline \multirow{8}{*}{$\sum_{3}^{10}$} & Potable Water & 1 & $\begin{array}{l}\text { - Water Efficient } \\
\text { Landscaping } \\
\text { - Innovative } \\
\text { Wastewater } \\
\text { Technologies }\end{array}$ & $\begin{array}{l}\text { Water } \\
\text { Efficiency }\end{array}$ & 1 \\
\hline & $\begin{array}{l}\text { Grey Water / Waste } \\
\text { Water }\end{array}$ & 1 & $\begin{array}{l}\text { - Innovative } \\
\text { Wastewater } \\
\text { Technologies }\end{array}$ & $\begin{array}{l}\text { Water } \\
\text { Efficiency }\end{array}$ & 1 \\
\hline & Storm Water & 1 & $\begin{array}{l}\text { - Stormwater Design } \\
\text { - Quantity Control } \\
\text { - Stormwater Design } \\
\text { - Quality Control }\end{array}$ & $\begin{array}{l}\text { Sustainable } \\
\text { Sites }\end{array}$ & 1 \\
\hline & $\begin{array}{l}\text { Water Efficiency of } \\
\text { Facility \& Appliances }\end{array}$ & 1 & $\begin{array}{l}\text { - Water Use } \\
\text { Reduction } \\
\text { - Water Use } \\
\text { Reduction }\end{array}$ & $\begin{array}{l}\text { Water } \\
\text { Efficiency }\end{array}$ & 1 \\
\hline & Runoff & 1 & - & - & 0 \\
\hline & Planting & 1 & $\begin{array}{l}\text { - Water Efficient } \\
\text { Landscaping }\end{array}$ & $\begin{array}{c}\text { Water } \\
\text { Efficiency }\end{array}$ & 1 \\
\hline & Embodied Water & 1 & - & - & 0 \\
\hline & Water Pollution & 1 & - & - & 0 \\
\hline
\end{tabular}

\begin{tabular}{|c|c|c|c|c|c|}
\hline $\begin{array}{l}\text { Criteria } \\
\text { Group }\end{array}$ & Criteria & $\begin{array}{l}\text { Possible } \\
\text { Points }\end{array}$ & Title Criterion & $\begin{array}{l}\text { In Category } \\
\text { Included }\end{array}$ & Score \\
\hline \multirow{5}{*}{ 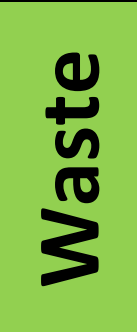 } & Hazardous Waste & 1 & - & - & 0 \\
\hline & Non-Hazardous Waste & 1 & $\begin{array}{l}\text { - Storage and } \\
\text { Collection of } \\
\text { Recyclables }\end{array}$ & $\begin{array}{l}\text { Materials } \\
\text { and } \\
\text { Resources }\end{array}$ & 1 \\
\hline & Organic Waste & 1 & - & - & 0 \\
\hline & Inorganic Waste & 1 & - & - & 0 \\
\hline & Radioactive Waste & 1 & - & - & 0 \\
\hline
\end{tabular}




\begin{tabular}{|c|c|c|c|c|c|}
\hline $\begin{array}{l}\text { Criteria } \\
\text { Group }\end{array}$ & Criteria & $\begin{array}{c}\text { Possible } \\
\text { Points }\end{array}$ & Title Criterion & $\begin{array}{l}\text { In Category } \\
\text { Included }\end{array}$ & Score \\
\hline \multirow{6}{*}{ U) } & Initial Costs & 1 & - & - & 0 \\
\hline & $\begin{array}{l}\text { Costs For Operation, } \\
\text { Maintenance And Repair }\end{array}$ & 1 & $\begin{array}{l}\text { - Minimum Energy } \\
\text { Performance } \\
\text { - On-site Renewable } \\
\text { Energy }\end{array}$ & $\begin{array}{l}\text { Energy and } \\
\text { Atmosphere }\end{array}$ & 1 \\
\hline & Replacement Costs & 1 & - & - & 0 \\
\hline & $\begin{array}{l}\text { Risk \& Value } \\
\text { Management }\end{array}$ & 1 & - & - & 0 \\
\hline & Function Analysis & 1 & - & - & 0 \\
\hline & Payback Time & 1 & - & - & 0 \\
\hline
\end{tabular}

\begin{tabular}{|c|c|c|c|c|c|}
\hline $\begin{array}{l}\text { Criteria } \\
\text { Group }\end{array}$ & Criteria & $\begin{array}{l}\text { Possible } \\
\text { Points }\end{array}$ & Title Criterion & $\begin{array}{l}\text { In Category } \\
\text { Included }\end{array}$ & Score \\
\hline \multirow{7}{*}{ है } & Demand Of Space & 1 & - & - & 0 \\
\hline & Area Efficiency & 1 & - & - & 0 \\
\hline & Capacity & 1 & - & - & 0 \\
\hline & Occupancy & 1 & - & - & 0 \\
\hline & Longevity & 1 & - & - & 0 \\
\hline & $\begin{array}{l}\text { Adaptability And } \\
\text { Versatility }\end{array}$ & 1 & - & - & 0 \\
\hline & $\begin{array}{l}\text { Demolition / Reuse / } \\
\text { Recycling }\end{array}$ & 1 & - & - & \\
\hline
\end{tabular}




\begin{tabular}{|c|c|c|c|c|c|}
\hline $\begin{array}{l}\text { Criteria } \\
\text { Group }\end{array}$ & Criteria & $\begin{array}{l}\text { Possible } \\
\text { Points }\end{array}$ & Title Criterion & $\begin{array}{c}\text { In Category } \\
\text { Included }\end{array}$ & Score \\
\hline \multirow{13}{*}{ 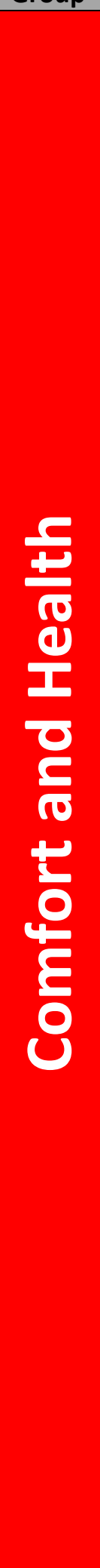 } & Daylighting & 1 & $\begin{array}{l}\text { - Daylight and Views } \\
\text { - Daylight }\end{array}$ & $\begin{array}{c}\text { Indoor } \\
\text { Environment } \\
\text { Quality }\end{array}$ & 1 \\
\hline & Illumination & 1 & - & - & 0 \\
\hline & $\begin{array}{l}\text { Lighting Zones And } \\
\text { Control: Lighting For } \\
\text { Suitable Tasks In Lux }\end{array}$ & 1 & $\begin{array}{l}\text { - Controllability of } \\
\text { Systems - Lighting }\end{array}$ & $\begin{array}{c}\text { Indoor } \\
\text { Environment } \\
\text { Quality } \\
\end{array}$ & 1 \\
\hline & Natural Lighting \& Glare & 1 & $\begin{array}{l}\text { - Light Pollution } \\
\text { Reduction }\end{array}$ & $\begin{array}{l}\text { Sustainable } \\
\text { Sites }\end{array}$ & 1 \\
\hline & Thermal Comfort & 1 & $\begin{array}{l}\text { - Thermal Comfort - } \\
\text { Design } \\
\text { - Thermal Comfort - } \\
\text { Verification }\end{array}$ & $\begin{array}{c}\text { Indoor } \\
\text { Environment } \\
\text { Quality }\end{array}$ & 1 \\
\hline & $\begin{array}{l}\text { Air Temperature And } \\
\text { Relative Humidity }\end{array}$ & 1 & $\begin{array}{l}\text { - Minimum Indoor } \\
\text { Air Quality } \\
\text { Performance } \\
\end{array}$ & $\begin{array}{c}\text { Indoor } \\
\text { Environment } \\
\text { Quality } \\
\end{array}$ & 1 \\
\hline & $\begin{array}{l}\text { Summer / Winter } \\
\text { Conditions }\end{array}$ & 1 & - & - & 0 \\
\hline & Thermal Zoning & 1 & $\begin{array}{l}\text { - Controllability of } \\
\text { Systems - Thermal } \\
\text { Comfort }\end{array}$ & $\begin{array}{c}\text { Indoor } \\
\text { Environment } \\
\text { Quality }\end{array}$ & 1 \\
\hline & $\begin{array}{l}\text { Noise From Building And } \\
\text { Site }\end{array}$ & 1 & - & - & 0 \\
\hline & Background Noise Level & 1 & - & - & 0 \\
\hline & Reverberation Time & 1 & - & - & 0 \\
\hline & $\begin{array}{l}\text { Indoor Air Pollutants } \\
\text { Concentration }\end{array}$ & 1 & $\begin{array}{l}\text { - Low-Emitting } \\
\text { Materials - } \\
\text { Adhesives and } \\
\text { Sealants } \\
\text { - Low-Emitting } \\
\text { Materials - Paints } \\
\text { and Coatings } \\
\text { - Low-Emitting } \\
\text { Materials } \\
\text { Flooring Systems } \\
\text { - Low-Emitting } \\
\text { Materials - } \\
\text { Composite Wood } \\
\text { and Agrifiber } \\
\text { Products } \\
\text { - Indoor Chemical } \\
\text { and Pollutant } \\
\text { Source Control }\end{array}$ & $\begin{array}{c}\text { Indoor } \\
\text { Environment } \\
\text { Quality }\end{array}$ & 1 \\
\hline & Ventilation Conditions & 1 & - Minimum Indoor & Indoor & 1 \\
\hline
\end{tabular}




\begin{tabular}{|c|c|c|c|c|}
\hline & & $\begin{array}{l}\text { Air Quality } \\
\text { Performance } \\
\text { - Outdoor Air } \\
\text { Delivery } \\
\text { Monitoring } \\
\text { - Increased } \\
\text { Ventilation }\end{array}$ & $\begin{array}{c}\text { Environment } \\
\text { Quality }\end{array}$ & \\
\hline Mold Growth Risk & 1 & - & - & 0 \\
\hline $\begin{array}{l}\mathrm{CO}_{2} \text {, Formaldehyde and } \\
\text { Nitrogen Oxide } \\
\text { Concentration }\end{array}$ & 1 & $\begin{array}{l}\text { - Environmental } \\
\text { Tobacco Smoke } \\
\text { (ETS) Control } \\
\text { Outdoor Air } \\
\text { Delivery } \\
\text { Monitoring }\end{array}$ & $\begin{array}{l}\text { Indoor } \\
\text { Environment } \\
\text { Quality }\end{array}$ & 1 \\
\hline Access To View & 1 & $\begin{array}{l}\text { - Daylight and Views } \\
\text { - Views }\end{array}$ & $\begin{array}{c}\text { Indoor } \\
\text { Environment } \\
\text { Quality }\end{array}$ & 1 \\
\hline Privacy & 1 & - & - & 0 \\
\hline Feelings And Sensations & 1 & - & - & 0 \\
\hline Recreation & 1 & - & - & 0 \\
\hline $\begin{array}{l}\text { Human Interactions / } \\
\text { Relationships }\end{array}$ & 1 & - & - & 0 \\
\hline Interior Qualities & 1 & - & - & 0 \\
\hline
\end{tabular}




\begin{tabular}{|c|c|c|c|c|c|}
\hline $\begin{array}{l}\text { Criteria } \\
\text { Group }\end{array}$ & Criteria & $\begin{array}{l}\text { Possible } \\
\text { Points }\end{array}$ & Title Criterion & $\begin{array}{l}\text { In Category } \\
\text { Included }\end{array}$ & Score \\
\hline 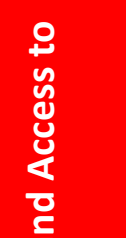 & $\begin{array}{l}\text { Public \& Public } \\
\text { Transport Accessibility }\end{array}$ & 1 & $\begin{array}{l}\text { - Alternative } \\
\text { Transportation - } \\
\text { Public } \\
\text { Transportation } \\
\text { Access }\end{array}$ & $\begin{array}{l}\text { Sustainable } \\
\text { Sites }\end{array}$ & 1 \\
\hline$\stackrel{\text { 응 }}{\frac{0}{0}}$ & $\begin{array}{l}\text { Barrier-Free } \\
\text { Accessibility }\end{array}$ & 1 & - & - & 0 \\
\hline 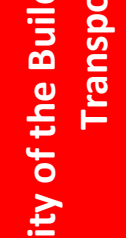 & Bicycle Comfort & 1 & $\begin{array}{l}\text { - Alternative } \\
\text { Transportation - } \\
\text { Bicycle Storage } \\
\text { and Changing } \\
\text { Rooms } \\
\end{array}$ & $\begin{array}{c}\text { Sustainable } \\
\text { Sites }\end{array}$ & 1 \\
\hline 흘 & Pedestrian Comfort & 1 & - & - & 0 \\
\hline لुّ & Car Parking Capacity & 1 & $\begin{array}{l}\text { - Alternative } \\
\text { Transportation - } \\
\text { Parking Capacity }\end{array}$ & $\begin{array}{l}\text { Sustainable } \\
\text { Sites }\end{array}$ & 1 \\
\hline
\end{tabular}

\begin{tabular}{|c|c|c|c|c|c|}
\hline $\begin{array}{l}\text { Criteria } \\
\text { Group }\end{array}$ & Criteria & $\begin{array}{l}\text { Possible } \\
\text { Points }\end{array}$ & Title Criterion & $\begin{array}{l}\text { In Category } \\
\text { Included }\end{array}$ & Score \\
\hline \multirow{7}{*}{ 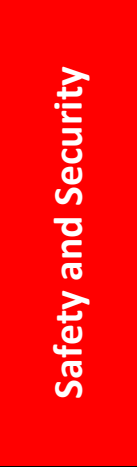 } & Safety Assessment & 1 & - & - & 0 \\
\hline & Safety Management & 1 & - & - & 0 \\
\hline & Site And Building & 1 & - & - & 0 \\
\hline & Combustion Sources & 1 & - & - & 0 \\
\hline & $\begin{array}{l}\text { Resistance - Storm, } \\
\text { High Water }\end{array}$ & 1 & - & - & 0 \\
\hline & Resistance - Hail & 1 & - & - & 0 \\
\hline & $\begin{array}{l}\text { Resistance - } \\
\text { Earthquake }\end{array}$ & 1 & - & - & 0 \\
\hline
\end{tabular}




\begin{tabular}{|c|c|c|c|c|c|}
\hline $\begin{array}{l}\text { Criteria } \\
\text { Group }\end{array}$ & Criteria & $\begin{array}{l}\text { Possible } \\
\text { Points }\end{array}$ & Title Criterion & $\begin{array}{l}\text { In Category } \\
\text { Included }\end{array}$ & Score \\
\hline \multirow{4}{*}{ 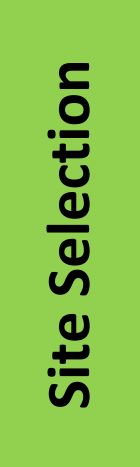 } & Infrastructure & 0.5 & $\begin{array}{l}\text { - Development } \\
\text { Density and } \\
\text { Community } \\
\text { Connectivity } \\
\end{array}$ & $\begin{array}{c}\text { Sustainable } \\
\text { Sites }\end{array}$ & 0.5 \\
\hline & Heat Island Effect & 0.5 & $\begin{array}{l}\text { - Heat Island Effect } \\
\text { - Nonroof } \\
\text { - Heat Island Effect } \\
\text { - Roof }\end{array}$ & $\begin{array}{c}\text { Sustainable } \\
\text { Sites }\end{array}$ & 0.5 \\
\hline & Landscape Inputs & 0.5 & - & - & 0 \\
\hline & Risk At The Site & 0.5 & - & - & 0 \\
\hline
\end{tabular}

\begin{tabular}{|c|c|c|c|c|c|}
\hline $\begin{array}{c}\text { Criteria } \\
\text { Group }\end{array}$ & Criteria & $\begin{array}{c}\text { Possible } \\
\text { Points }\end{array}$ & Title Criterion & $\begin{array}{c}\text { In Category } \\
\text { Included }\end{array}$ & Score \\
\hline \multirow[b]{2}{*}{ 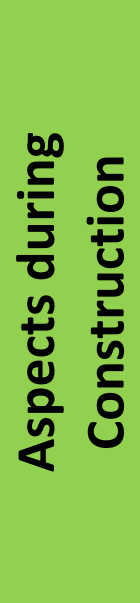 } & Construction Waste & 0.5 & $\begin{array}{l}\text { - Construction } \\
\text { Waste } \\
\text { Management }\end{array}$ & $\begin{array}{l}\text { Materials } \\
\text { and } \\
\text { Resources }\end{array}$ & 0.5 \\
\hline & $\begin{array}{l}\text { Construction Indoor Air } \\
\text { Quality }\end{array}$ & 0.5 & $\begin{array}{l}\text { - Construction } \\
\text { Indoor Air Quality } \\
\text { Management Plan } \\
\text { - During } \\
\text { Construction } \\
\text { - Construction } \\
\text { Indoor Air Quality } \\
\text { Management Plan } \\
\text { - Before } \\
\text { Occupancy }\end{array}$ & $\begin{array}{c}\text { Indoor } \\
\text { Environment } \\
\text { Quality }\end{array}$ & 0.5 \\
\hline
\end{tabular}




\begin{tabular}{|c|c|c|c|c|c|c|}
\hline \multicolumn{2}{|c|}{$\begin{array}{c}\text { Criteria } \\
\text { Group }\end{array}$} & Criteria & $\begin{array}{c}\text { Possible } \\
\text { Points }\end{array}$ & Title Criterion & $\begin{array}{c}\text { In } \\
\text { Category } \\
\text { Included } \\
\end{array}$ & Score \\
\hline \multirow{4}{*}{ 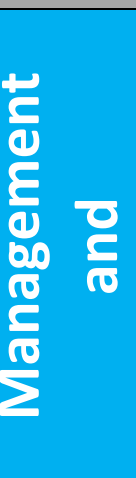 } & \multirow{4}{*}{ 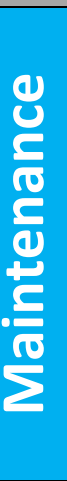 } & $\begin{array}{l}\text { Building User Guide, } \\
\text { Awareness \& Education }\end{array}$ & 0.5 & - & - & 0 \\
\hline & & $\begin{array}{l}\text { Establishing } \\
\text { Preconditions For An } \\
\text { Optimized Use And } \\
\text { Operation }\end{array}$ & 0.5 & - & - & 0 \\
\hline & & $\begin{array}{l}\text { Maintainability And } \\
\text { Operation Comfort }\end{array}$ & 0.5 & - & - & 0 \\
\hline & & $\begin{array}{l}\text { Intelligence And } \\
\text { Controllability }\end{array}$ & 0.5 & - & - & 0 \\
\hline
\end{tabular}

\begin{tabular}{|c|c|c|c|c|c|}
\hline $\begin{array}{l}\text { Criteria } \\
\text { Group }\end{array}$ & Criteria & $\begin{array}{l}\text { Possible } \\
\text { Points }\end{array}$ & Title Criterion & $\begin{array}{l}\text { In Category } \\
\text { Included }\end{array}$ & Score \\
\hline \multirow{5}{*}{ 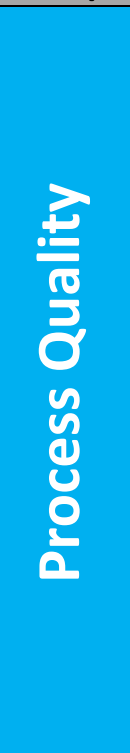 } & $\begin{array}{l}\text { Integral Planning, } \\
\text { Integrated Design }\end{array}$ & 0.5 & $\begin{array}{l}\text { - LEED Accredited } \\
\text { Professional }\end{array}$ & $\begin{array}{l}\text { Innovation } \\
\text { in Design }\end{array}$ & 0.5 \\
\hline & $\begin{array}{l}\text { Optimization And } \\
\text { Complexity Of The } \\
\text { Planning Approach }\end{array}$ & 0.5 & - & - & 0 \\
\hline & $\begin{array}{l}\text { Quality Of Project's } \\
\text { Preparation }\end{array}$ & 0.5 & - & - & 0 \\
\hline & $\begin{array}{l}\text { Quality Of The Executing } \\
\text { Contractors / } \\
\text { Prequalification }\end{array}$ & 0.5 & - & - & 0 \\
\hline & $\begin{array}{l}\text { Controlled } \\
\text { Commissioning }\end{array}$ & 0.5 & $\begin{array}{l}\text { - Fundamental } \\
\text { Commissioning of } \\
\text { Building Energy } \\
\text { Systems } \\
\text { - Enhanced } \\
\text { Commissioning }\end{array}$ & $\begin{array}{l}\text { Energy and } \\
\text { Atmosphere }\end{array}$ & 0.5 \\
\hline
\end{tabular}

\begin{tabular}{|c|c|c|c|c|c|}
\hline $\begin{array}{c}\text { Criteria } \\
\text { Group }\end{array}$ & Criteria & $\begin{array}{c}\text { Possible } \\
\text { Points }\end{array}$ & Title Criterion & $\begin{array}{c}\text { In Category } \\
\text { Included }\end{array}$ & Score \\
\hline Innovation & $\begin{array}{l}\text { Innovations, Innovative } \\
\text { Strategies \& Technologies }\end{array}$ & $\mathbf{0 . 5}$ & $\begin{array}{c}\text { - Innovation in } \\
\text { Design }\end{array}$ & $\begin{array}{c}\text { Innovation in } \\
\text { Design }\end{array}$ & 0.5 \\
\hline
\end{tabular}




\begin{tabular}{|c|c|c|c|c|c|}
\hline $\begin{array}{c}\text { Criteria } \\
\text { Group }\end{array}$ & \multicolumn{1}{|c|}{ Criteria } & $\begin{array}{c}\text { Possible } \\
\text { Points }\end{array}$ & Title Criterion & $\begin{array}{c}\text { In Category } \\
\text { Included }\end{array}$ & Score \\
\hline Usability & $\begin{array}{l}\text { Communications And } \\
\text { Mobility }\end{array}$ & 0.5 & - & - & 0 \\
\hline
\end{tabular}

\begin{tabular}{|c|c|c|c|c|c|}
\hline Criteria Group & Criteria & $\begin{array}{l}\text { Possible } \\
\text { Points }\end{array}$ & Title Criterion & $\begin{array}{l}\text { In Category } \\
\text { Included }\end{array}$ & Score \\
\hline \multirow{3}{*}{$\begin{array}{c}\text { Further } \\
\text { Environmental } \\
\text { Criteria }\end{array}$} & Neighboring Buildings & 0.25 & - & - & 0 \\
\hline & $\begin{array}{l}\text { Modular and } \\
\text { Standardized Materials } \\
\text { And Components }\end{array}$ & 0.25 & - & - & 0 \\
\hline & Service Life & 0.25 & - & - & 0 \\
\hline
\end{tabular}

\begin{tabular}{|c|l|c|c|c|c|}
\hline Criteria Group & \multicolumn{1}{|c|}{ Criteria } & $\begin{array}{c}\text { Possible } \\
\text { Points }\end{array}$ & Title Criterion & $\begin{array}{c}\text { In Category } \\
\text { Included }\end{array}$ & Score \\
\hline $\begin{array}{l}\text { Further Indoor } \\
\text { Environmental } \\
\text { Criteria }\end{array}$ & $\begin{array}{l}\text { Electromagnetic } \\
\text { Emissions }\end{array}$ & $\begin{array}{l}\text { Indoor Air Quality In } \\
\text { Car Parks }\end{array}$ & $\mathbf{0 . 2 5}$ & - & - \\
\hline
\end{tabular}

\begin{tabular}{|c|c|c|c|c|c|}
\hline Criteria Group & Criteria & $\begin{array}{l}\text { Possible } \\
\text { Points }\end{array}$ & Title Criterion & $\begin{array}{l}\text { In Category } \\
\text { Included }\end{array}$ & Score \\
\hline \multirow{5}{*}{$\begin{array}{l}\text { Architectural } \\
\text { and Cultural } \\
\text { Considerations }\end{array}$} & $\begin{array}{l}\text { Cultural Heritage } \\
\text { Integration }\end{array}$ & 0.25 & - & - & 0 \\
\hline & Aesthetic Aspects & 0.25 & - & - & 0 \\
\hline & $\begin{array}{l}\text { Design And Urban } \\
\text { Development }\end{array}$ & 0.25 & - & - & 0 \\
\hline & Monument & 0.25 & - & - & 0 \\
\hline & $\begin{array}{l}\text { Branding And External } \\
\text { Expression }\end{array}$ & 0.25 & - & - & 0 \\
\hline
\end{tabular}




\begin{tabular}{|c|c|c|c|c|c|}
\hline Criteria Group & Criteria & $\begin{array}{l}\text { Possible } \\
\text { Points }\end{array}$ & Title Criterion & $\begin{array}{l}\text { In Category } \\
\text { Included }\end{array}$ & Score \\
\hline \multirow{7}{*}{ 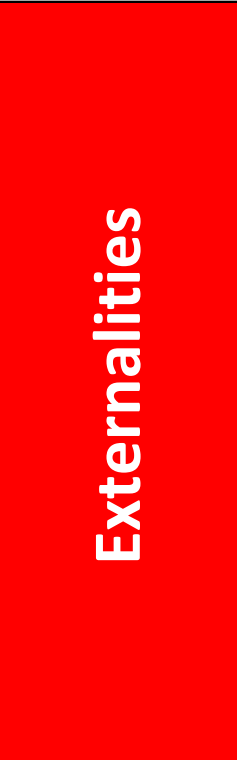 } & $\begin{array}{l}\text { Local Employment } \\
\text { Opportunities / Use Of } \\
\text { Local Services }\end{array}$ & 0.25 & - & - & 0 \\
\hline & $\begin{array}{l}\text { Community Impact } \\
\text { Consultation }\end{array}$ & 0.25 & - & - & 0 \\
\hline & $\begin{array}{l}\text { Responsible And } \\
\text { Ethical Procurement }\end{array}$ & 0.25 & - & - & 0 \\
\hline & Available Services & 0.25 & $\begin{array}{l}\text { Development } \\
\text { Density and } \\
\text { Community } \\
\text { Connectivity }\end{array}$ & $\begin{array}{c}\text { Sustainable } \\
\text { Sites }\end{array}$ & 0.25 \\
\hline & $\begin{array}{l}\text { Social Cost Benefit } \\
\text { Analysis }\end{array}$ & 0.25 & - & - & 0 \\
\hline & $\begin{array}{l}\text { Considerate } \\
\text { Constructors }\end{array}$ & 0.25 & - & - & 0 \\
\hline & Neighborhood & 0.25 & - & - & 0 \\
\hline
\end{tabular}

\begin{tabular}{|c|c|c|c|c|c|}
\hline Criteria Group & Criteria & $\begin{array}{c}\text { Possible } \\
\text { Points }\end{array}$ & Title Criterion & $\begin{array}{l}\text { In Category } \\
\text { Included }\end{array}$ & Score \\
\hline \multirow{3}{*}{$\begin{array}{l}\text { Planning and } \\
\text { Implementation }\end{array}$} & $\begin{array}{l}\text { Choice Of } \\
\text { Construction Process }\end{array}$ & 0.25 & - & - & 0 \\
\hline & $\begin{array}{l}\text { Quality Assurance Of } \\
\text { Construction } \\
\text { Execution }\end{array}$ & 0.25 & - & - & 0 \\
\hline & $\begin{array}{l}\text { Exemplary } \\
\text { Performance }\end{array}$ & 0.25 & - Regional Priority & $\begin{array}{c}\text { Regional } \\
\text { Priority }\end{array}$ & 0.25 \\
\hline
\end{tabular}




\section{BREEAM:}

\begin{tabular}{|c|c|c|c|c|c|}
\hline $\begin{array}{l}\text { Criteria } \\
\text { Group }\end{array}$ & Criteria & $\begin{array}{l}\text { Possible } \\
\text { Points }\end{array}$ & Title Criterion & $\begin{array}{l}\text { In Category } \\
\text { Included }\end{array}$ & Score \\
\hline \multirow{7}{*}{$\frac{80}{20}$} & Total Energy & 1 & $\begin{array}{l}\text { - Construction Site } \\
\text { Impacts - Energy } \\
\text { Consumption }\end{array}$ & Management & \multirow[t]{2}{*}{1} \\
\hline & & & $\begin{array}{l}\text { - Energy } \\
\text { Monitoring }\end{array}$ & Energy & \\
\hline & $\begin{array}{l}\text { Use Of Non-Renewable } \\
\text { Primary Energy }\end{array}$ & 1 & - & - & 0 \\
\hline & $\begin{array}{l}\text { Use Of Renewable } \\
\text { Primary Energy }\end{array}$ & 1 & $\begin{array}{l}\text { - Low and Zero } \\
\text { Carbon } \\
\text { Technologies }\end{array}$ & Energy & 1 \\
\hline & $\begin{array}{l}\text { Use Of Further Energy } \\
\text { Resources }\end{array}$ & 1 & - & - & 0 \\
\hline & $\begin{array}{l}\text { Energy Efficiency of } \\
\text { Building Equipment }\end{array}$ & 1 & $\begin{array}{l}\text { - External Lighting } \\
\text { - Energy Efficient } \\
\text { Cold Storage } \\
\text { - Energy Efficient } \\
\text { Transportation } \\
\text { Systems } \\
\text { - Energy Efficient } \\
\text { Laboratory } \\
\text { Systems } \\
\text { - Energy Efficient } \\
\text { Equipment } \\
\text { - Drying Space }\end{array}$ & Energy & 1 \\
\hline & Embodied Energy & 1 & - Life Cycle Impacts & Materials & 1 \\
\hline
\end{tabular}




\begin{tabular}{|c|c|c|c|c|c|}
\hline $\begin{array}{l}\text { Criteria } \\
\text { Group }\end{array}$ & Criteria & $\begin{array}{l}\text { Possible } \\
\text { Points }\end{array}$ & Title Criterion & $\begin{array}{l}\text { In Category } \\
\text { Included }\end{array}$ & $\begin{array}{c}\text { Scor } \\
\text { e }\end{array}$ \\
\hline \multirow{7}{*}{$\frac{10}{10}$} & Poruclod Pouced & & - Life Cycle Impacts & Materials & \multirow[b]{2}{*}{1} \\
\hline & $\begin{array}{l}\text { Materials And } \\
\text { Components }\end{array}$ & 1 & $\begin{array}{l}\text { - Recycled } \\
\text { Aggregates } \\
\text { - Operational Waste }\end{array}$ & Waste & \\
\hline & & & $\begin{array}{l}\text { - Construction Site } \\
\text { Impact - Timber } \\
\text { Procurement }\end{array}$ & Management & \multirow{3}{*}{1} \\
\hline & $\begin{array}{l}\text { Certified Materials And } \\
\text { Components }\end{array}$ & 1 & $\begin{array}{l}\text { - Life Cycle Impacts } \\
\text { - Responsible }\end{array}$ & & \\
\hline & & & $\begin{array}{l}\text { Sourcing of } \\
\text { Materials } \\
\text { - Insulation }\end{array}$ & Materials & \\
\hline & Risks From Materials & 1 & - & - & 0 \\
\hline & Local / Regional Material & 1 & - & - & 0 \\
\hline
\end{tabular}




\begin{tabular}{|c|c|c|c|c|c|}
\hline $\begin{array}{l}\text { Criteria } \\
\text { Group }\end{array}$ & Criteria & $\begin{array}{l}\text { Possible } \\
\text { Points }\end{array}$ & Title Criterion & $\begin{array}{l}\text { In Category } \\
\text { Included }\end{array}$ & Score \\
\hline \multirow{11}{*}{$\begin{array}{l}1 \\
E \\
E\end{array}$} & & \multirow{4}{*}{1} & $\begin{array}{l}\text { - Construction Site } \\
\text { Impact - Transport } \\
\text { of Construction } \\
\text { Materials and } \\
\text { Waste }\end{array}$ & Management & \multirow{4}{*}{1} \\
\hline & & & $\begin{array}{l}\text { - Impact of } \\
\text { Refrigerants }\end{array}$ & Pollution & \\
\hline & $\begin{array}{l}\text { Greenhouse Gas - Carbon } \\
\text { Dioxide }\left(\mathrm{CO}_{2}\right)\end{array}$ & & $\begin{array}{l}\text { - Reduction of } \mathrm{CO}_{2} \\
\text { Emissions } \\
\text { - Low and Zero } \\
\text { Carbon } \\
\text { Technologies } \\
\text { - Energy Efficient } \\
\text { Cold Storage } \\
\text { - Energy Efficient } \\
\text { Laboratory } \\
\text { Systems }\end{array}$ & Energy & \\
\hline & & & - Life Cycle Impacts & Materials & \\
\hline & $\begin{array}{l}\text { Greenhouse Gas - } \\
\text { Methane }\left(\mathrm{CH}_{4}\right)\end{array}$ & 1 & - & - & 0 \\
\hline & $\begin{array}{l}\text { Greenhouse Gas - Nitrous } \\
\text { Oxide }\left(\mathrm{N}_{2} \mathrm{O}\right)\end{array}$ & 1 & - Nox Emissions & Pollution & 1 \\
\hline & $\begin{array}{l}\text { Greenhouse Gas - } \\
\text { Fluorinated Gases }\end{array}$ & 1 & - & - & 0 \\
\hline & Pollution & 1 & - & - & 0 \\
\hline & Acidification & 1 & - & - & 0 \\
\hline & Ozone Depletion & 1 & - & - & 0 \\
\hline & Eutrophication & 1 & - & - & 0 \\
\hline
\end{tabular}




\begin{tabular}{|c|c|c|c|c|c|}
\hline $\begin{array}{l}\text { Criteria } \\
\text { Group }\end{array}$ & Criteria & $\begin{array}{l}\text { Possible } \\
\text { Points }\end{array}$ & Title Criterion & $\begin{array}{l}\text { In Category } \\
\text { Included }\end{array}$ & Score \\
\hline \multirow{3}{*}{$\frac{80}{0}$} & Green Field / Brown Field & 1 & - Site Selection & $\begin{array}{l}\text { Land Use } \\
\text { and Ecology }\end{array}$ & 1 \\
\hline & $\begin{array}{l}\text { Land Regeneration \& } \\
\text { Development }\end{array}$ & 1 & - & - & 0 \\
\hline & Site Ecology & 1 & $\begin{array}{l}\text { - Ecological Value of } \\
\text { Site and } \\
\text { Protection of } \\
\text { Ecological } \\
\text { Features } \\
\text { - Mitigating } \\
\text { Ecological Impact } \\
\text { - Enhancing Site } \\
\text { Ecology }\end{array}$ & $\begin{array}{l}\text { Land Use } \\
\text { and Ecology }\end{array}$ & 1 \\
\hline \multirow{3}{*}{ 凹 } & $\begin{array}{l}\text { Site Location, Site } \\
\text { Characteristics }\end{array}$ & 1 & - & - & 0 \\
\hline & $\begin{array}{l}\text { Habitat Management } \\
\text { Plan }\end{array}$ & 1 & $\begin{array}{l}\text { - Ecological Value of } \\
\text { Site and } \\
\text { Protection of } \\
\text { Ecological } \\
\text { Features }\end{array}$ & $\begin{array}{l}\text { Land Use } \\
\text { and Ecology }\end{array}$ & 1 \\
\hline & Biodiversity & 1 & $\begin{array}{l}\text { - Long Term Impact } \\
\text { on Biodiversity }\end{array}$ & $\begin{array}{l}\text { Land Use } \\
\text { and Ecology }\end{array}$ & 1 \\
\hline
\end{tabular}




\begin{tabular}{|c|c|c|c|c|c|}
\hline $\begin{array}{l}\text { Criteria } \\
\text { Group }\end{array}$ & Criteria & $\begin{array}{l}\text { Possible } \\
\text { Points }\end{array}$ & Title Criterion & $\begin{array}{l}\text { In Category } \\
\text { Included }\end{array}$ & Score \\
\hline \multirow{9}{*}{$\underset{1}{3}$} & & & $\begin{array}{l}\text { - Construction Site } \\
\text { Impacts - Water } \\
\text { Consumption }\end{array}$ & Management & \\
\hline & Potable Water & 1 & $\begin{array}{l}\text { - Water } \\
\text { Consumption } \\
\text { - Water Monitoring } \\
\text { - Water Leak } \\
\text { Detection and } \\
\text { Prevention }\end{array}$ & Water & 1 \\
\hline & $\begin{array}{l}\text { Grey Water / Waste } \\
\text { Water }\end{array}$ & 1 & - & - & 0 \\
\hline & Storm Water & 1 & - & - & 0 \\
\hline & $\begin{array}{l}\text { Water Efficiency of } \\
\text { Facility \& Appliances }\end{array}$ & 1 & $\begin{array}{l}\text { - Water Efficient } \\
\text { Equipment }\end{array}$ & Water & 1 \\
\hline & Runoff & 1 & $\begin{array}{l}\text { - Surface Water Run } \\
\text { Off }\end{array}$ & Pollution & 1 \\
\hline & Planting & 1 & - & - & 0 \\
\hline & Embodied Water & 1 & - & - & 0 \\
\hline & Water Pollution & 1 & - Water Quality & $\begin{array}{l}\text { Health and } \\
\text { Wellbeing }\end{array}$ & 1 \\
\hline
\end{tabular}

\begin{tabular}{|c|c|c|c|c|c|}
\hline $\begin{array}{l}\text { Criteria } \\
\text { Group }\end{array}$ & Criteria & $\begin{array}{l}\text { Possible } \\
\text { Points }\end{array}$ & Title Criterion & $\begin{array}{l}\text { In Category } \\
\text { Included }\end{array}$ & Score \\
\hline \multirow{5}{*}{\begin{tabular}{l}
0 \\
\multirow{1}{*}{} \\
\multirow{2}{*}{}
\end{tabular}} & Hazardous Waste & 1 & - & - & 0 \\
\hline & Non-Hazardous Waste & 1 & - & - & 0 \\
\hline & Organic Waste & 1 & - & - & 0 \\
\hline & Inorganic Waste & 1 & - & - & 0 \\
\hline & Radioactive Waste & 1 & - & - & 0 \\
\hline
\end{tabular}




\begin{tabular}{|c|c|c|c|c|c|}
\hline $\begin{array}{l}\text { Criteria } \\
\text { Group }\end{array}$ & Criteria & $\begin{array}{l}\text { Possible } \\
\text { Points }\end{array}$ & Title Criterion & $\begin{array}{l}\text { In Category } \\
\text { Included }\end{array}$ & Score \\
\hline \multirow{3}{*}{$\begin{array}{l}n \\
0 \\
0 \\
0\end{array}$} & Initial Costs & 1 & \multirow{4}{*}{$\begin{array}{l}\text { - Life Cycle Cost and } \\
\text { Service Life } \\
\text { Planning }\end{array}$} & \multirow{4}{*}{ Management } & 1 \\
\hline & $\begin{array}{l}\text { Costs For Operation, } \\
\text { Maintenance And Repair }\end{array}$ & 1 & & & 1 \\
\hline & Replacement Costs & 1 & & & 1 \\
\hline (a) & $\begin{array}{l}\text { Risk \& Value } \\
\text { Management }\end{array}$ & 1 & & & 1 \\
\hline & Function Analysis & 1 & - & - & 0 \\
\hline 4 & Payback Time & 1 & $\begin{array}{l}\text { - Low and Zero } \\
\text { Carbon } \\
\text { Technologies - } \\
\text { Feasibility Study / } \\
\text { Renewable Supply } \\
\text { Contract }\end{array}$ & Energy & 0.5 \\
\hline
\end{tabular}

\begin{tabular}{|c|c|c|c|c|c|}
\hline $\begin{array}{l}\text { Criteria } \\
\text { Group }\end{array}$ & Criteria & $\begin{array}{l}\text { Possible } \\
\text { Points }\end{array}$ & Title Criterion & $\begin{array}{l}\text { In Category } \\
\text { Included }\end{array}$ & Score \\
\hline \multirow{7}{*}{ 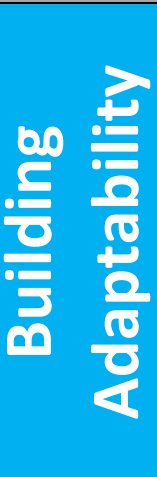 } & Demand Of Space & 1 & - & - & 0 \\
\hline & Area Efficiency & 1 & - & - & 0 \\
\hline & Capacity & 1 & - & - & 0 \\
\hline & Occupancy & 1 & - & - & 0 \\
\hline & Longevity & 1 & $\begin{array}{l}\text { - Designing for } \\
\text { Robustness }\end{array}$ & Materials & 1 \\
\hline & $\begin{array}{l}\text { Adaptability And } \\
\text { Versatility }\end{array}$ & 1 & - & - & 0 \\
\hline & $\begin{array}{l}\text { Demolition / Reuse / } \\
\text { Recycling }\end{array}$ & 1 & - & - & 0 \\
\hline
\end{tabular}




\begin{tabular}{|c|c|c|c|c|c|}
\hline $\begin{array}{l}\text { Criteria } \\
\text { Group }\end{array}$ & Criteria & $\begin{array}{l}\text { Possible } \\
\text { Points }\end{array}$ & Title Criterion & $\begin{array}{l}\text { In Category } \\
\text { Included }\end{array}$ & Score \\
\hline \multirow{18}{*}{ 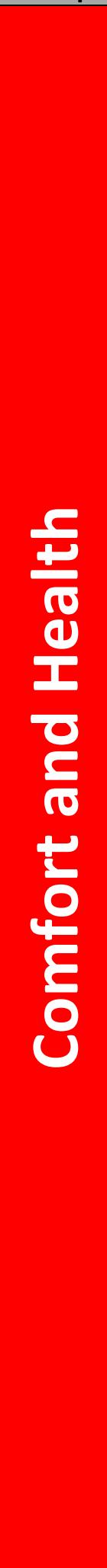 } & Daylighting & 1 & $\begin{array}{l}\text { - Visual Comfort - } \\
\text { Daylighting }\end{array}$ & $\begin{array}{l}\text { Health and } \\
\text { Wellbeing }\end{array}$ & 1 \\
\hline & Illumination & 1 & $\begin{array}{l}\text { - Visual Comfort - } \\
\text { Internal and } \\
\text { External Lighting }\end{array}$ & $\begin{array}{l}\text { Health and } \\
\text { Wellbeing }\end{array}$ & 1 \\
\hline & $\begin{array}{l}\text { Lighting Zones And } \\
\text { Control: Lighting For } \\
\text { Suitable Tasks In Lux }\end{array}$ & 1 & - & - & 0 \\
\hline & 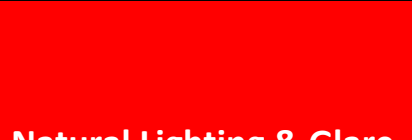 & 1 & $\begin{array}{l}\text { - Visual Comfort - } \\
\text { Glare Control and } \\
\text { View Out }\end{array}$ & $\begin{array}{l}\text { Health and } \\
\text { Wellbeing }\end{array}$ & \\
\hline & Natural Lignting \& Glare & 1 & $\begin{array}{l}\text { - Reduction of Night } \\
\text { Time Light } \\
\text { Pollution }\end{array}$ & Pollution & 1 \\
\hline & Thermal Comfort & 1 & - Thermal Comfort & $\begin{array}{l}\text { Health and } \\
\text { Wellbeing }\end{array}$ & 1 \\
\hline & $\begin{array}{l}\text { Air Temperature And } \\
\text { Relative Humidity }\end{array}$ & 1 & - & - & 0 \\
\hline & $\begin{array}{l}\text { Summer / Winter } \\
\text { Conditions }\end{array}$ & 1 & - & - & 0 \\
\hline & Thermal Zoning & 1 & - & - & 0 \\
\hline & $\begin{array}{l}\text { Noise From Building And } \\
\text { Site }\end{array}$ & 1 & $\begin{array}{l}\text { - Acoustic } \\
\text { Performance }\end{array}$ & $\begin{array}{l}\text { Health and } \\
\text { Wellbeing }\end{array}$ & 1 \\
\hline & Background Noise Level & 1 & \multirow{2}{*}{ - Noise Attenuation } & \multirow{2}{*}{ Pollution } & 1 \\
\hline & Reverberation Time & 1 & & & 1 \\
\hline & $\begin{array}{l}\text { Indoor Air Pollutants } \\
\text { Concentration }\end{array}$ & 1 & $\begin{array}{l}\text { - Indoor Air Quality } \\
\text { - Minimizing } \\
\text { Sources of Air } \\
\text { Pollution } \\
\text { - Indoor Air Quality } \\
\text { - Laboratory Fume } \\
\text { Cupboard and } \\
\text { Containment } \\
\text { Areas }\end{array}$ & $\begin{array}{l}\text { Health and } \\
\text { Wellbeing }\end{array}$ & 1 \\
\hline & Ventilation Conditions & 1 & $\begin{array}{l}\text { - Indoor Air Quality } \\
\text { - Potential for } \\
\text { Natural Ventilation }\end{array}$ & $\begin{array}{l}\text { Health and } \\
\text { Wellbeing }\end{array}$ & 1 \\
\hline & Mold Growth Risk & 1 & - & - & 0 \\
\hline & $\begin{array}{l}\mathrm{CO}_{2} \text {, Formaldehyde and } \\
\text { Nitrogen Oxide } \\
\text { Concentration }\end{array}$ & 1 & - & - & 0 \\
\hline & Access To View & 1 & - & - & 0 \\
\hline & Privacy & 1 & & & 0 \\
\hline
\end{tabular}




\begin{tabular}{|l|l|c|c|c|c|}
\hline & Feelings And Sensations & $\mathbf{1}$ & $\begin{array}{c}\text { - Visual Comfort - } \\
\text { Visual Arts }\end{array}$ & $\begin{array}{c}\text { Health and } \\
\text { Wellbeing }\end{array}$ & 1 \\
\cline { 2 - 6 } & Recreation & $\mathbf{1}$ & - & - & 0 \\
\hline $\begin{array}{l}\text { Human Interactions / } \\
\text { Relationships }\end{array}$ & $\mathbf{1}$ & - & - & 0 \\
\cline { 2 - 5 } Interior Qualities & $\mathbf{1}$ & - & - & 0 \\
\hline
\end{tabular}

\begin{tabular}{|c|c|c|c|c|c|}
\hline $\begin{array}{l}\text { Criteria } \\
\text { Group }\end{array}$ & Criteria & $\begin{array}{c}\text { Possible } \\
\text { Points }\end{array}$ & Title Criterion & $\begin{array}{l}\text { In Category } \\
\text { Included }\end{array}$ & Score \\
\hline \multirow{5}{*}{ 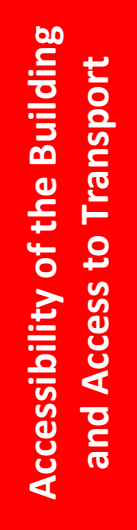 } & $\begin{array}{l}\text { Public \& Public } \\
\text { Transport Accessibility }\end{array}$ & 1 & $\begin{array}{l}\text { - Public Transport } \\
\text { Accessibility }\end{array}$ & Transport & 1 \\
\hline & $\begin{array}{l}\text { Barrier-Free } \\
\text { Accessibility }\end{array}$ & 1 & $\begin{array}{l}\text { - Stakeholder } \\
\text { Participation - } \\
\text { Inclusive and } \\
\text { Accessible Design }\end{array}$ & Management & 1 \\
\hline & Bicycle Comfort & 1 & - Cyclist Facilities & Transport & 1 \\
\hline & Pedestrian Comfort & 1 & - & - & 0 \\
\hline & Car Parking Capacity & 1 & $\begin{array}{l}\text { - Maximum Car } \\
\text { Parking Capacity }\end{array}$ & Transport & 1 \\
\hline
\end{tabular}

\begin{tabular}{|c|c|c|c|c|c|}
\hline $\begin{array}{l}\text { Criteria } \\
\text { Group }\end{array}$ & Criteria & $\begin{array}{l}\text { Possible } \\
\text { Points }\end{array}$ & Title Criterion & $\begin{array}{l}\text { In Category } \\
\text { Included }\end{array}$ & Score \\
\hline \multirow{7}{*}{ 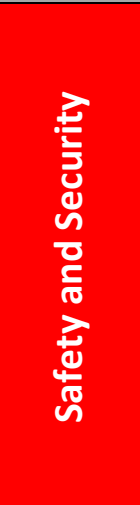 } & Safety Assessment & 1 & \multirow{2}{*}{$\begin{array}{l}\text { - Safety and Security } \\
\text { - Safety Access }\end{array}$} & \multirow{2}{*}{$\begin{array}{l}\text { Health and } \\
\text { Wellbeing }\end{array}$} & 1 \\
\hline & Safety Management & 1 & & & 1 \\
\hline & Site And Building & 1 & $\begin{array}{l}\text { - Safety and Security } \\
\text { - Security of Site } \\
\text { and Building }\end{array}$ & $\begin{array}{l}\text { Health and } \\
\text { Wellbeing }\end{array}$ & 1 \\
\hline & Combustion Sources & 1 & - & - & 0 \\
\hline & $\begin{array}{l}\text { Resistance - Storm, } \\
\text { High Water }\end{array}$ & 1 & - & - & 0 \\
\hline & Resistance - Hail & 1 & - & - & 0 \\
\hline & Resistance - Earthquake & 1 & - & - & 0 \\
\hline
\end{tabular}




\begin{tabular}{|c|c|c|c|c|c|}
\hline $\begin{array}{l}\text { Criteria } \\
\text { Group }\end{array}$ & Criteria & $\begin{array}{l}\text { Possible } \\
\text { Points }\end{array}$ & Title Criterion & $\begin{array}{l}\text { In Category } \\
\text { Included }\end{array}$ & Score \\
\hline \multirow{4}{*}{ 0 붑 } & Infrastructure & 0.5 & $\begin{array}{l}\text { - Proximity to } \\
\text { Amenities }\end{array}$ & Transport & 0.5 \\
\hline & Heat Island Effect & 0.5 & - & - & 0 \\
\hline & Landscape Inputs & 0.5 & $\begin{array}{l}\text { - Hard Landscaping } \\
\text { and Boundary } \\
\text { Protection }\end{array}$ & Materials & 0.5 \\
\hline & Risk At The Site & 0.5 & - & - & 0 \\
\hline
\end{tabular}

\begin{tabular}{|c|c|c|c|c|c|}
\hline $\begin{array}{l}\text { Criteria } \\
\text { Group }\end{array}$ & Criteria & $\begin{array}{l}\text { Possible } \\
\text { Points }\end{array}$ & Title Criterion & $\begin{array}{l}\text { In Category } \\
\text { Included }\end{array}$ & Score \\
\hline \multirow{2}{*}{ 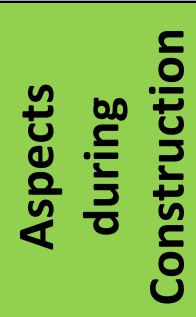 } & Construction Waste & 0.5 & $\begin{array}{l}\text { - Construction } \\
\text { Waste } \\
\text { Management }\end{array}$ & Waste & 0.5 \\
\hline & $\begin{array}{l}\text { Construction Indoor Air } \\
\text { Quality }\end{array}$ & 0.5 & $\begin{array}{l}\text { - Construction Site } \\
\text { Impact - } \\
\text { Construction Site } \\
\text { Management }\end{array}$ & Management & 0.5 \\
\hline
\end{tabular}

\begin{tabular}{|c|c|c|c|c|c|}
\hline $\begin{array}{l}\text { Criteria } \\
\text { Group }\end{array}$ & Criteria & $\begin{array}{l}\text { Possible } \\
\text { Points }\end{array}$ & Title Criterion & $\begin{array}{l}\text { In Category } \\
\text { Included }\end{array}$ & Score \\
\hline \multirow{4}{*}{ 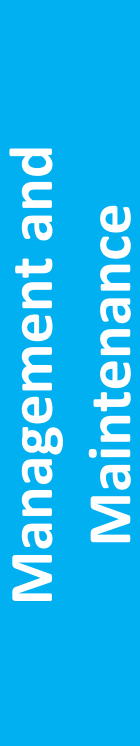 } & $\begin{array}{l}\text { Building User Guide, } \\
\text { Awareness \& Education }\end{array}$ & 0.5 & $\begin{array}{l}\text { - Sustainable } \\
\text { Procurement - } \\
\text { Project Brief and } \\
\text { Design } \\
\text { - Stakeholder } \\
\text { Participation - } \\
\text { Building User } \\
\text { Information }\end{array}$ & Management & 0.5 \\
\hline & $\begin{array}{l}\text { Establishing } \\
\text { Preconditions For An } \\
\text { Optimized Use And } \\
\text { Operation }\end{array}$ & 0.5 & $\begin{array}{l}\text { - Speculative Floor } \\
\text { and Ceiling } \\
\text { Finishes }\end{array}$ & Waste & 0.25 \\
\hline & $\begin{array}{l}\text { Maintainability And } \\
\text { Operation Comfort }\end{array}$ & 0.5 & - & - & 0 \\
\hline & $\begin{array}{l}\text { Intelligence And } \\
\text { Controllability }\end{array}$ & 0.5 & - & - & 0 \\
\hline
\end{tabular}




\begin{tabular}{|c|c|c|c|c|c|}
\hline $\begin{array}{l}\text { Criteria } \\
\text { Group }\end{array}$ & Criteria & $\begin{array}{l}\text { Possible } \\
\text { Points }\end{array}$ & Title Criterion & $\begin{array}{l}\text { In Category } \\
\text { Included }\end{array}$ & Score \\
\hline \multirow{5}{*}{ 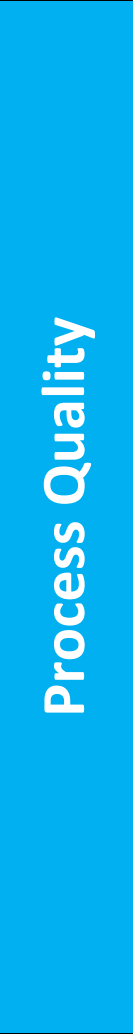 } & $\begin{array}{l}\text { Integral Planning, } \\
\text { Integrated Design }\end{array}$ & 0.5 & $\begin{array}{l}\text { - Sustainable } \\
\text { Procurement - } \\
\text { Project Brief and } \\
\text { Design } \\
\text { - Stakeholder } \\
\text { Participation - } \\
\text { Consultation }\end{array}$ & Management & 0.5 \\
\hline & $\begin{array}{l}\text { Optimization And } \\
\text { Complexity Of The } \\
\text { Planning Approach }\end{array}$ & 0.5 & - & - & 0 \\
\hline & $\begin{array}{l}\text { Quality Of Project's } \\
\text { Preparation }\end{array}$ & 0.5 & - & - & 0 \\
\hline & $\begin{array}{l}\text { Quality Of The Executing } \\
\text { Contractors / } \\
\text { Prequalification }\end{array}$ & 0.5 & $\begin{array}{l}\text { - Responsible } \\
\text { Construction } \\
\text { Practices } \\
\end{array}$ & Management & 0.5 \\
\hline & $\begin{array}{l}\text { Controlled } \\
\text { Commissioning }\end{array}$ & 0.5 & $\begin{array}{l}\text { - Sustainable } \\
\text { Procurement - } \\
\text { Construction and } \\
\text { Handover } \\
\text { - Sustainable } \\
\text { Procurement - } \\
\text { Aftercare } \\
\end{array}$ & Management & 0.5 \\
\hline
\end{tabular}

\begin{tabular}{|c|c|c|c|c|c|}
\hline $\begin{array}{c}\text { Criteria } \\
\text { Group }\end{array}$ & Criteria & $\begin{array}{c}\text { Possible } \\
\text { Points }\end{array}$ & Title Criterion & $\begin{array}{c}\text { In Category } \\
\text { Included }\end{array}$ & Score \\
\hline Innovation & $\begin{array}{l}\text { Innovations, Innovative } \\
\text { Strategies \& Technologies }\end{array}$ & $\mathbf{0 . 5}$ & - Innovation & Innovation & 0.5 \\
\hline
\end{tabular}

\begin{tabular}{|c|c|c|c|c|c|}
\hline $\begin{array}{c}\text { Criteria } \\
\text { Group }\end{array}$ & \multicolumn{1}{|c|}{ Criteria } & $\begin{array}{c}\text { Possible } \\
\text { Points }\end{array}$ & Title Criterion & $\begin{array}{c}\text { In Category } \\
\text { Included }\end{array}$ & Score \\
\hline Usability & $\begin{array}{l}\text { Communications And } \\
\text { Mobility }\end{array}$ & 0.5 & - & - & 0 \\
\hline
\end{tabular}




\begin{tabular}{|c|l|c|c|c|c|}
\hline Criteria Group & \multicolumn{1}{|c|}{ Criteria } & $\begin{array}{c}\text { Possible } \\
\text { Points }\end{array}$ & Title Criterion & $\begin{array}{c}\text { In Category } \\
\text { Included }\end{array}$ & Score \\
\hline \multirow{2}{*}{$\begin{array}{c}\text { Further } \\
\text { Environmental } \\
\text { Criteria }\end{array}$} & Neighboring Buildings & $\mathbf{0 . 2 5}$ & - & - & 0 \\
\cline { 2 - 6 } & $\begin{array}{l}\text { Modular and } \\
\text { Standardized Materials } \\
\text { And Components }\end{array}$ & $\mathbf{0 . 2 5}$ & - & - & 0 \\
\cline { 2 - 6 } & Service Life & $\mathbf{0 . 2 5}$ & - & - & 0 \\
\hline
\end{tabular}

\begin{tabular}{|c|c|c|c|c|c|}
\hline Criteria Group & Criteria & $\begin{array}{l}\text { Possible } \\
\text { Points }\end{array}$ & Title Criterion & $\begin{array}{l}\text { In Category } \\
\text { Included }\end{array}$ & Score \\
\hline \multirow{2}{*}{$\begin{array}{l}\text { Further Indoor } \\
\text { Environmental } \\
\text { Criteria }\end{array}$} & $\begin{array}{l}\text { Electromagnetic } \\
\text { Emissions }\end{array}$ & 0.25 & - & - & 0 \\
\hline & $\begin{array}{l}\text { Indoor Air Quality In } \\
\text { Car Parks }\end{array}$ & 0.25 & - & - & 0 \\
\hline
\end{tabular}

\begin{tabular}{|c|c|c|c|c|c|}
\hline Criteria Group & Criteria & $\begin{array}{l}\text { Possible } \\
\text { Points }\end{array}$ & Title Criterion & $\begin{array}{l}\text { In Category } \\
\text { Included }\end{array}$ & Score \\
\hline \multirow{5}{*}{$\begin{array}{l}\text { Architectural } \\
\text { and Cultural } \\
\text { Considerations }\end{array}$} & $\begin{array}{l}\text { Cultural Heritage } \\
\text { Integration }\end{array}$ & 0.25 & - & - & 0 \\
\hline & Aesthetic Aspects & 0.25 & - & - & 0 \\
\hline & $\begin{array}{l}\text { Design And Urban } \\
\text { Development }\end{array}$ & 0.25 & - & - & 0 \\
\hline & Monument & 0.25 & - & - & 0 \\
\hline & $\begin{array}{l}\text { Branding And External } \\
\text { Expression }\end{array}$ & 0.25 & - & - & 0 \\
\hline
\end{tabular}




\begin{tabular}{|c|l|c|c|c|c|}
\hline Criteria Group & \multicolumn{1}{|c|}{ Criteria } & $\begin{array}{c}\text { Possible } \\
\text { Points }\end{array}$ & Title Criterion & $\begin{array}{c}\text { In Category } \\
\text { Included }\end{array}$ & Score \\
\hline \multirow{2}{*}{} & $\begin{array}{l}\text { Local Employment } \\
\text { Opportunities / Use Of } \\
\text { Local Services }\end{array}$ & $\mathbf{0 . 2 5}$ & - & 0 \\
\cline { 2 - 6 } & $\begin{array}{l}\text { Community Impact } \\
\text { Consultation }\end{array}$ & $\mathbf{0 . 2 5}$ & - & 0 \\
\cline { 2 - 6 } & $\begin{array}{l}\text { Responsible And } \\
\text { Ethical Procurement }\end{array}$ & $\mathbf{0 . 2 5}$ & - & - & 0 \\
\cline { 2 - 7 } & Available Services & $\mathbf{0 . 2 5}$ & - & - & 0 \\
\cline { 2 - 7 } & $\begin{array}{l}\text { Social Cost Benefit } \\
\text { Analysis }\end{array}$ & $\mathbf{0 . 2 5}$ & - & - & 0 \\
\cline { 2 - 6 } & $\begin{array}{l}\text { Considerate } \\
\text { Constructors }\end{array}$ & $\mathbf{0 . 2 5}$ & - & - & 0 \\
\cline { 2 - 6 } & Neighborhood & $\mathbf{0 . 2 5}$ & - & - & 0 \\
\hline
\end{tabular}

\begin{tabular}{|c|c|c|c|c|c|}
\hline Criteria Group & \multicolumn{1}{|c|}{ Criteria } & $\begin{array}{c}\text { Possible } \\
\text { Points }\end{array}$ & \multicolumn{1}{|c|}{ Title Criterion } & $\begin{array}{c}\text { In Category } \\
\text { Included }\end{array}$ & Score \\
\hline \multirow{2}{*}{$\begin{array}{c}\text { Planning and } \\
\text { Implementation }\end{array}$} & $\begin{array}{l}\text { Choice Of } \\
\text { Construction Process } \\
\text { Participation - }\end{array}$ & $\mathbf{0 . 2 5}$ & $\begin{array}{l}\text { Post Occupancy } \\
\text { Evaluation and } \\
\text { Information } \\
\text { Dissemination }\end{array}$ & Management & 0.25 \\
\cline { 2 - 7 } & $\begin{array}{l}\text { Quality Assurance Of } \\
\text { Construction } \\
\text { Execution }\end{array}$ & $\begin{array}{l}\text { - Sustainable } \\
\text { Procurement - } \\
\text { Construction and } \\
\text { Handover }\end{array}$ & Management & 0.25 \\
\cline { 2 - 7 } & $\begin{array}{l}\text { Exemplary } \\
\text { Performance }\end{array}$ & $\mathbf{0 . 2 5}$ & - & - & 0 \\
\hline
\end{tabular}


DGNB:

\begin{tabular}{|c|c|c|c|c|c|}
\hline $\begin{array}{l}\text { Criteria } \\
\text { Group }\end{array}$ & Criteria & $\begin{array}{c}\text { Possible } \\
\text { Points }\end{array}$ & Title Criterion & $\begin{array}{c}\text { In Category } \\
\text { Included }\end{array}$ & Score \\
\hline \multirow{7}{*}{$\begin{array}{l}00 \\
\frac{1}{2} \\
\dot{E}\end{array}$} & & & $\begin{array}{l}\text { - Life Cycle } \\
\text { Assessment of } \\
\text { Primary Energy }\end{array}$ & $\begin{array}{l}\text { Resources } \\
\text { and Waste }\end{array}$ & \\
\hline & Consumption & 1 & $\begin{array}{l}\text { - Quality of the } \\
\text { Building Envelope } \\
\text { With Regard to } \\
\text { Heat and Humidity }\end{array}$ & $\begin{array}{l}\text { Technical } \\
\text { Quality }\end{array}$ & 1 \\
\hline & $\begin{array}{l}\text { Use Of Non-Renewable } \\
\text { Primary Energy }\end{array}$ & 1 & \multirow{2}{*}{$\begin{array}{l}\text { - Life Cycle } \\
\text { Assessment of } \\
\text { Primary Energy }\end{array}$} & \multirow{2}{*}{$\begin{array}{l}\text { Resources } \\
\text { and Waste }\end{array}$} & 1 \\
\hline & $\begin{array}{l}\text { Use Of Renewable } \\
\text { Primary Energy }\end{array}$ & 1 & & & 1 \\
\hline & $\begin{array}{l}\text { Use Of Further Energy } \\
\text { Resources }\end{array}$ & 1 & - & - & 0 \\
\hline & $\begin{array}{l}\text { Energy Efficiency of } \\
\text { Building Equipment }\end{array}$ & 1 & - & - & 0 \\
\hline & Embodied Energy & 1 & - & - & 0 \\
\hline
\end{tabular}

\begin{tabular}{|c|c|c|c|c|c|}
\hline $\begin{array}{c}\text { Criteria } \\
\text { Group }\end{array}$ & Criteria & $\begin{array}{l}\text { Possible } \\
\text { Points }\end{array}$ & Title Criterion & $\begin{array}{c}\text { In Category } \\
\text { Included }\end{array}$ & $\begin{array}{c}\text { Scor } \\
\text { e }\end{array}$ \\
\hline \multirow{4}{*}{$\frac{10}{10}$} & $\begin{array}{l}\text { Recycled, Reused } \\
\text { Materials And } \\
\text { Components }\end{array}$ & 1 & - & - & 0 \\
\hline & $\begin{array}{l}\text { Certified Materials And } \\
\text { Components }\end{array}$ & 1 & $\begin{array}{l}\text { - Risk for the Local } \\
\text { Environment } \\
\text { - Sustainable } \\
\text { Material } \\
\text { Extraction }\end{array}$ & $\begin{array}{l}\text { Global and } \\
\text { Local } \\
\text { Environment }\end{array}$ & 1 \\
\hline & Risks From Materials & 1 & - & - & 0 \\
\hline & Local / Regional Material & 1 & - & - & 0 \\
\hline
\end{tabular}




\begin{tabular}{|c|c|c|c|c|c|}
\hline $\begin{array}{l}\text { Criteria } \\
\text { Group }\end{array}$ & Criteria & $\begin{array}{l}\text { Possible } \\
\text { Points }\end{array}$ & Title Criterion & $\begin{array}{l}\text { In Category } \\
\text { Included }\end{array}$ & Score \\
\hline \multirow[t]{9}{*}{ Q } & $\begin{array}{l}\text { Greenhouse Gas - Carbon } \\
\text { Dioxide }\left(\mathrm{CO}_{2}\right)\end{array}$ & 1 & $\begin{array}{l}\text { - Life Cycle } \\
\text { Assessment of } \\
\text { Emission Caused } \\
\text { Environmental } \\
\text { Impacts }\end{array}$ & $\begin{array}{l}\text { Global and } \\
\text { Local } \\
\text { Environment }\end{array}$ & \multirow[t]{2}{*}{1} \\
\hline & & & - Roof Design & $\begin{array}{l}\text { Health and } \\
\text { Wellbeing }\end{array}$ & \\
\hline & $\begin{array}{l}\text { Greenhouse Gas - } \\
\text { Methane }\left(\mathrm{CH}_{4}\right)\end{array}$ & 1 & - & - & 0 \\
\hline & $\begin{array}{l}\text { Greenhouse Gas - Nitrous } \\
\text { Oxide }\left(\mathrm{N}_{2} \mathrm{O}\right)\end{array}$ & 1 & - & - & 0 \\
\hline & $\begin{array}{l}\text { Greenhouse Gas - } \\
\text { Fluorinated Gases }\end{array}$ & 1 & - & - & 0 \\
\hline & Pollution & 1 & - & - & 0 \\
\hline & Acidification & 1 & \multirow{3}{*}{$\begin{array}{l}\text { - Life Cycle } \\
\text { Assessment of } \\
\text { Emission Caused } \\
\text { Environmental } \\
\text { Impacts }\end{array}$} & \multirow{3}{*}{$\begin{array}{c}\text { Global and } \\
\text { Local } \\
\text { Environment }\end{array}$} & 1 \\
\hline & Ozone Depletion & 1 & & & 1 \\
\hline & Eutrophication & 1 & & & 1 \\
\hline
\end{tabular}

\begin{tabular}{|c|c|c|c|c|c|}
\hline $\begin{array}{c}\text { Criteria } \\
\text { Group }\end{array}$ & Criteria & $\begin{array}{c}\text { Possible } \\
\text { Points }\end{array}$ & Title Criterion & $\begin{array}{l}\text { In Category } \\
\text { Included }\end{array}$ & Score \\
\hline & Green Field / Brown Field & 1 & \multirow[t]{2}{*}{ - Land Use } & \multirow[b]{2}{*}{$\begin{array}{l}\text { Resources } \\
\text { and Waste }\end{array}$} & 1 \\
\hline & $\begin{array}{l}\text { Land Regeneration \& } \\
\text { Development }\end{array}$ & 1 & & & 1 \\
\hline & Site Ecology & 1 & - & - & 0 \\
\hline \multirow[t]{3}{*}{ (1) } & $\begin{array}{l}\text { Site Location, Site } \\
\text { Characteristics }\end{array}$ & 1 & $\begin{array}{l}\text { - Micro } \\
\text { Environment } \\
\text { - Image and } \\
\text { Conditions of Site } \\
\text { and Neighborhood }\end{array}$ & $\begin{array}{l}\text { Quality of } \\
\text { Location }\end{array}$ & 1 \\
\hline & $\begin{array}{l}\text { Habitat Management } \\
\text { Plan }\end{array}$ & 1 & - & - & 0 \\
\hline & Biodiversity & 1 & - & - & 0 \\
\hline
\end{tabular}




\begin{tabular}{|c|c|c|c|c|c|}
\hline $\begin{array}{l}\text { Criteria } \\
\text { Group }\end{array}$ & Criteria & $\begin{array}{l}\text { Possible } \\
\text { Points }\end{array}$ & Title Criterion & $\begin{array}{l}\text { In Category } \\
\text { Included }\end{array}$ & Score \\
\hline \multirow{8}{*}{$\begin{array}{l}\mathbf{1} \\
\sum \\
\dot{3}\end{array}$} & Potable Water & 1 & \multirow{2}{*}{$\begin{array}{l}\text { - Demand of } \\
\text { Drinking Water and } \\
\text { Volume of Waste } \\
\text { Water }\end{array}$} & \multirow{2}{*}{$\begin{array}{c}\text { Resources and } \\
\text { Waste }\end{array}$} & 1 \\
\hline & $\begin{array}{l}\text { Grey Water / Waste } \\
\text { Water }\end{array}$ & 1 & & & 1 \\
\hline & Storm Water & 1 & - & - & 0 \\
\hline & $\begin{array}{l}\text { Water Efficiency of } \\
\text { Facility \& Appliances }\end{array}$ & 1 & - & - & 0 \\
\hline & Runoff & 1 & - & - & 0 \\
\hline & Planting & 1 & - & - & 0 \\
\hline & Embodied Water & 1 & - & - & 0 \\
\hline & Water Pollution & 1 & - & - & 0 \\
\hline
\end{tabular}

\begin{tabular}{|c|c|c|c|c|c|}
\hline $\begin{array}{l}\text { Criteria } \\
\text { Group }\end{array}$ & Criteria & $\begin{array}{l}\text { Possible } \\
\text { Points }\end{array}$ & Title Criterion & $\begin{array}{l}\text { In Category } \\
\text { Included }\end{array}$ & Score \\
\hline \multirow{5}{*}{ 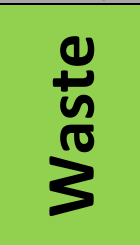 } & Hazardous Waste & 1 & - & - & 0 \\
\hline & Non-Hazardous Waste & 1 & - & - & 0 \\
\hline & Organic Waste & 1 & - & - & 0 \\
\hline & Inorganic Waste & 1 & - & - & 0 \\
\hline & Radioactive Waste & 1 & - & - & 0 \\
\hline
\end{tabular}

\begin{tabular}{|c|c|c|c|c|c|}
\hline $\begin{array}{l}\text { Criteria } \\
\text { Group }\end{array}$ & Criteria & $\begin{array}{c}\text { Possible } \\
\text { Points }\end{array}$ & Title Criterion & $\begin{array}{l}\text { In Category } \\
\text { Included }\end{array}$ & Score \\
\hline \multirow{6}{*}{$\begin{array}{l}n \\
0 \\
0\end{array}$} & Initial Costs & 1 & \multirow{3}{*}{$\begin{array}{l}\text { - Building Related } \\
\text { Life Cycle Costs }\end{array}$} & \multirow{3}{*}{$\begin{array}{l}\text { Life Cycle } \\
\text { Costs }\end{array}$} & 1 \\
\hline & $\begin{array}{l}\text { Costs For Operation, } \\
\text { Maintenance And Repair }\end{array}$ & 1 & & & 1 \\
\hline & Replacement Costs & 1 & & & 1 \\
\hline & $\begin{array}{l}\text { Risk \& Value } \\
\text { Management }\end{array}$ & 1 & $\begin{array}{r}\text { - Flexibility and } \\
\text { Convertibility }\end{array}$ & \multirow{2}{*}{$\begin{array}{l}\text { Progress of } \\
\text { Value }\end{array}$} & 1 \\
\hline & Function Analysis & 1 & - Marketability & & 1 \\
\hline & Payback Time & 1 & - & - & 0 \\
\hline
\end{tabular}




\begin{tabular}{|c|c|c|c|c|c|}
\hline $\begin{array}{l}\text { Criteria } \\
\text { Group }\end{array}$ & Criteria & $\begin{array}{l}\text { Possible } \\
\text { Points }\end{array}$ & Title Criterion & $\begin{array}{l}\text { In Category } \\
\text { Included }\end{array}$ & Score \\
\hline \multirow{7}{*}{ 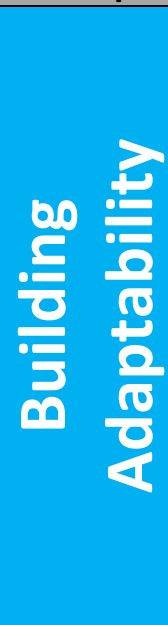 } & Demand Of Space & 1 & - & - & 0 \\
\hline & Area Efficiency & 1 & $\begin{array}{l}\text { - Quality of Floor } \\
\text { Plan }\end{array}$ & Design & 1 \\
\hline & Capacity & 1 & - & - & 0 \\
\hline & Occupancy & 1 & - & - & 0 \\
\hline & Longevity & 1 & - & - & 0 \\
\hline & $\begin{array}{l}\text { Adaptability And } \\
\text { Versatility }\end{array}$ & 1 & $\begin{array}{l}\text { - Flexibility and } \\
\text { Convertibility } \\
\text { - Adaptability of } \\
\text { Technical Systems }\end{array}$ & $\begin{array}{c}\text { Progress of } \\
\text { Value }\end{array}$ & 1 \\
\hline & $\begin{array}{l}\text { Demolition / Reuse / } \\
\text { Recycling }\end{array}$ & 1 & $\begin{array}{l}\text { - Ease of } \\
\text { Dismantling and } \\
\text { Disassembly }\end{array}$ & $\begin{array}{l}\text { Technical } \\
\text { Quality }\end{array}$ & 1 \\
\hline
\end{tabular}




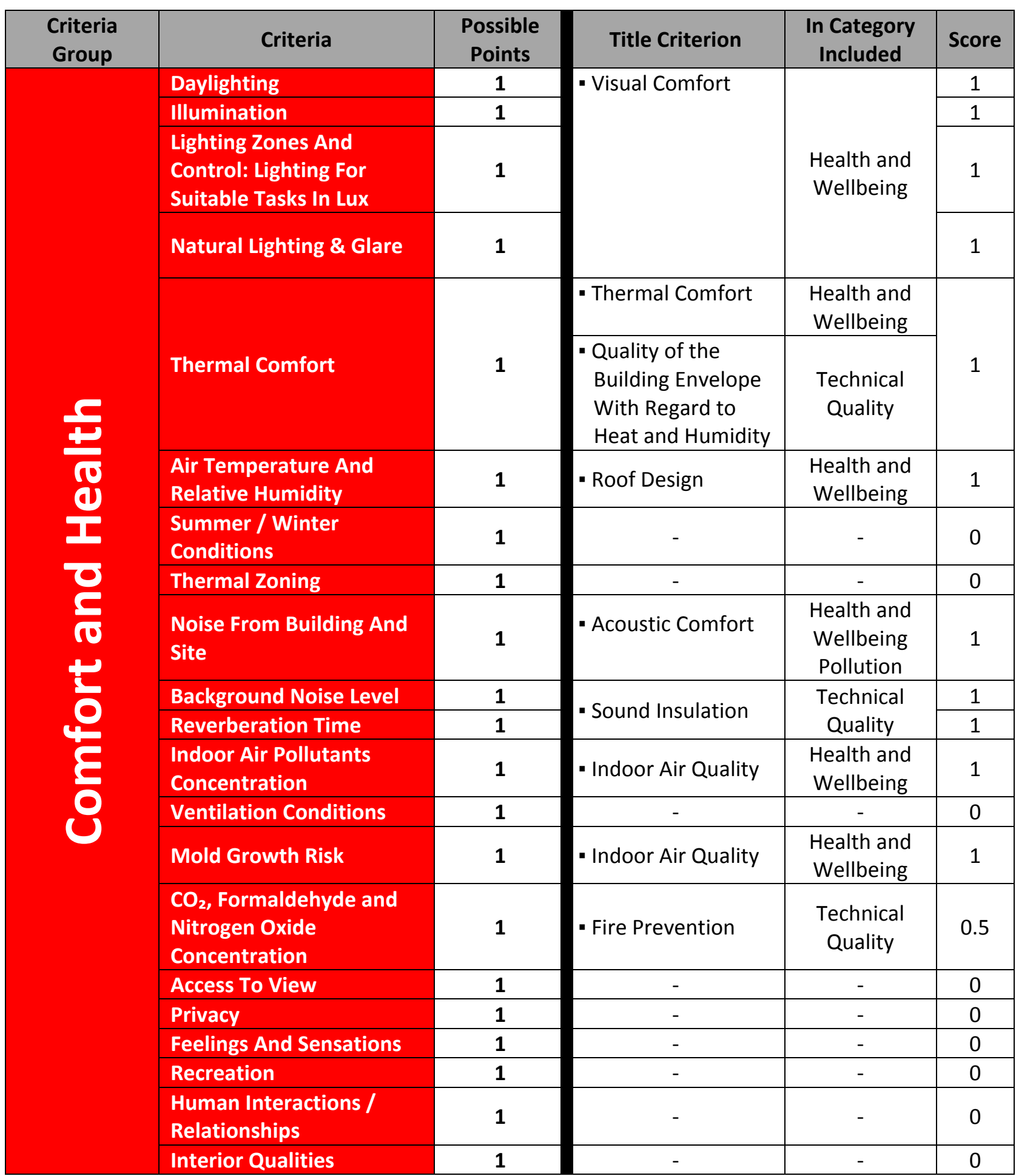




\begin{tabular}{|c|c|c|c|c|c|}
\hline $\begin{array}{l}\text { Criteria } \\
\text { Group }\end{array}$ & Criteria & $\begin{array}{c}\text { Possible } \\
\text { Points }\end{array}$ & Title Criterion & $\begin{array}{l}\text { In Category } \\
\text { Included }\end{array}$ & Score \\
\hline \multirow{6}{*}{ 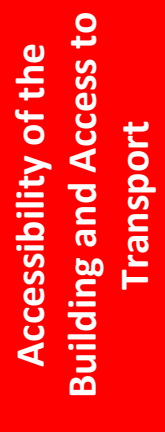 } & Public \& Public & \multirow{2}{*}{1} & - Public Accessibility & Functionality & \multirow{2}{*}{1} \\
\hline & Transport Accessibility & & $\begin{array}{l}\text { - Transport } \\
\text { Accessibility }\end{array}$ & $\begin{array}{l}\text { Quality of } \\
\text { Location }\end{array}$ & \\
\hline & $\begin{array}{l}\text { Barrier-Free } \\
\text { Accessibility }\end{array}$ & 1 & $\begin{array}{l}\text { - Barrier-Free } \\
\text { Accessibility }\end{array}$ & Functionality & 1 \\
\hline & Bicycle Comfort & 1 & - Bicycle Comfort & Functionality & 1 \\
\hline & Pedestrian Comfort & 1 & - & - & 0 \\
\hline & Car Parking Capacity & 1 & - & - & 0 \\
\hline
\end{tabular}

\begin{tabular}{|c|c|c|c|c|c|}
\hline $\begin{array}{l}\text { Criteria } \\
\text { Group }\end{array}$ & Criteria & $\begin{array}{l}\text { Possible } \\
\text { Points }\end{array}$ & Title Criterion & $\begin{array}{l}\text { In Category } \\
\text { Included }\end{array}$ & Score \\
\hline \multirow{7}{*}{ 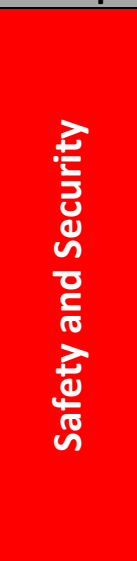 } & Safety Assessment & 1 & \multirow{2}{*}{$\begin{array}{l}\text { - Safety and Risk of } \\
\text { Incidents }\end{array}$} & \multirow{2}{*}{$\begin{array}{l}\text { Health and } \\
\text { Wellbeing }\end{array}$} & 1 \\
\hline & Safety Management & 1 & & & 1 \\
\hline & Site And Building & 1 & - Emission Control & $\begin{array}{c}\text { Technical } \\
\text { Quality }\end{array}$ & 1 \\
\hline & Combustion Sources & 1 & - Fire Prevention & $\begin{array}{c}\text { Technical } \\
\text { Quality }\end{array}$ & 1 \\
\hline & $\begin{array}{l}\text { Resistance - Storm, } \\
\text { High Water }\end{array}$ & 1 & - & - & 0 \\
\hline & Resistance - Hail & 1 & - & - & 0 \\
\hline & $\begin{array}{l}\text { Resistance - } \\
\text { Earthquake }\end{array}$ & 1 & - & - & 0 \\
\hline
\end{tabular}

\begin{tabular}{|c|c|c|c|c|c|}
\hline $\begin{array}{c}\text { Criteria } \\
\text { Group }\end{array}$ & Criteria & $\begin{array}{c}\text { Possible } \\
\text { Points }\end{array}$ & Title Criterion & $\begin{array}{l}\text { In Category } \\
\text { Included }\end{array}$ & Score \\
\hline \multirow{4}{*}{ \pm} & Infrastructure & 0.5 & $\begin{array}{l}\text { - Proximity to } \\
\text { Amenities }\end{array}$ & $\begin{array}{l}\text { Quality of } \\
\text { Location }\end{array}$ & 0.5 \\
\hline & Heat Island Effect & 0.5 & - Roof Design & $\begin{array}{l}\text { Health and } \\
\text { Wellbeing }\end{array}$ & 0.5 \\
\hline & Landscape Inputs & 0.5 & - & - & 0 \\
\hline & Risk At The Site & 0.5 & $\begin{array}{l}\text { - Micro } \\
\text { Environment }\end{array}$ & Site Quality & 0.5 \\
\hline
\end{tabular}




\begin{tabular}{|c|c|c|c|c|c|}
\hline $\begin{array}{l}\text { Criteria } \\
\text { Group }\end{array}$ & Criteria & $\begin{array}{l}\text { Possible } \\
\text { Points }\end{array}$ & Title Criterion & $\begin{array}{l}\text { In Category } \\
\text { Included }\end{array}$ & Score \\
\hline \multirow{2}{*}{$\begin{array}{c}\text { Aspects } \\
\text { during } \\
\text { Construction }\end{array}$} & Construction Waste & 0.5 & - & - & 0 \\
\hline & $\begin{array}{l}\text { Construction Indoor Air } \\
\text { Quality }\end{array}$ & 0.5 & - & - & 0 \\
\hline
\end{tabular}

\begin{tabular}{|c|c|c|c|c|c|}
\hline $\begin{array}{l}\text { Criteria } \\
\text { Group }\end{array}$ & Criteria & $\begin{array}{l}\text { Possible } \\
\text { Points }\end{array}$ & Title Criterion & $\begin{array}{l}\text { In Category } \\
\text { Included }\end{array}$ & Score \\
\hline \multirow{5}{*}{ 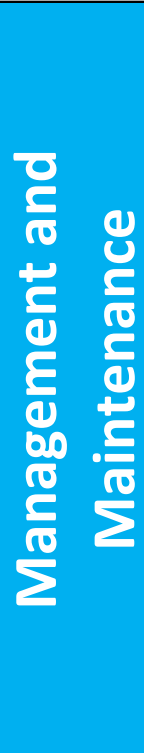 } & $\begin{array}{l}\text { Building User Guide, } \\
\text { Awareness \& Education }\end{array}$ & 0.5 & $\begin{array}{l}\text { - Creation of } \\
\text { Conditions for } \\
\text { Optimal Use and } \\
\text { Management }\end{array}$ & Planning & 0.5 \\
\hline & $\begin{array}{l}\text { Establishing } \\
\text { Preconditions For An } \\
\text { Optimized Use And } \\
\text { Operation }\end{array}$ & 0.5 & - & - & 0 \\
\hline & & & $\begin{array}{l}\text { - Ease of Cleaning } \\
\text { and Maintenance }\end{array}$ & $\begin{array}{c}\text { Technical } \\
\text { Quality }\end{array}$ & \\
\hline & $\begin{array}{l}\text { Maintainability And } \\
\text { Operation Comfort }\end{array}$ & 0.5 & $\begin{array}{l}\text { - Creation of } \\
\text { Conditions for } \\
\text { Optimal Use and } \\
\text { Management }\end{array}$ & Planning & 0.5 \\
\hline & $\begin{array}{l}\text { Intelligence And } \\
\text { Controllability }\end{array}$ & 0.5 & - & - & 0 \\
\hline
\end{tabular}




\begin{tabular}{|c|c|c|c|c|c|}
\hline $\begin{array}{l}\text { Criteria } \\
\text { Group }\end{array}$ & Criteria & $\begin{array}{c}\text { Possible } \\
\text { Points }\end{array}$ & Title Criterion & $\begin{array}{c}\text { In Category } \\
\text { Included }\end{array}$ & Score \\
\hline \multirow{6}{*}{$\begin{array}{l}\frac{2}{0} \\
\frac{0}{0} \\
0 \\
y \\
y \\
0 \\
0 \\
0\end{array}$} & & & - Influence of User & $\begin{array}{l}\text { Health and } \\
\text { Wellbeing }\end{array}$ & \multirow[b]{2}{*}{0.5} \\
\hline & $\begin{array}{l}\text { Integral Planning, } \\
\text { Integrated Design }\end{array}$ & 0.5 & $\begin{array}{l}\text { - Integral Planning } \\
\text { - Evidence Of } \\
\text { Sustainability } \\
\text { During Bid } \\
\text { Invitation And } \\
\text { Awarding }\end{array}$ & Planning & \\
\hline & $\begin{array}{l}\text { Optimization And } \\
\text { Complexity Of The } \\
\text { Planning Approach }\end{array}$ & 0.5 & $\begin{array}{l}\text { - Optimization and } \\
\text { Complexity of } \\
\text { Planning Method }\end{array}$ & Planning & 0.5 \\
\hline & $\begin{array}{l}\text { Quality Of Project's } \\
\text { Preparation }\end{array}$ & 0.5 & $\begin{array}{l}\text { - Quality Of Project } \\
\text { Preparation }\end{array}$ & Planning & 0.5 \\
\hline & $\begin{array}{l}\text { Quality Of The Executing } \\
\text { Contractors / } \\
\text { Prequalification }\end{array}$ & 0.5 & - & - & 0 \\
\hline & $\begin{array}{l}\text { Controlled } \\
\text { Commissioning }\end{array}$ & 0.5 & $\begin{array}{l}\text { - Systematic } \\
\text { Commissioning }\end{array}$ & Construction & 0.5 \\
\hline
\end{tabular}

\begin{tabular}{|c|c|c|c|c|c|}
\hline $\begin{array}{c}\text { Criteria } \\
\text { Group }\end{array}$ & Criteria & $\begin{array}{c}\text { Possible } \\
\text { Points }\end{array}$ & Title Criterion & $\begin{array}{c}\text { In Category } \\
\text { Included }\end{array}$ & Score \\
\hline Innovation & $\begin{array}{l}\text { Innovations, Innovative } \\
\text { Strategies \& Technologies }\end{array}$ & $\mathbf{0 . 5}$ & - & - & 0 \\
\hline
\end{tabular}

\begin{tabular}{|c|c|c|c|c|c|}
\hline $\begin{array}{c}\text { Criteria } \\
\text { Group }\end{array}$ & \multicolumn{1}{|c|}{ Criteria } & $\begin{array}{c}\text { Possible } \\
\text { Points }\end{array}$ & Title Criterion & $\begin{array}{c}\text { In Category } \\
\text { Included }\end{array}$ & Score \\
\hline Usability & $\begin{array}{l}\text { Communications And } \\
\text { Mobility }\end{array}$ & 0.5 & - & - & 0 \\
\hline
\end{tabular}




\begin{tabular}{|c|l|c|c|c|c|}
\hline Criteria Group & \multicolumn{1}{|c|}{ Criteria } & $\begin{array}{c}\text { Possible } \\
\text { Points }\end{array}$ & Title Criterion & $\begin{array}{c}\text { In Category } \\
\text { Included }\end{array}$ & Score \\
\hline \multirow{2}{*}{$\begin{array}{c}\text { Further } \\
\text { Environmental } \\
\text { Criteria }\end{array}$} & Neighboring Buildings & $\mathbf{0 . 2 5}$ & - & - & 0 \\
\cline { 2 - 6 } & $\begin{array}{l}\text { Modular and } \\
\text { Standardized Materials } \\
\text { And Components }\end{array}$ & $\mathbf{0 . 2 5}$ & - & - & 0 \\
\cline { 2 - 6 } & Service Life & $\mathbf{0 . 2 5}$ & - & - & 0 \\
\hline
\end{tabular}

\begin{tabular}{|c|c|c|c|c|c|}
\hline Criteria Group & Criteria & $\begin{array}{l}\text { Possible } \\
\text { Points }\end{array}$ & Title Criterion & $\begin{array}{l}\text { In Category } \\
\text { Included }\end{array}$ & Score \\
\hline \multirow{2}{*}{$\begin{array}{c}\text { Further Indoor } \\
\text { Environmental } \\
\text { Criteria }\end{array}$} & $\begin{array}{l}\text { Electromagnetic } \\
\text { Emissions }\end{array}$ & 0.25 & - & - & 0 \\
\hline & $\begin{array}{l}\text { Indoor Air Quality In } \\
\text { Car Parks }\end{array}$ & 0.25 & - & - & 0 \\
\hline
\end{tabular}

\begin{tabular}{|c|c|c|c|c|c|}
\hline Criteria Group & Criteria & $\begin{array}{l}\text { Possible } \\
\text { Points }\end{array}$ & Title Criterion & $\begin{array}{l}\text { In Category } \\
\text { Included }\end{array}$ & Score \\
\hline \multirow{5}{*}{$\begin{array}{l}\text { Architectural } \\
\text { and Cultural } \\
\text { Considerations }\end{array}$} & $\begin{array}{l}\text { Cultural Heritage } \\
\text { Integration }\end{array}$ & 0.25 & \multirow{2}{*}{$\begin{array}{l}\text { - Artistic Aspects in } \\
\text { Construction }\end{array}$} & \multirow{2}{*}{ Design } & 0.25 \\
\hline & Aesthetic Aspects & 0.25 & & & 0.25 \\
\hline & $\begin{array}{l}\text { Design And Urban } \\
\text { Development }\end{array}$ & 0.25 & $\begin{array}{l}\text { - Method of Urban } \\
\text { and Design } \\
\text { Development } \\
\text { Concept }\end{array}$ & Design & 0.25 \\
\hline & Monument & 0.25 & - & - & 0 \\
\hline & $\begin{array}{l}\text { Branding And External } \\
\text { Expression }\end{array}$ & 0.25 & - & - & 0 \\
\hline
\end{tabular}




\begin{tabular}{|c|l|c|c|c|c|}
\hline Criteria Group & \multicolumn{1}{|c|}{ Criteria } & $\begin{array}{c}\text { Possible } \\
\text { Points }\end{array}$ & Title Criterion & $\begin{array}{c}\text { In Category } \\
\text { Included }\end{array}$ & Score \\
\hline \multirow{2}{*}{} & $\begin{array}{l}\text { Local Employment } \\
\text { Opportunities / Use Of } \\
\text { Local Services }\end{array}$ & $\mathbf{0 . 2 5}$ & - & 0 \\
\cline { 2 - 6 } & $\begin{array}{l}\text { Community Impact } \\
\text { Consultation }\end{array}$ & $\mathbf{0 . 2 5}$ & - & - & 0 \\
\cline { 2 - 6 } & $\begin{array}{l}\text { Responsible And } \\
\text { Ethical Procurement }\end{array}$ & $\mathbf{0 . 2 5}$ & - & - & 0 \\
\cline { 2 - 7 } & Available Services \\
\cline { 2 - 7 } & $\begin{array}{l}\text { Social Cost Benefit } \\
\text { Analysis }\end{array}$ & $\mathbf{0 . 2 5}$ & - & - & 0 \\
\cline { 2 - 7 } & $\begin{array}{l}\text { Considerate } \\
\text { Constructors }\end{array}$ & $\mathbf{0 . 2 5}$ & - & - & 0 \\
\cline { 2 - 7 } & Neighborhood & $\mathbf{0 . 2 5}$ & - & - & 0 \\
\hline
\end{tabular}

\begin{tabular}{|c|l|c|c|c|c|}
\hline Criteria Group & \multicolumn{1}{|c|}{ Criteria } & $\begin{array}{c}\text { Possible } \\
\text { Points }\end{array}$ & \multicolumn{1}{|c|}{ Title Criterion } & $\begin{array}{c}\text { In Category } \\
\text { Included }\end{array}$ & Score \\
\cline { 2 - 6 } & $\begin{array}{l}\text { Choice Of } \\
\text { Construction Process }\end{array}$ & $\mathbf{0 . 2 5}$ & $\begin{array}{l}\text { - Construction Site / } \\
\text { Construction } \\
\text { Process }\end{array}$ & Construction & 0.25 \\
\cline { 2 - 5 } Implementation & $\begin{array}{l}\text { Quality Assurance Of } \\
\text { Construction } \\
\text { Execution }\end{array}$ & $\mathbf{0 . 2 5}$ & $\begin{array}{l}\text { - Quality Assurance } \\
\text { for Construction }\end{array}$ & Construction & 0.25 \\
\cline { 2 - 6 } & $\begin{array}{l}\text { Exemplary } \\
\text { Performance }\end{array}$ & $\mathbf{0 . 2 5}$ & - & - & 0 \\
\hline
\end{tabular}




\section{APPENDIX D}

\begin{tabular}{|c|c|c|}
\hline Environmental issues & Economic issues & Social issues \\
\hline $\begin{array}{ll}\text { - } & \text { Energy } \\
\text { - } & \text { Materials } \\
\text { - } & \text { Climate change } \\
\text { - } & \text { Water use and ecology } \\
\text { - } & \text { Waste }\end{array}$ & $\begin{array}{ll}\text { - } & \text { Management and } \\
\text { - } & \text { Lifecycle costs } \\
\text { - } & \text { Building adaptability } \\
\text { - } & \text { Process quality } \\
\text { - Innovation }\end{array}$ & $\begin{array}{l}\text { - } \text { Comfort and health } \\
\text { - } \text { Accessibility of the } \\
\text { building and access to } \\
\text { transport } \\
\text { - Safety and security }\end{array}$ \\
\hline
\end{tabular}

Partners are: VTT Technical Research Centre of Finland, BRE Global Ltd (UK), Centre Scientifique et Technique du Bâtiment (France), Belgian Building Research Institute, Karlsruhe Institute of Technology (Germany), Faculty of Civil Engineering of the Czech Technical University, Institute for Industrial Engineering Fraunhofer (Germany), Fundación LABEIN (Spain), ÖGUT (Austria), YIT (Finland), VINCI Construction (France), Werner Sobek (Germany), W/E Consultants (Netherlands). 